د/ أحمد عبد القتاح حمدي الهنداوي

إدارة أولويات برنامج الابلوم العام في التربية بجامعة الأزهر في ضوي الهوي

مُدخل المقارنة المرجعية benchmarking "دراسة مستقبلية"

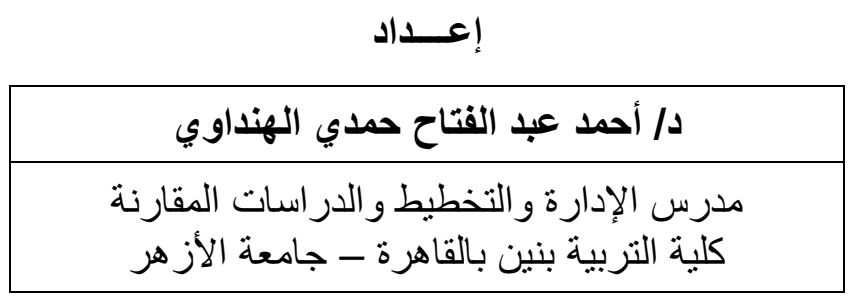

ملخص الاراسة

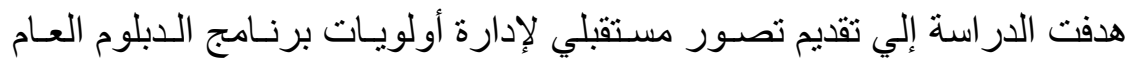

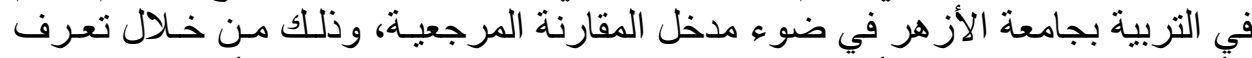

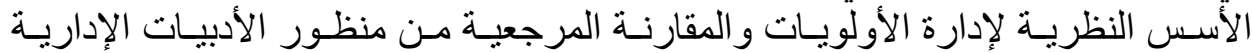

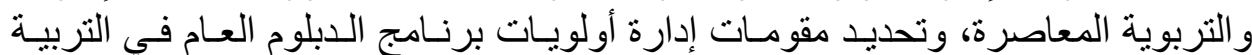

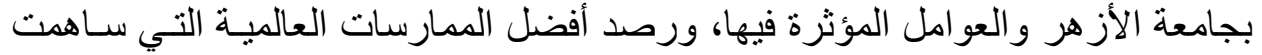

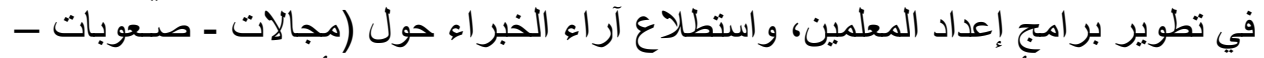

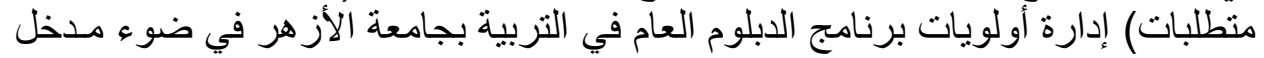

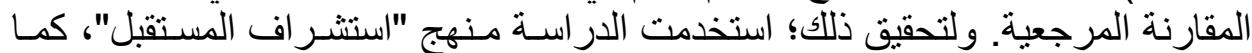

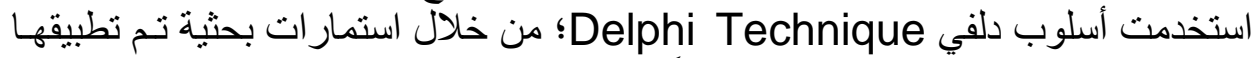

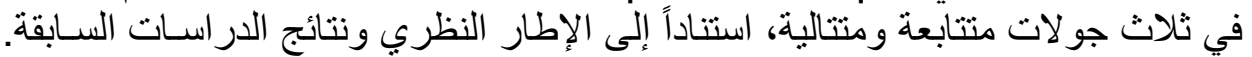

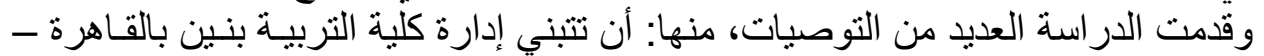

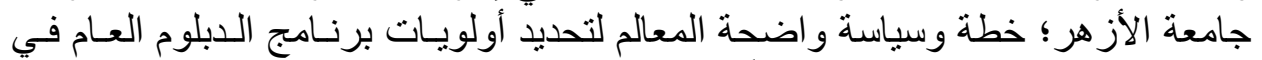

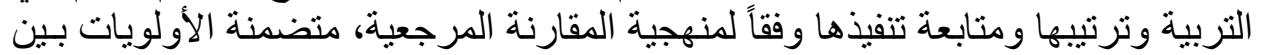

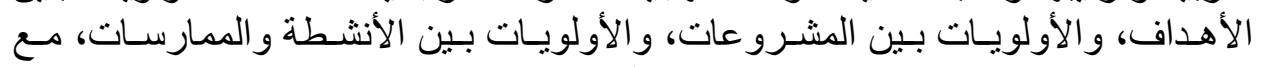

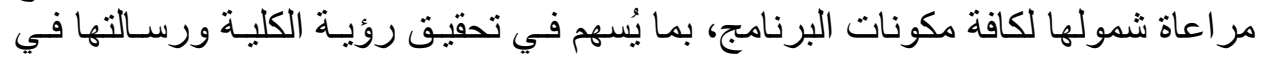
إطار عالمي دينامي منغير.

الكلمات المفتاحية: إدارة الأولويات ـ المقارنة المرجعية ـ أفضل الممارسـات ـالدبلوم

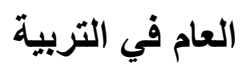

مجلة كلية التربية- جامعة عين شثس 


\section{إدارة أولويات برنامج الدبلوم العام في التربية بجامعة الأزهر في ضوء مدخل المقارنة المرجعية \\ benchmarking}

\section{Abstract}

The study aimed at presenting a future perspective for priorities management of the General Diploma Program in Education at Al-Azhar University based on benchmarking approach, by identifying the theoretical foundations for priorities management and benchmarking approach from the perspective of contemporary administrative and educational literature, determining the elements of priorities management and factors affecting the General Diploma Program in Education at Al-Azhar University, monitoring global best practices that have contributed to the development of teacher training programs, and exploring the experts opinions about (Areas - difficulties - requirements) of priorities management of the General Diploma Program in Education at Al-Azhar University based on benchmarking approach. To do so; The study used the "future foresight" approach, as well as the Delphi technique; Through questionnaire, they were applied in three consecutive rounds, based on the theoretical framework and the results of previous studies. The study came out with several recommendations, including: The faculty should adopt a well-defined plan and a policy, to determine the general diploma in education program priorities, arrange and monitor its implementation according to the benchmarking approach. This plan also should include the priority of goals, enterprises, practices and activities, taking into account their comprehensiveness across all components of the program, thereby contributing to achieving of the vision and mission of the faculty in a dynamic and changing global context.

Key words: priorities management, benchmarking, best practices, General Diploma Program in Education

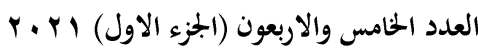

مجلة كلية التربية- جامعة عين شثس 
د/ أحمد عبد الفتاح حمدي الهنداوي

إدارة أولويات برنامج الابلوم العام في التربية بجامعة الأزهر في ضوي الهوي مُخل المقارنة المرجعية benchmarking "دراسة مستقبلية"

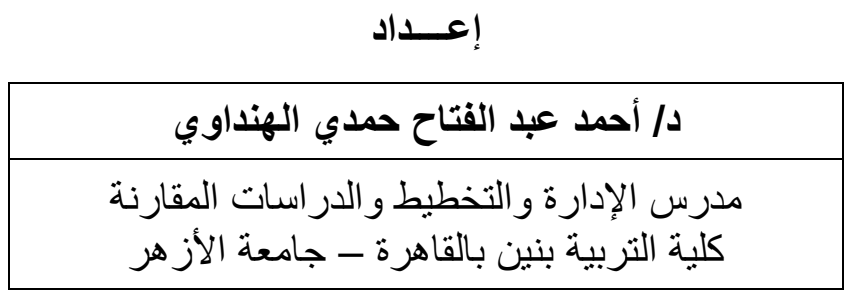

مقدمـة

إن مقدرة أية منظمة على التعلم بصورة أفضل من منافسيها؛ بعد شـرطاً أساسباً

لنجاحها وزيادة مقدرتها على الاستجابة بصـورة مبتكرة للتغيرات البيئيـة، بحثـاًّ عن اسـتر اتيجيات مجربـة فعالـة لتعظيم الاسـتفادة منهـا، وتحقيت الأهداف المنشـودة بـأعلى

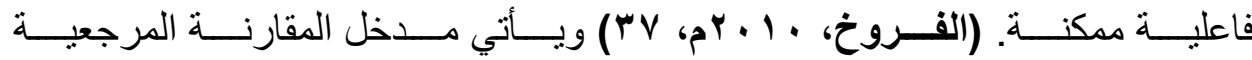
benchmarking اختلاف نشاطاتها، وباعتبار ها أداة للتحسين و البحث عن أفضـل الممارسـات و الأسـاليب، و إيجاد الأفكار و المصادر للتحسين من الداخل والخارج، انطلاقا من الدور الفاعل الذي

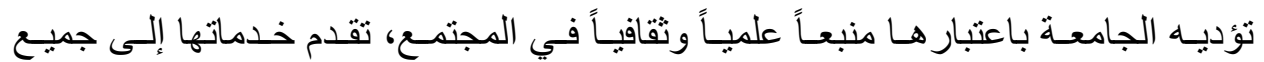
القطاعـات بانفتاحهـا على مؤسسـات المجتمع المحلي وتقويـة الـروابط معهـا. (لطفى و

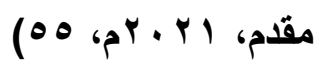

وتُساعد منهجيـة المقارنـة المرجعيـة benchmarking علي تغيير طريقة

التفكير من تقليدي مُنغلق إلي الانفتـاح و التجريبـ، وتكـوين المنهجيـة العلميـة، و التـدريب

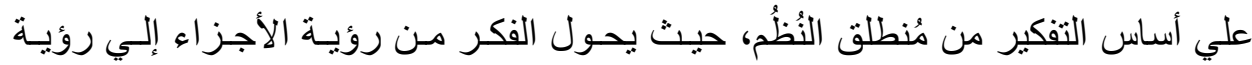

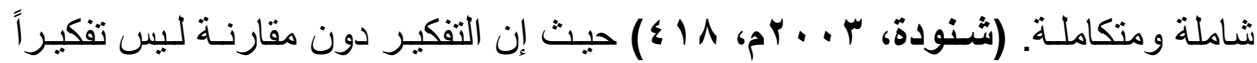
Thinking without comparison is unthinkable

مجلة كلية التربية- جامعة عين شثس 
إدارة أولويات برنامج الدبلوم العام في التربية بجامعة الأزهر في ضوء ملخل المقارنة المرجعية benchmarking

مستمرة، وضرورة حياتية وضرورة فكريـة بـل وضـرورة علميـة؛ تســاعدنا في معرفـة

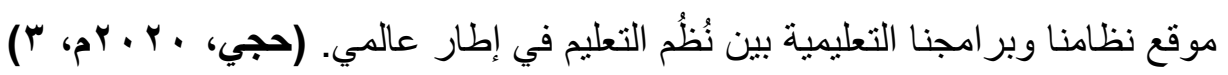
وتجدر الإشارة إلي أن مقارنة الممارسات المتميزة بالجامعات الأخرى لا يعني

استتساخها، بل تطويعها لظـروف الجامعـة المعنيـة، حيث إن تطور الجامعـات المُنافسـة يتو اصل أثناء زمن الئقارنة المرجعية، وبذا قد تستمر الفجوة برغم التحسين، لذا لا ينبغي التوقف عند مو اكبـة تطور الآخـرين وحسب، بـل استهداف التفوق عن طريق نظرة مستقبلية مستهدفة الأفضل، ووفقاً لهذه الرؤيـة؛ يعنـي بالمقارنـة المرجعيـة أنها: وسيلة للتغيير الإيجابي عبر نظرة خارجية تقود إلي تحسينات داخلية، وذللك عن طريق محاولـة

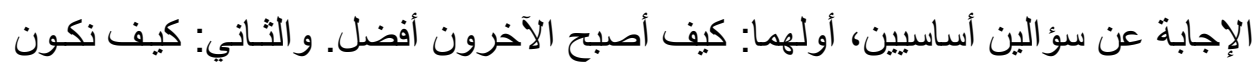

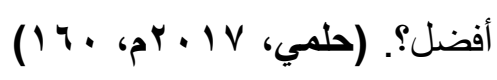

وتحتل قضية "إعداد المعلمين" بالمؤسسات الجامعيـة أولويـة خاصــة في الوقت الحاضر، لأنها قضية التربية نفسها؛ حيث إنها تحدد طبيعة ونوعية الدور الذي يقوم بـه المعلم في المؤسسات التربوية من حيث التكوين العلمي و التقافي لفكر طلابـه، و التشكيل

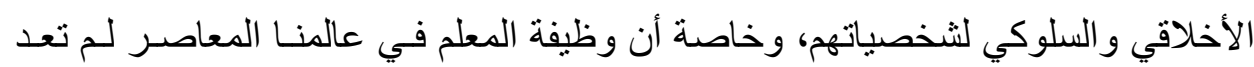

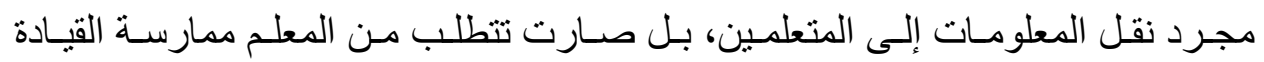
و البحث و التقصي، كما يواجه توسعاً هائلاً في حجم المعرفـة الإنسـانية، ومسن هنـا يمكن

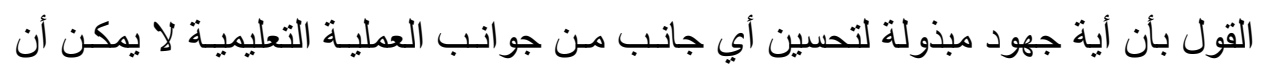

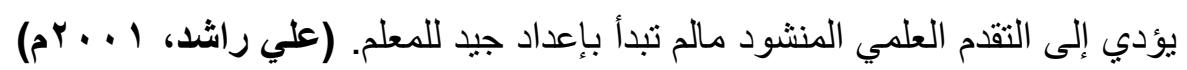
وبناء عليه؛ فقد أصبح تطوير برامج إعداد المعلمين ومر اجعتها وتحديد أولويات تطوير ها عملية مستمرة وموصـولة في كل مكان، ويبقى الأمـر مرهون بقدرة كليـات التربية علي تحويل الرؤى المستقبلية إلي إجراءات تنفيذيـة مـؤثرة في مجريـات الواقع، 


\section{د/ أحمد عبد الفتاح حمدي الهنداوي}

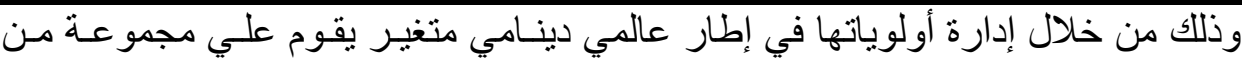
التفـاعلات البينيـة بين أفر اده وظـواهره وأحداتـه، بمـا يُسـهم في إكسـاب الطالب/المعلم المهار ات التعليمية التي تمكنه من ممارسة مهنة التدريس بنجاح.

وتـرتبط إدارة البـر امج الأكاديميـة الجامعيـة بـالكثير مسن المتطلبـات الإداريـة و الفنية، و الالتز ام بأدائها في أوقات محددة، فالعملية الإداريـة عمليـة متشــابكة ومتر ابطـة، وتمثل شبكة من العلاقات التي تعمل معا من أجل بلوغ الأهداف المخططة، حيث إن كل عنصر في المنظومة الجامعيـة لـه دوره الخـاص المـرتبط بغيره مـن الأدوار فهو يؤثر فيها، ويتأثر بها، وعليه فلا مجال في الإدارة إلى العمل الفردي والذاتي، فالعمل الجماعي التعاوني الذي ينظر فيه إلى العملية الإدارية كنظام قائم بذاته تحكمه قنوات اتصـال فعالـة بين عناصر النظام، ويعد (استثمار الوقت وترتيب الأولويات) هنا قضية جديرة بالاهتمـام و العناية، لأهميتها وكونها عامل رئيس في نجاح أي جهد بشري، وتحقيق أهداف الأفر اد

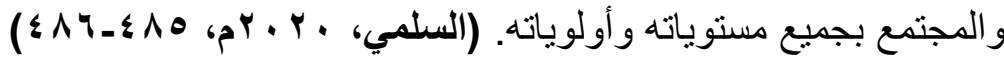

ومن هُنا تبدو إثكالية إدارة أولويـات بـر امج إعداد المعلمين، فهي تقوم أحيانـاً علي تناقض بين ما تحمله من فكر وتقنيات تقليديـة وبين تغيـرات وتحديات بيئيـة ينبغـي استيعابها والاستعداد و الاستجابة لها بصورة غير تقليدية، بما يُساعد علي وضوح الرؤيـة الإصلاحية المنشودة في أذهان كافة المسئولين و المشاركين في تطوير العمليـة التعليميـة، ويـعكس إيجابـاً على تخطيط وتتفيذ وتقيـيم الإصـلاحات الحاليـة، وترفـع مـن مسـتوى

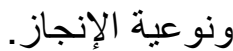

ويعد برنامج الدبلوم العام في التربية بجامعة الأزهر من البر امج الأكاديمية التي تختص بإعداد المعلم المسلم الذى يجمع بين الثقافة التخصصية و الدراسـة الدينيـة، والتي يتميز بها عن زملائسه مـن خريجـي كليـة التربيـة بالـجامعات الأخرى، وتوجيـه العلوم

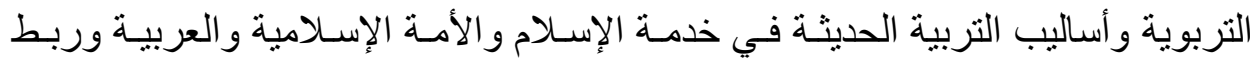


إدارة أولويات برنامج الدبلوم العام في التربية بجامعة الأزهر في ضوء مدخل المقارنة المرجعية benchmarking

الدين بالحياة، انطلاقاً من أن المعلم هو محور العملية التعليمية و المؤثر فيها، وفى تحقيق

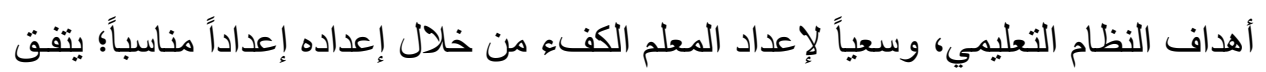
مع التطور ات المستحدثة بحيث يكون قادرا على مواجهة هذه التحديات. (كليـة التربيـة،

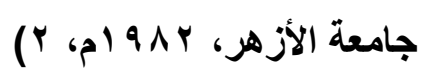

وفي إطار ما سبق فإن هذه الدراسة تعالج قضية إدارة أولويـات برنـامج الدبلوم

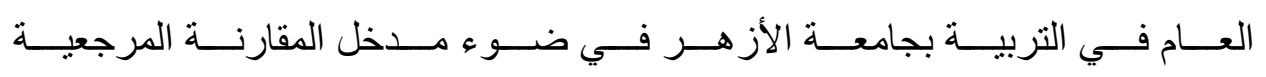

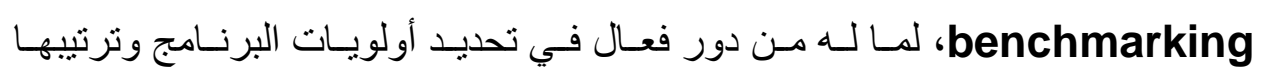

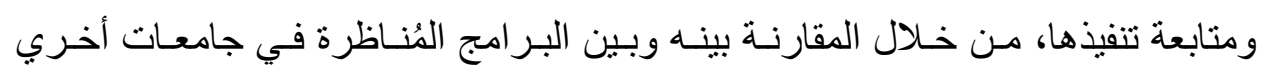

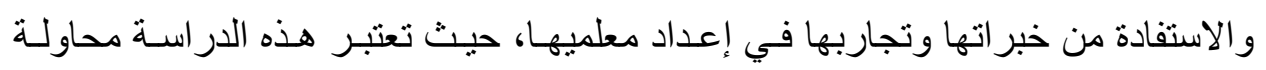

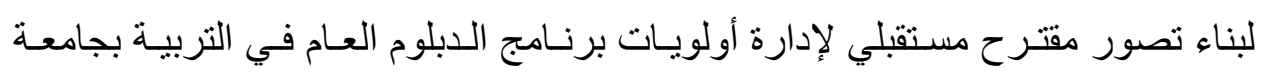
الأزهر في ضوء مدخل المقارنة المرجعية بما يساهم في تتمية قدراته التنافسية.

مشكلة الدراسة

تتطلُع جامعة الأزهر - في رؤيتها المستقبلية- إلى تعزيز دور هـا الر ائد عالميـاً

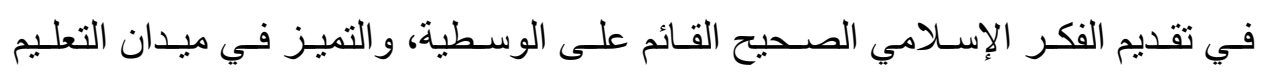

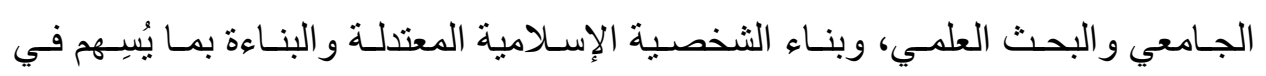

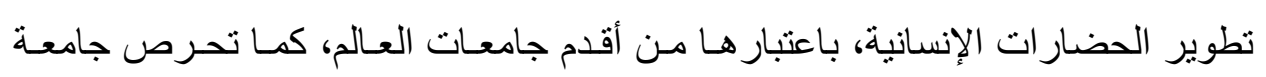

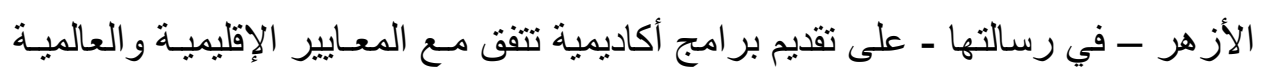

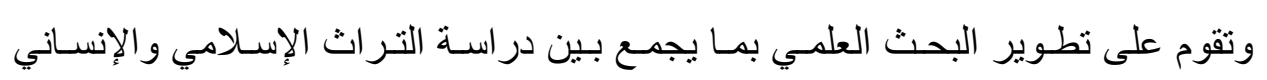

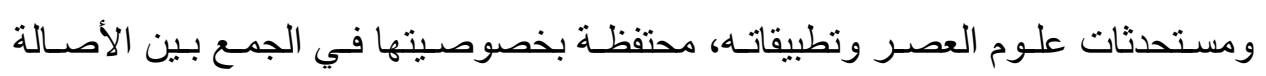

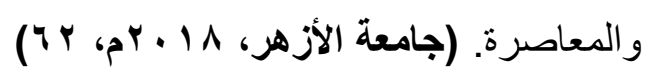




\section{د/ أحمد عبد الفتاح حمدي الهنداوي}

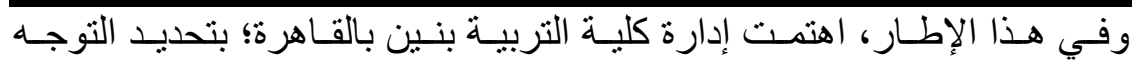

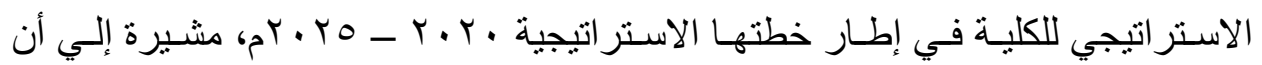

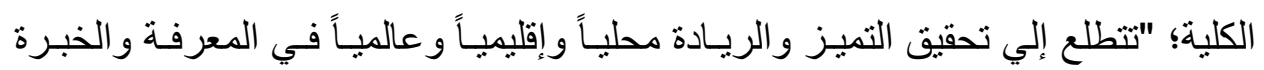
التربوية والتتمية المستدامة في إطار عالميـة رسـالة الأزهـر الثـريف"، كمـا تسـى إلـي ولي "إعداد المعلم المسلم الذى يجمع بين الثقافة التخصصية والدراسة الدينية، والتي يتميز بها عن زملائسه مـن خريجـي كليـة التربيـة بالـجامعات الأخـرى، وتوجيـه العلـوم التربويـة

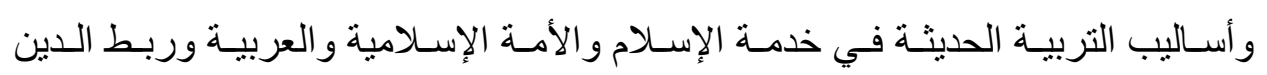
بالحياة، وذلك في ظل عالمية رسالة الأزهر الثريف؛ فالمتعلم الجامعي الأزهري يؤدى ولإسه رسالته في إطار عالمي"، وذلك من خلال العديد مـن الأهداف الاستر اتيجية، والتي مـن

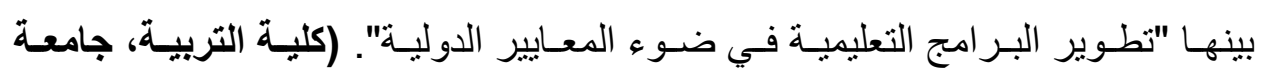

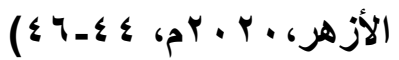

ولا شك أن اهتمـام إدارة كليـة التربيـة بنـين بالقـاهرة - جامعـة الأزهـر بتحقيق

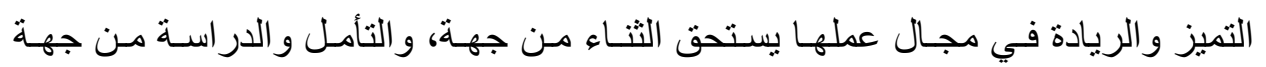

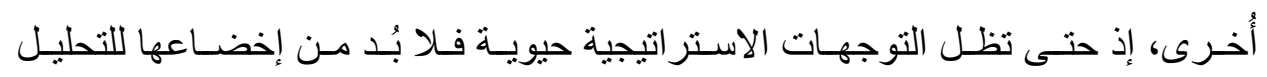
و المر اجعة المستمرة، بشكل يكفل قدرتها على مواكبـة التغيرات المنسـار عة في التعليم

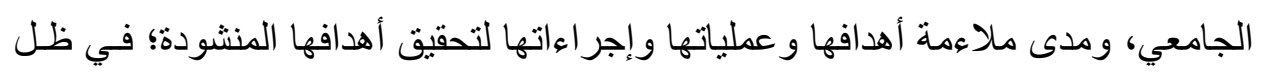
التوجه العالمي و المحلي نحو الريادة الأكاديمية و المشاركة في التصـنيفات الدوليـة لجودة التعليم.

وقد بدأ إحساس الباحث بمشكلة الدراسة؛ من خلال عمله مديراً لمركز التأهيل

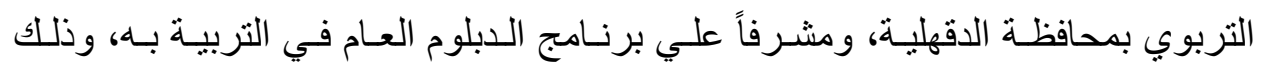

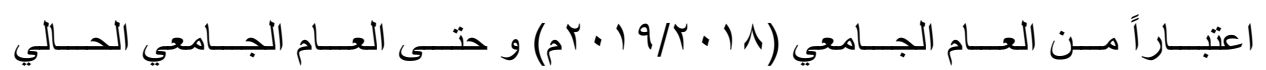

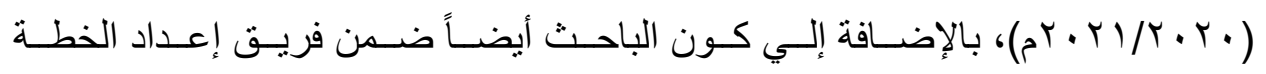

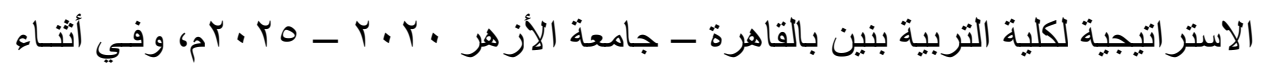

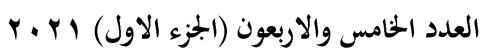

مجلة كلية التربية- جامعة عين شمس 
إدارة أولويات برنامج الابلوم العام في التربية بجامعة الأزهر في ضوء ملخل المقارنة المرجعية benchmarking

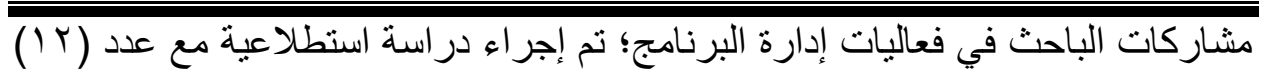

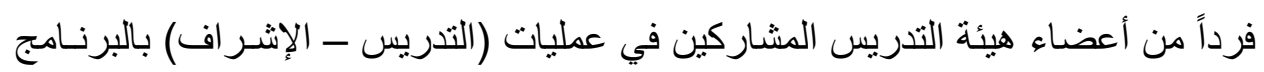

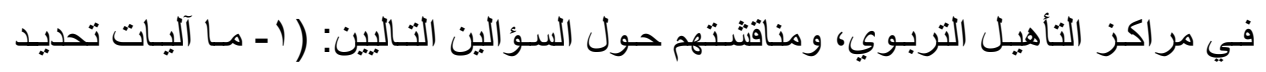

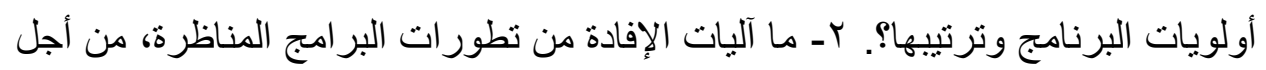

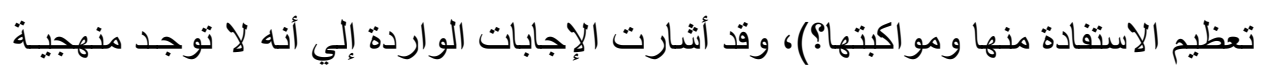

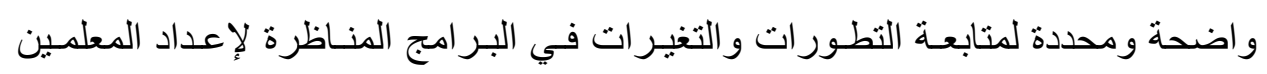

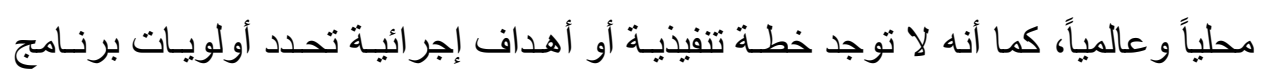
الدبلوم العام في التربية وترتيبها بوضوح في إطار الخطة الاستر اتيجية للكلية. ولا شكك أن وجود منهجية واضحة ومحددة لإدارة أولويات برنامج الدبلوم العسام

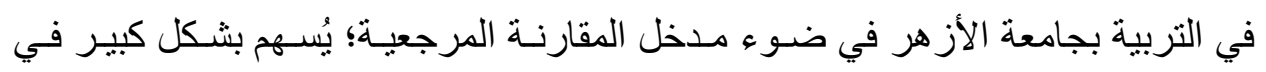

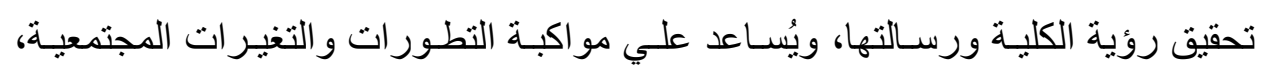

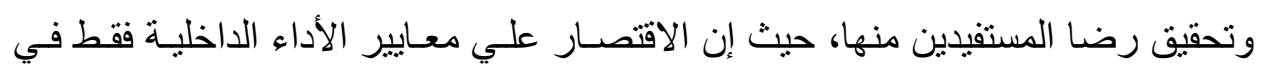
قياس وتطوير جودة أداء البرنامج؛ دون الأخذ بعين الاعتبار معرفة مستوى أدائه بالنسبة النبة

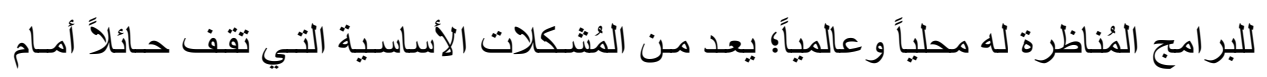
تحقيق ميزته التنافسية.

وتأسيساً على ما سبق؛ يُمكن صياغة مشكلة الدراسة في السؤال الرئيس الآتي: ل كيف يُمكن إدارة أولويات برنامج الدبلوم العام في التربية بجامعة الأزهر في ضـوء مدخل المقارنة المرجعية؟

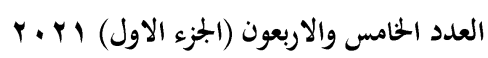

(22)

مجلة كلية التربية- جامعة عين شمس 
ا. ـ مـا الأسـس النظريـة لإدارة الأولويـات والمقارنـة المرجعيـة مـن منظـور الأدبيـات

الإدارية و التربوية المعاصرة؟

Y. مـا المقومـات الأساسـية لإدارة أولويـات برنـامج الــبلوم العـام في التربيـة بجامعـة

الأزهر و العوامل المؤثرة فيها؟

r. ما أفضل الممارسات العالمية التي ساهمت في تطوير بر امج إعداد المعلمين؟

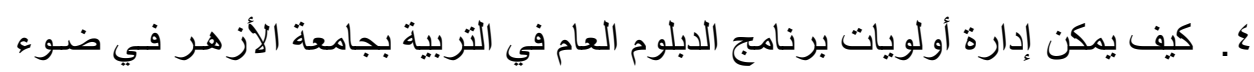
مدخل المقارنة المرجعية من وجهة نظر الخبر اء؟ ๑. ما التصور المستقبلي لإدارة أولويات برنامج الدبلوم العام في التربية بجامعة الأزهـر

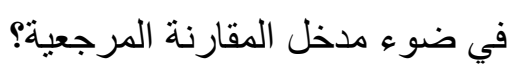

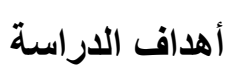

هدفت الدراسة إلي تقديم تصـور مستقبلي لإدارة أولويـات برنسامج الدبلوم العـام

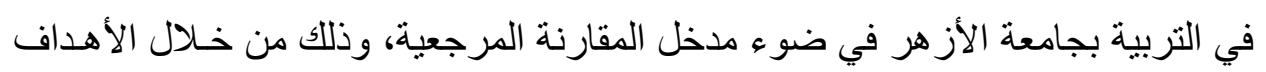

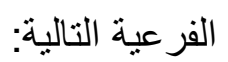

- تعرف الأسس النظرية لإدارة الأولويات و المقارنـة المرجعيـة مـن منظور الأدبيـات الإدارية و التربوية المعاصرة.

تحديد المقومات الأساسية لإدارة أولويات برنـامج الدبلوم العـام في التربيـة بجامعـة الأزهر و العوامل المؤثرة فيها. - رصد أفضل الممارسات العالمية التي ساهمت في تطوير برامج إعداد المعلمين.

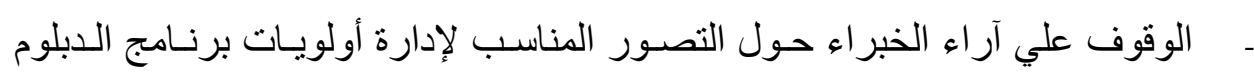
العام في التربية بجامعة الأزهر في ضوء مدخل المقارنة المرجعية. 
إدارة أولويات برنامج الدبلوم العام في التربية بجامعة الأزهر في ضوء مدخل المقارنة المرجعية benchmarking

أهمية الدراسة

تتمثل أهية الدر اسة فيما يلي: - ميل - قد تفيد هذه الدراسة في توجيه جهود تطوير برنامج الدبلوم العام في التربيـة بجامعـة

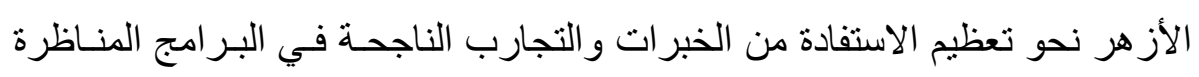
بالجامعات الأخرى ومو اكبة تطور اتها.

- أنها تتماثـي مع التوجهات العالميـة المُعاصـرة نحو الريـادة الأكاديميـة بالمؤسسـات الجامعية و المشاركة في التصنيفات الدولية لجودة التعليم، وتتفق مع كل مـن (الخطـة

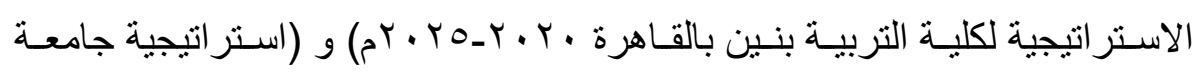

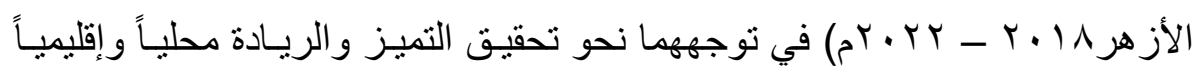
وعالمياً في إطار عالمية رسالة الأزهر الشريف. - قد تقيد المشاركين في إدارة برنـامج الـدبلوم العـام في التربيـة بجامعـة الأزهـر في

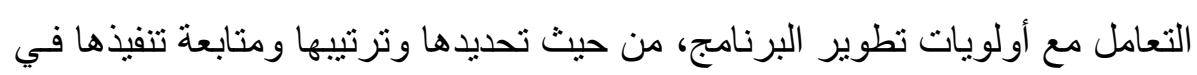
إطار التوجه الاستراتيجي للجامعة.

- قد تفيد المسئولين وصـانعي القرار بالجامعـة في تحديد الخطوات المناسبة لإدارة

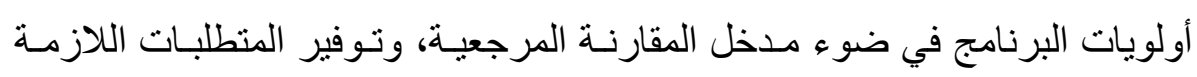

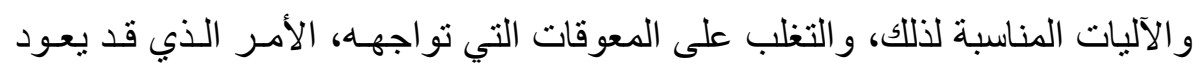
بالنفع على الجامعة من جهة، ويدعم وظيفتها في خدمة المجتمع من جهة أخرى. 


\section{Priorities Management إدارة الأولويات}

تتعـد وتتــوع تعريفـات إدارة الأولويـات، حيـث ورد في در اسـة (الثــافعي،

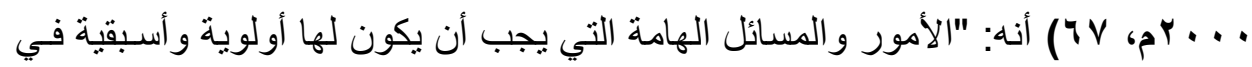
التعامل معها و الاهتمام بها، وتقديمها علي غير ها مـن الأمسور كمرتبـة أولى، وجعـل مـا عداها في مرتبـة تاليـة، سـواء مـن حيـ المسـاحة الزمنيـة المتاحسة ووضـعها في بدايـة الجدول الزمني للأعمال المطلوب إنجاز ها نظر اً لأهميـة وحيويـة عنصـر الوقت بالنسبة لها، أو من حيث إعطاء أولوية التعامل للأمور ذات الأهمية الخاصة و التي يترتب علبي عدم إنمامها حدوث أزمة، مع ضرورة تقديمها علي غير ها".

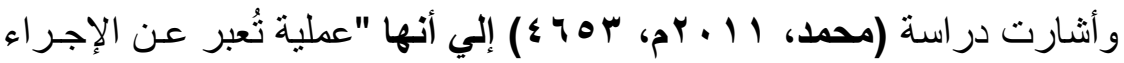
العلمي المُناسب لإحداث التو ازن بين النقص في المـوارد وتعدد الاحتياجـات و البر امج المُلائمة التي يتم الئفاضلة بينها، وذلك وفق القواعد التي يتم الاتفـاق عليها، وتتضـمن مجموعة من العناصر أو التساؤلات التي تتمثل في (من المسئول عن تحديد الأولويـات ـ وما هو الأسلوب المُتبع عند تحديد الأولويـات ـ ومـا تلك العوامـل التـي تـؤثر عليهـا علاوة علي الصعوبات التي قد تواجهها)؟". ويرى (ستيفن ر. كوفي وآخرون، V · . Fم) أن إدارة الأولويات تعني: "تنظيم الوقت لإنجاز (المهم من الأشياء) أكثر من تلك (المستعجلة)، و الأشياء المجهدة أكثر مـن لهن الأشياء البسيطة، من خـلال الاستعانة بمبـدأ ثابـت يستمد قو اعده مـن خبرات وتجـارب أجيال بغرض تـوفير أفضـل السبل لتحسين ورفع مستوى الإنجـاز ، و إدارة الأولويـات

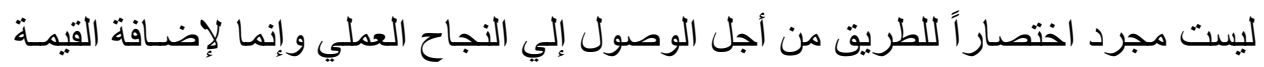
بعيداً عن الخضوع لسيطرة الوقت". 
إدارة أولويات برنامج الدبلوم العام في التربية بجامعة الأزهر في ضوء مدخل المقارنة المرجعية benchmarking

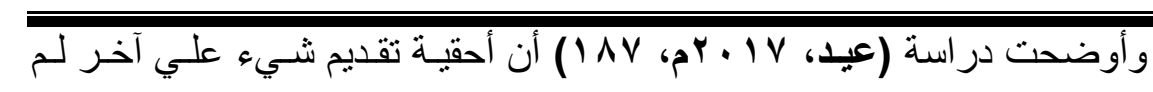

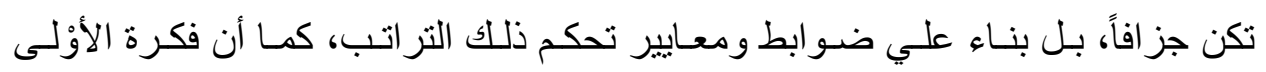

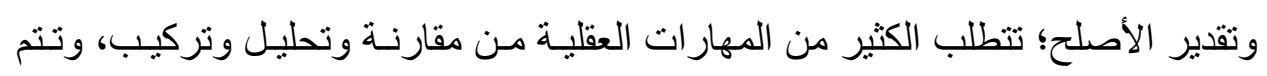

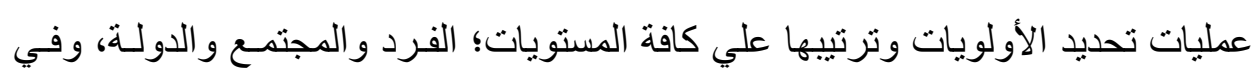

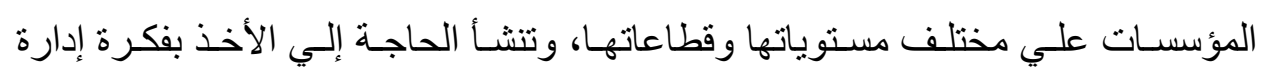

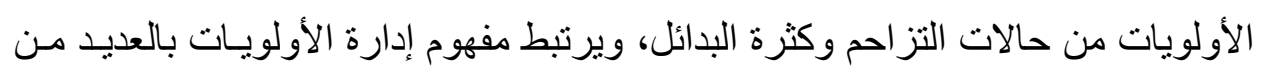

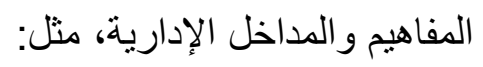
ـ ـ إدارة الوقت، من حيث أن مر اعـاة الأولويـات مـن الأسس الهامـة لاستثتمار الوقت

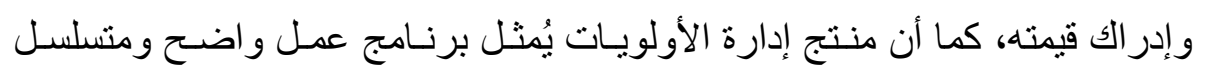
وفق ترتيب زمني معين للتغلب علي مضيعات الوقت.

ـ صنع القرار، و الذي تتضمن عملية البحث عن البدائل التي مـن شـأنها تحقيق هدف

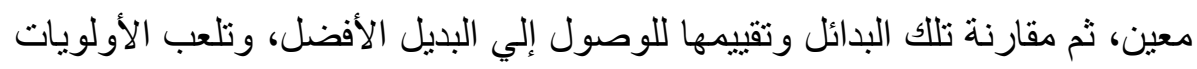

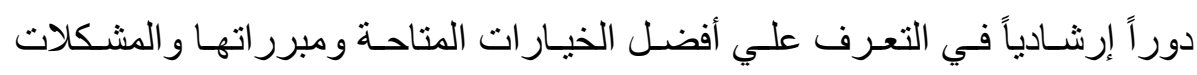

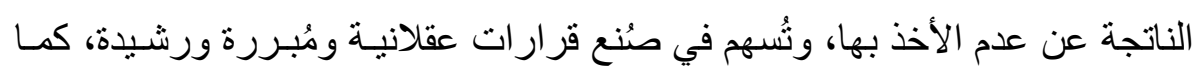
أنها عملية "قيمية" تتضدن عملية مفاضـلة بين بدائل، وترتيب لخيـار ات بنـاء علي في

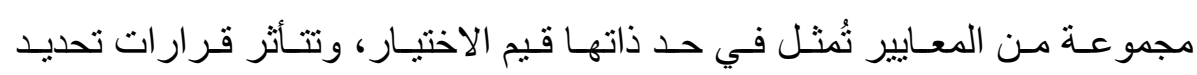
الأولويات بمجمو عة من الاعتبار ات، مثل (الكفاءة ـ الإنصاف ـ الحاجة). - التخطيط، حيث تُشـكل إدارة الأولويـات منهجيـة عمل تُصساحب التخطيط التربـوي

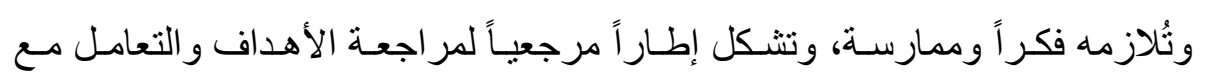

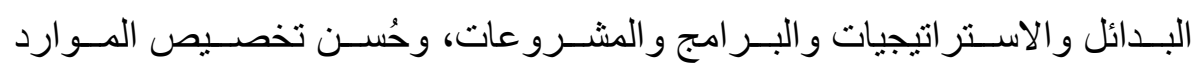
وتوزيعها، ومتابعة تحديث الخطط واستمر اريتها.

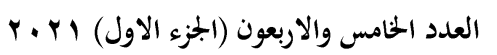

(26)
مجلة كلية التربية- جامعة عين شنم 
د/ أحمد عبد الفتاح حمدي الهنداوي

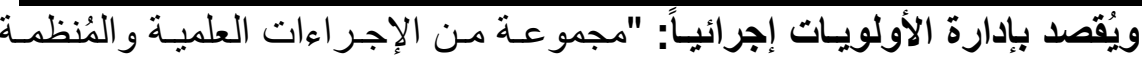

لتحديد درجة الأسبقية أو الأفضلية لأنشطة تطوير برنامج الدبلوم العام في التربيـة بجامعـة التهـة

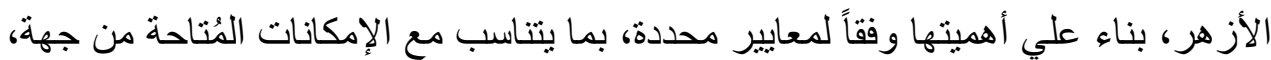
وبما يُسهم في إثباع الاحتياجـات ومواجهة المشكـلات الملحـة من جهة أخرى".

\section{benchmarking المقارنة المرجعية -}

تتعدد وتتنوع تعريفات المقارنـة المرجعيـة، منهـا مـا أنثـارت إليـه در اسـة (عبــ

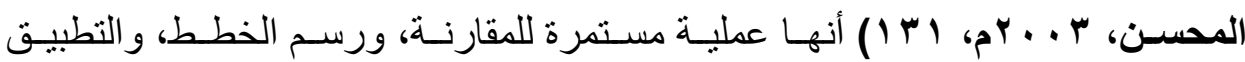
الفعال؛ تتضمن مقارنة المؤسسة وأنشطتها الداخلية بأفضل المؤسسات بغض النظر عن نشاطها، ومقارنة أداء العمليات المختلفة بالمؤسسة مع العمليات المتميزة في المؤسسـات الأخرى بهدف الوصـول إلـي أفضـل قيمـة، ومقارنـة أنـواع مختلفـة مـن أسـاليب تحسـين الأداء لاختيار الأسلوب ذات القيمة الأفضل و المناسب للتطبيق وفقاً لظروف كل مؤسسـة

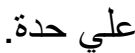

ويـري كل مـن (Woodhouse \& Stella, 2006, 5) أنها تعنـي؛

المقارنة بين البيانات المُتاحة عن المؤسسات الجامعية، من خلال عمليـة مُخططـة، تُركز علي الاسـتثمار الجيــ للوقت في مُعالجـة البيانـات المؤسسية، وتجميعهـا واسـتخدامها، و التأكد مـن مسـتوى الأداء المؤسسـي ومقارنتـه بـأداء مؤسســة جامعيـة أخـرى متميـزة. و أثـارت در اسـة (Adebanjo, et all , 2010, 1140-1142) إلي أنها مقارنـة أداء منظمة بأداء منظمة أخرى منميزة، باعتبار ذلك جزء مـن الجهود المبذولـة لتحسين كفاءة المتابعة و التقييم في دورة السياسات في المنظمـة وتكـون المقارنـة المرجعيـة مفيدة في ثلاث مجالات، أولها: المساهمة في تحسين النتائج، وثانيها: تساعد في تقيبم معقوليـة الأهداف التي تم تحديدها، وثالثها: تسـاهم في تحديد المجموعـات اللاستنتائية التي لها تأثثير إيجابي أو سلبي على عوامل الأداء.

العدد الخامس والاربعون (الجزء الاول) ا Y r r

مجلة كلية التربية- جامعة عين شمس 
إدارة أولويات برنامج الدبلوم العام في التربية بجامعة الأزهر في ضوء مدخل المقارنة المرجعية benchmarking

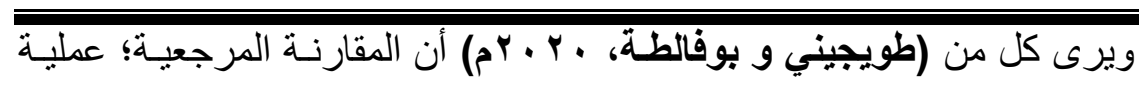

مستمرة ودائمة، بحيث لا تتم أو تحدث في وقت واحد، بل على فترة مـن الزمن، عـلاوة على ذلك هي تهتم بتقييم الأداء الذي يقوم على معايير مشتقة من الأنشطة المر اد تقويمها،

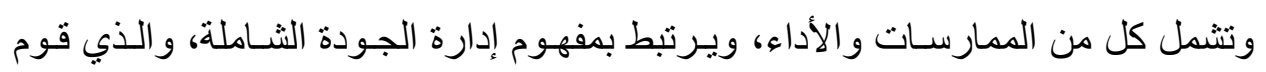

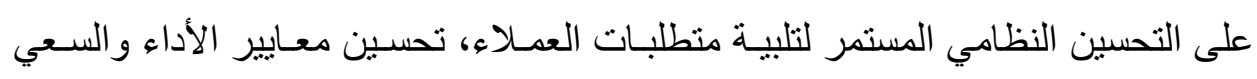
لتحقيق الأفضل دائما بشكل عام.

ويُقصــ بالمقارنــة المرجعيـة إجرائيـاً: "منهجيـة علميـة تتضـمن مجموعـة مـن

الإجر اءات و الأنشطة المستمرة للبحث عن أفضل الممارسات و الأساليب في بر امج إعداد

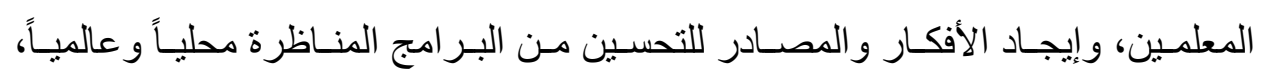

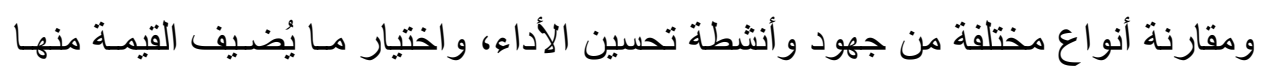

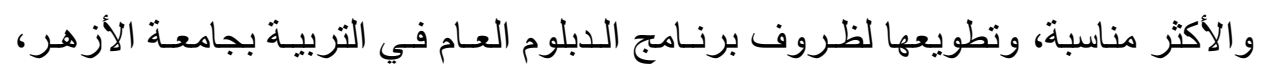
بهذف تحقيق ميزته التنافسية".

\section{منهج الاراسة وأداتها}

استخدمت الدراسة الحالية منهج "استثـراف المستقبل" و الذبي يتضـمن عمليـة

فحص منهجي منظٍٍ للمستقبلِ، بشكلٍ يُؤكدُ النظرَ إلى القـادم بنظـرة ثاقبـة، بغيـةَ تصـورِ

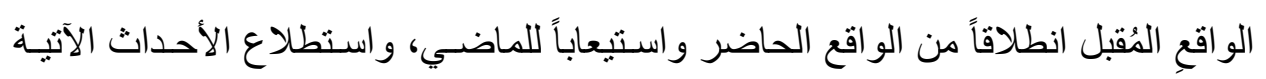

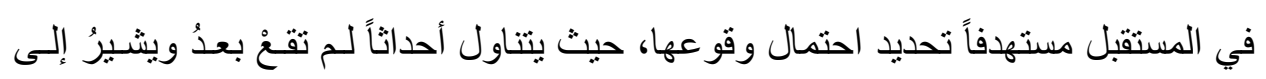

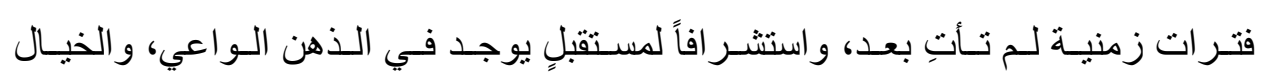

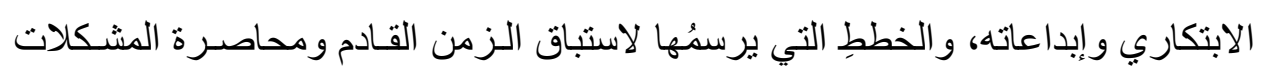

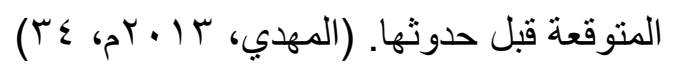

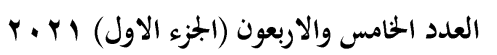

(28)
مجلة كلية التربية- جامعة عين شثس 
د/ أحمد عبد الفتاح حمدي الهنداوي

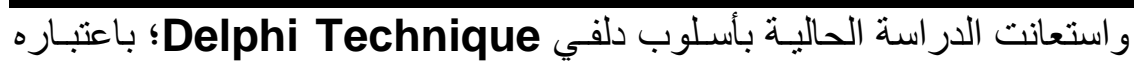

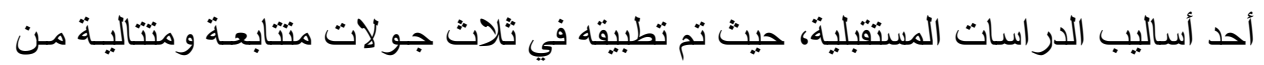

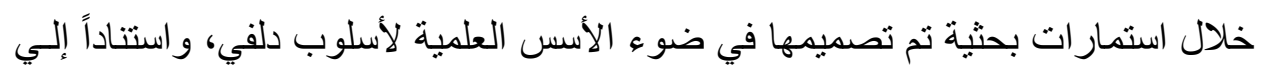

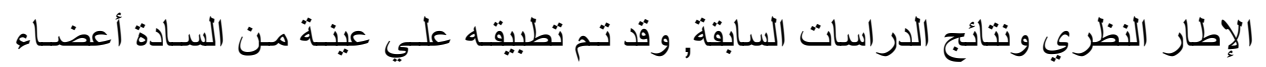
هيئة التدريس ممن لهم علاقة بالبرنامج في الجوانب (القياديـة أو الإشـر افية أو البحثيـة) بالإضافة إلي الخبرة التدريسية في الفترة الحالية بالبرنامج، وذلك من أجل الحصول على لهى إجماع في الـراي بينهم حول: "تقديم تصـور مستقبلي مناسـب لإدارة أولويـات برنـامج الدبلوم العام في التربية بجامعة الأزهر في ضوء هـ مدخل المقارنة المرجعية".

و اتسـاقاً مـع أهـداف الدر اسـة، وطبقـاً للمنهجيـة المتبعـة؛ فتسـير الدراسـة وفقـاً للمحاور التالية: - n

أولاً: إدارة الأولويات والمقارنة المرجعية بالمؤسسات الجامعية "منطقات تظرية" تشكل "إدارة الأولويات" منهجية عمل لها مداخلها وأسالييها ومر احلها التي تمر بها، وتتطلب مشاركة فئات عديدة، في سبيل تحديد وترتيب أولويـات التطسوير و التحسين

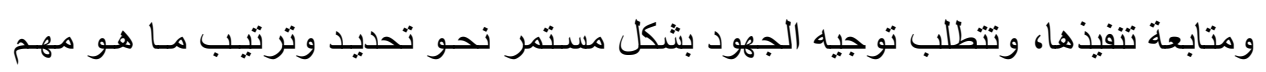
(ماذا نقدم وماذا نؤخر؟ وكيف تسير جهود الإصلاح؟ لكي يصل المستفيدون منها إلي مـا يريدون) في إطار رؤية شاملة ومتكاملة لتحقيق الجودة و التميز.

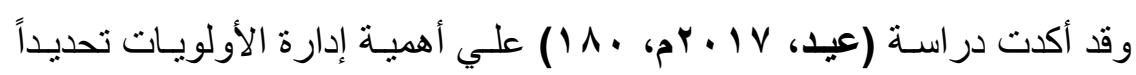

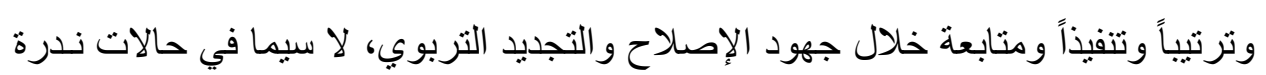

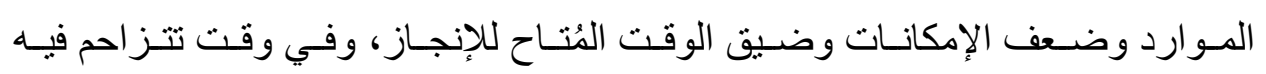

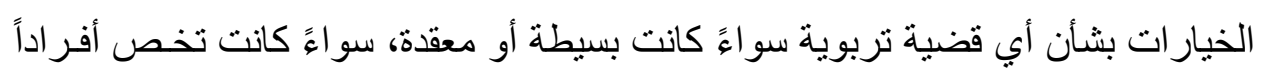

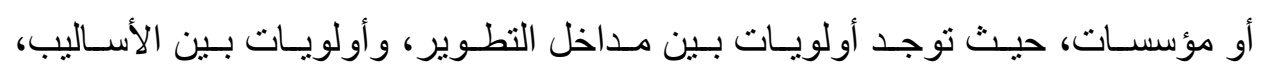

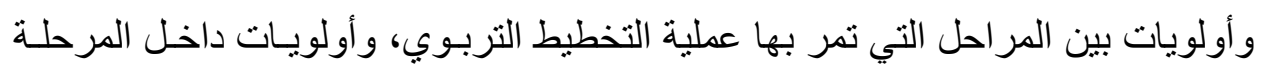


إدارة أولويات برنامج الدبلوم العام في التربية بجامعة الأزهر في ضوء مدخل المقارنة المرجعية benchmarking

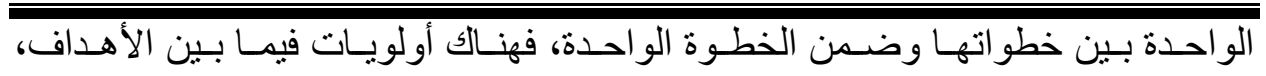
و أولويـات فيمـا بين الاسـتر اتيجيات، وأولويـات فيمـا بين البر امج، و أولويـات فيمـا بـين المشرو عات، وأولويات فيما بين الأنشطة.

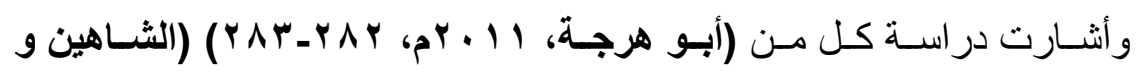

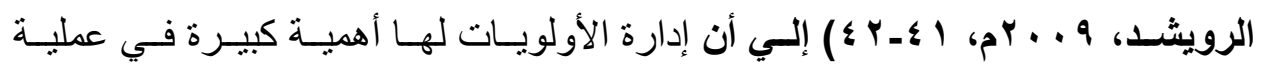

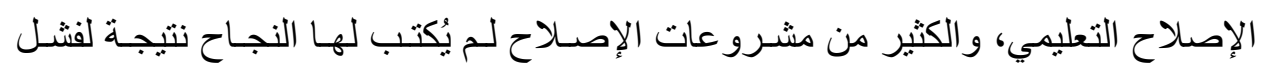

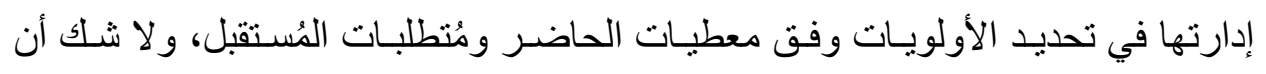

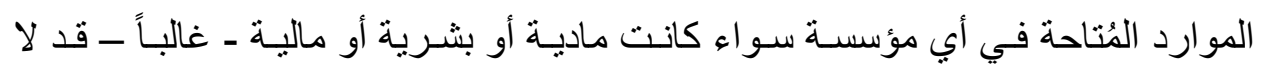
تسمح بتنفيذ جميع الأهداف أو البرامج المطلوبة، الأمـر الذي يتطلب إدراجه الأهداف أو بئريه

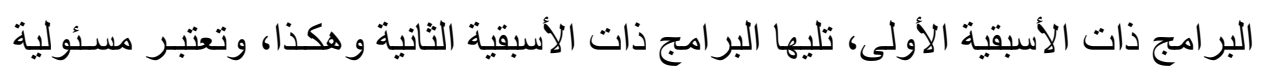

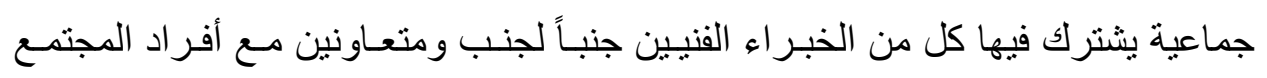
و القيادات التعليمية، سعياً لتحقيق التوازن و التنسيق بين الحاجـات و المشكلات المجتمعيـة

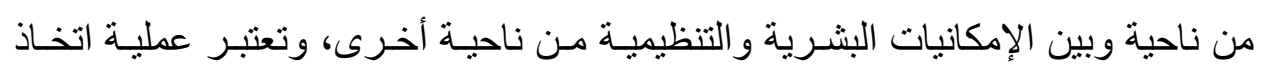

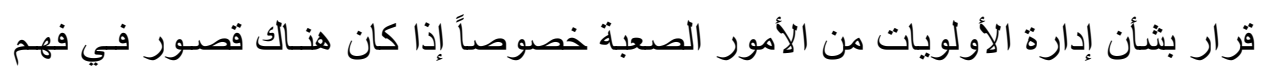

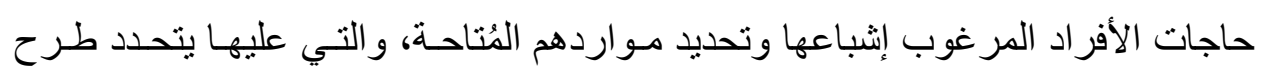
أساليب إثباعها.

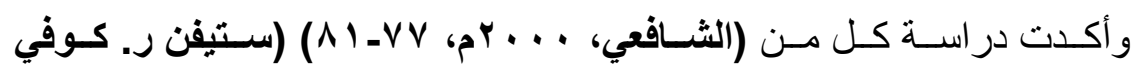

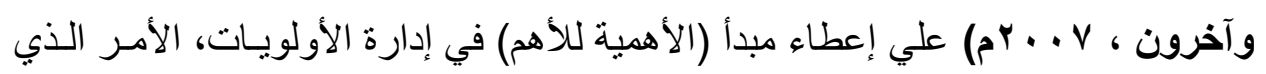

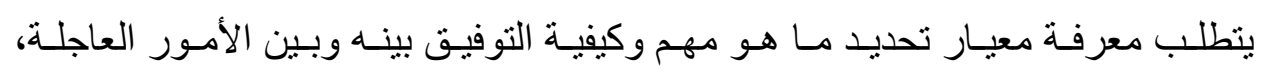

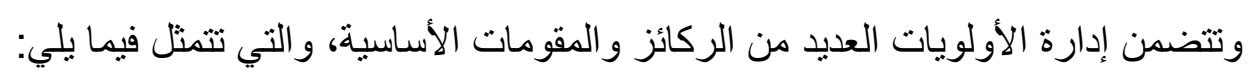

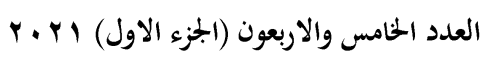

(30)

مجلة كلية التربية- جامعة عين شمس 


\section{د/ أحمد عبد الفتاح حمدي الهنداوي}

تحديد التوجـه المستقبلي: فالمنظمـات التي لـيها رؤيـة مستقبلية و اضـحة و إدر الك أك لرسالتها و أهدافها، و التزام بقيمها ومبادئها، تتفوق علي غير هـا وتكون أكثر قدرة علي مواجهة التحديات و المنافسات، و إذا كانت الرؤية قاصرة؛ فإن الاختبـار لن يقع

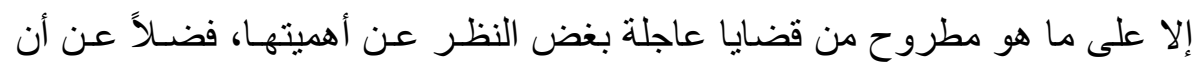
قصور الرؤية وعدم شـولها يؤدي إلـي قصـور الإدراك الفعلي للخيـار ات الأخرى دون وجود توازن بين الحاجات المختلفة وبالتالي تكون الأولويات غير متوازنة، و لا

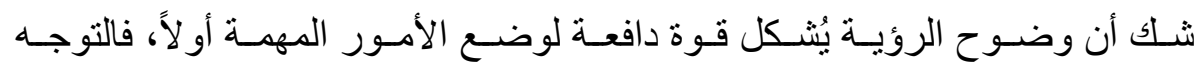
الاستر اتيجي يكون بمثابة البوصلة التي توجه جهود المؤسسة وفقاً لأولوياتها. وضوح الأدوار المطلوبة لتنفيذ التوجهـ المستقبلي: وتدور حـول مـا يُشنكل إطـار اً

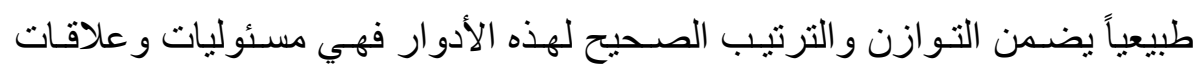

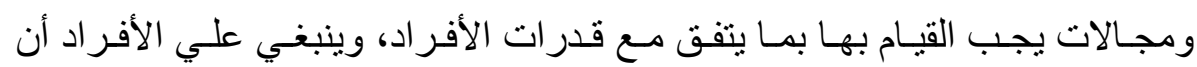

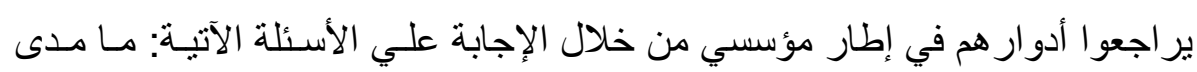

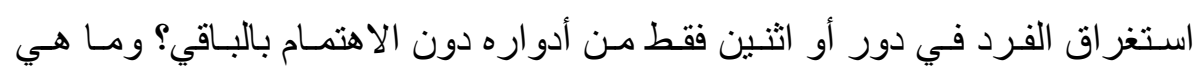

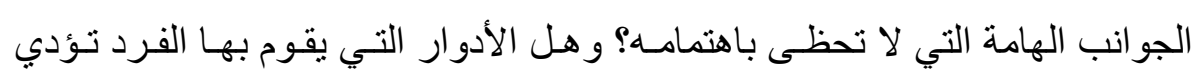

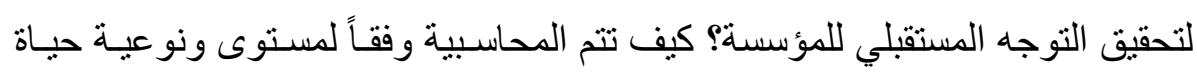

$$
\text { القرد إذا اهتم بالتو ازن بين هذه الأدوار؟ }
$$

المراجعة المستمرة للأهداف حسب الأدوار: فبعد تحديد الأدوار المطلوبـة يجب أن تحدد الأمور الهامة التي يُمكن القيـام بهـا بمـا يضـمن الحصـول علي أفضـل النتـائج بالنسبة لكل دور، ويمكن المر اجعة المستمرة للأهداف من خلال الإجابة علي الأسئلة الآتية: ما الأمر المهم في كل دور من الأدوار المطلوبة والذي يُبساعد في الحصـول علي أفضل النتائج؟ وما الخطوات التي تُحقق كل دور بفعالية؟ وماذا يحدث لو لو تمكن الأفر اد من إنجاز الأهداف؟ و هل سيتحقق الرضا الوظيفي لدى الأفراد؟ وماذا يحدث 
إدارة أولويات برنامج الدبلوم العام في التربية بجامعة الأزهر في ضوء مدخل المقارنة المرجعية benchmarking

لو تم إنجـاز بعض الأهداف فقط دون البعض الآخر ؟ وهل ستصبح فرق العهل

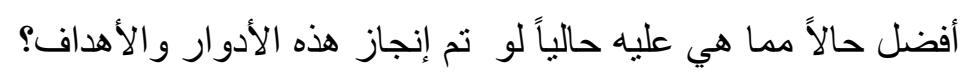

المشـاركة الفعالـة في تعديــ البـائل والخيـارات التـي مـن شـأنها تحسـين الوضـع التنافسي للمؤسسـة ومناقتـتها وفقاً للتغيرات و التطـور ات في البيئة المحيطـة، بمـا يسمح بالتجديد المتوازن مـن خـلال إتاحـة الوقت للتفكير بشكل مستمر في تحقيق

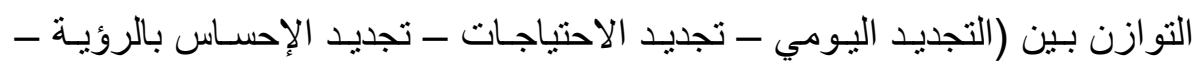

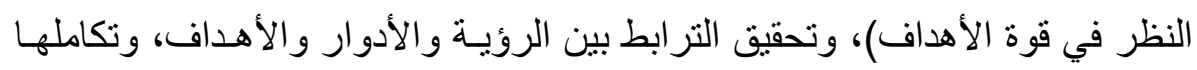
مع إجر اءات التنفيذ و المُتنابعة.

التأكيد علي توازن الأدوار: يجب أن يكون هنـاك توازنـاً بين ديناميـة تنفيذ الأدوار،

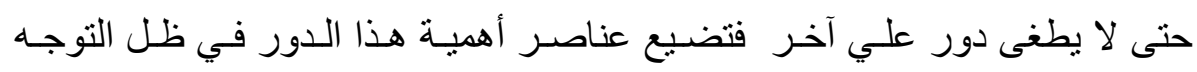
المستقبلي للمؤسسة، ففي المؤسسات الجامعية ينبغي التوازن بين (التعليم ـ البحث

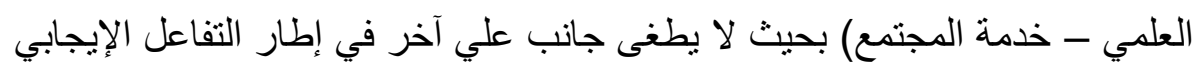

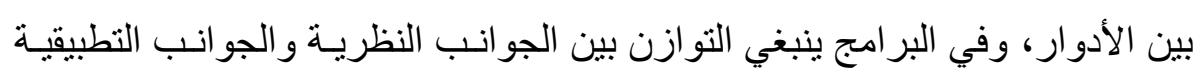

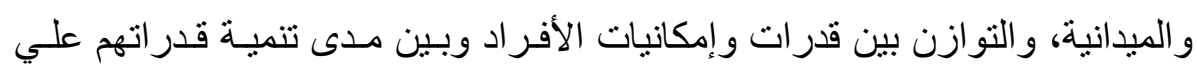
بذل مزيد من الجهـ.

تكامل إدارة الوقت مع ترتيب الأولويـات وتتفيـها: تهدف أنظمـة إدارة الوقت في

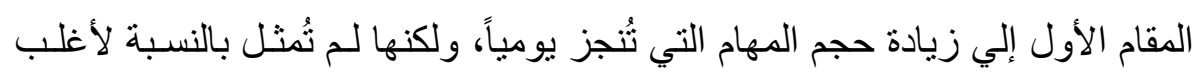

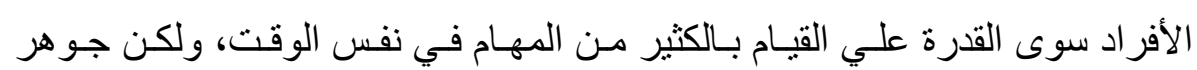

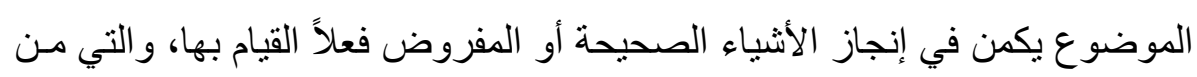
شأنها تُضيف قيمة للمؤسسة وتُشهم في الارتقاء بجودة أدائها، فنحن بحاجة إلي نظسام

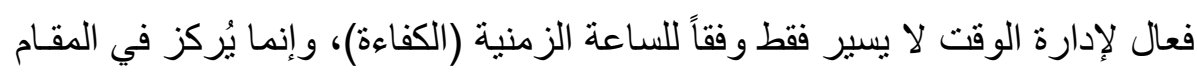

مجلة كلية التربية- جامعة عين شمس 
د/ أحمد عبد الفتاح حمدي الهنداوي

الأول علي البوصلة الداخلية المتمثلة في الفعالية، وتضييق الفجوة بين (الطريقة التي التي

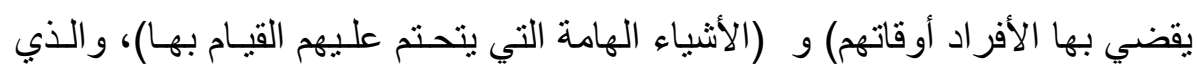
من شأنه يُضيف شكل من أنشكال التقدم و الرقي في بيئته المحيطة.

التوجيه نحو التركيز علي الأمور المُهمـة بـلا منسه علـي الأمسور المستعجلة فقط: يجب التمبيز بين ما هو (مهم ومستعجل) مثلـ: أزمـات وتعليمـات طارئـة مـن جهـة عُليا ومشروع أوشك علي الانتهاء. ومـا هو (مهم وغير مستعجل) مثنل: علاقـات وفرص جديدة و إبـاع و أنشطة تخطيطيـة. ومـا هو (غير مهم ومستعجل) مثنل: مقاطعـات ومكالمـات وبريـد وتقـارير و أنشـطة عامـة. ومـا هـو (غيـر مهـم و غيـر

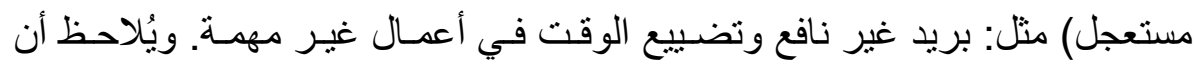
الاهتمام بما هو (مهم و غير مستعجل) يعمل علي تحسين جودة المؤسسـة بصـورة ملحوظة وتؤثر بثدة علي تتفيذ كافة الانشطة، مما يستلزم تخصيص أوقات محددة وفقاً لجدول زمني للاستثمار فيها. التقييم والمساءلة: وذللك للتأكد مـن الالتنز ام بتحقيق التوجـه المستقبلي، بحيـث يتم تجنب تكرار عمل غير موفق أو نفس الأخطاء، وتصحيح المسار، ومن أهم العواملـ التي تساعد علي نجاح إدارة المؤسسات التعليمية، وجود نظام فعال للمسـاءلة بسـاعد

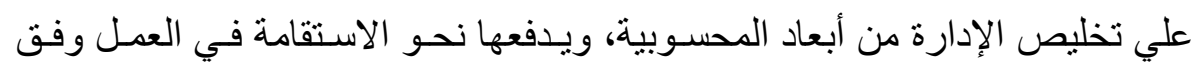
قو اعد الجدارة والاستحقاق وتكافؤ الفرص، بما يؤدي إلي ارتباط الفرد وو لائه للنظام

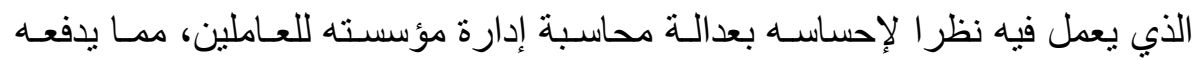
لبذل أقصى ما لديه من جهد لرفع مستوى عطائه في النظام. و هناك العديد من الأساليب التي تساعد علـي إدارة الأولويـات، ومـن أبرزهـا مـاــا

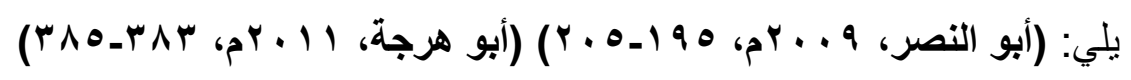


إدارة أولويات برنامج الابلوم العام في التربية بجامعة الأزهر في ضوء ملخل المقارنة المرجعية benchmarking

تحديد الأولويات وترتيبها باستخدام مجموعة من المحكات أو العوامل، مثل: (مدي مئة الحاجة إلي التطوير - مدي أهميـة وخطورة المشكلات، مـن حيث عدد المتـأثرين

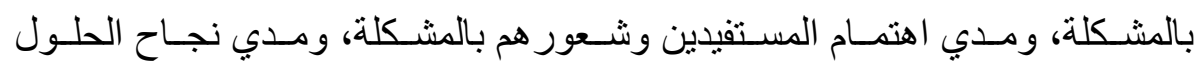

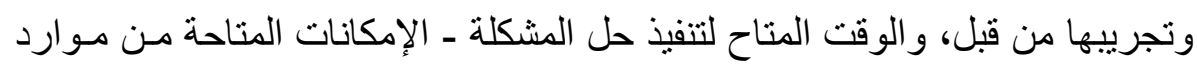

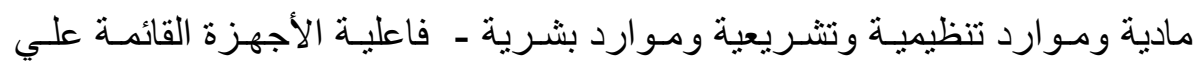

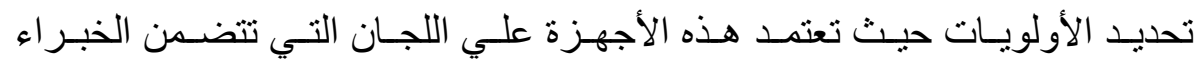
و المتخصصين والقيادات التي تستخدم أسلوب التفكير الجماعي الذي يحقق الثمول. الخبرات الموضوعية، ويتضمن مجموعة من المبادئ العامة التي تعـاون المسـؤلين و المخططين أثناء إجر اء مهام عملية إدارة الأولويسات وتتمثنل هذه المبادئ في: (أن تتم عملية تحديد الأولويات في ضوء السياسة العامة للدولة، ومر اعاة اتسـاق البر امج و المشرو عات مع أيديولوجية المجتمع وقيمه السائدة، ومحقــا لأهدافهـ الاسـتر اتيجية، وأن يكون هدف عملية تحديد الأولويات هو اتخاذ القرار ات بـالخطط والبر امج التي لئه تشبع حاجات المستفيدين وتعـالج مشكلاتهم في ضـوء الإمكانـات المتاحـة، ووجـود جهاز أو لجان متخصصة للقيام بمهام تحديد الأولويـات بحيث يتو افر لها إمكانـات ماديـة و إمكانـات بثـرية وتتظيميـة، واسـتخدام الوسـائل و الأسـاليب العلميـة الحديثـة لتحديـ الأولويـات ومنهـا الدراسـات و المسـوح وبحـوث تقدير الحاجـات ومقـاييس الاتجاهـات وبحـوث تقيبم فاعليـة الخدمات، بالإضــافة إلـي تـوافر نظم للمعلومـات و البيانات اللازمة لتقدير الأولويات.

مصفوفة الأهمية والأداء، و التي يمكن من خلالها تحديد مكانـة كل مجـال مطروح للتحسين و التطوير في المناطق المحدة في المصفوفة، والتي يمكن توضـيحها مـن

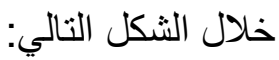

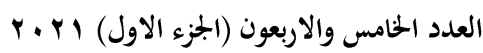

(34)
مجلة كلية التربية- جامعة عين شثس 


\section{د/ أحمد عبد الفتاح حمدي الهنداوي}

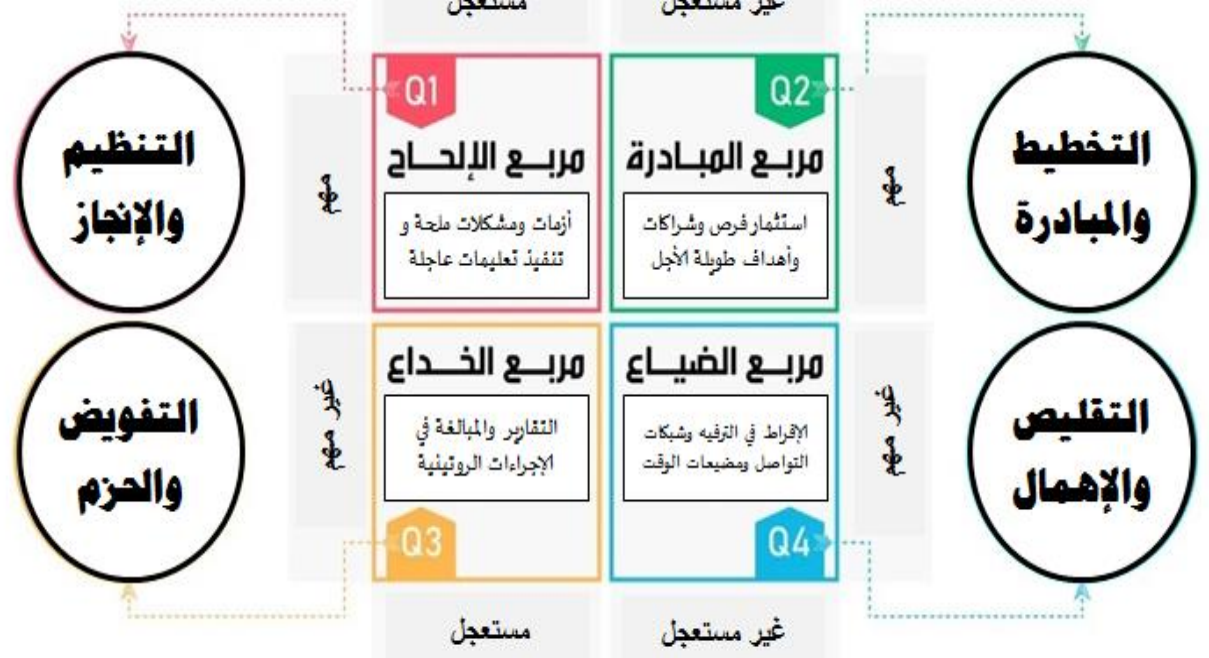

شكل (1) مصفوفة آيزنهاور The Eisenhower Matrix لإدارة

الأولويات

ومن الضروري التمييز بين المجالات التي تحتاج إلي تحسين مقارنة بالجامعات الأخرى، و المجالات التي قد تؤدي إلي الإسر اف في استخدام الموارد، وذلك فقاً لمعيـاري (درجة أهميتها بالنسبة للمستفيدين - مستوى الأداء بالنسبة للجامعـات الأخرى)، وتكمن النس الفعالية في استثمار مربـع المبـادرة بمـا يُضـيف قيمـة للمنظومسة والارتقـاء بجـودة أدائهـا وتميزها.

ومن العوامل التي تُساعد علي تحقيق فعاليـة إدارة الأولويـات: وضـوح الهيكل

الداخلي/ البناء التنظيمي لادي كافة المشاركين في إدارة المؤسسة الجامعيـة، بحيث يرسم العلاقات التكاملية بين كافة الوحدات التنظيمية، التنسيق و التعاون بين الأجهزة سو اء علي المستوي الأفقي أو الر أسي، وزيادة دينامية الأعضاء داخليـا وتكامـل أدو ارهم في إطـار 
إدارة أولويات برنامج الدبلوم العام في التربية بجامعة الأزهر في ضوء مدخل المقارنة المرجعية benchmarking

تعاوني، وتوفير العدد اللازم مـن المؤهلين لأعمـال التخطيط و التنفيذ، والتعـاون الوثيق

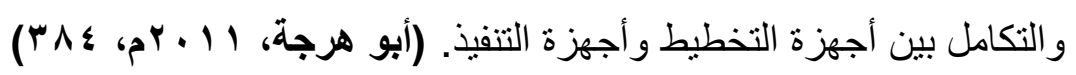

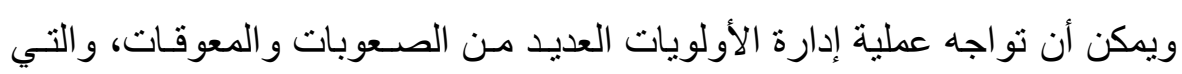

يمكن تحديدها فيما يلي: (غياب الوعي التخطبطي لدى بعض المشاركين في اتخـاذ القرارات التخطيطية وأزمة الحوار بين المخططين ومتخذي القرار ــ عدم الاعتمـاد علي الأسلوب

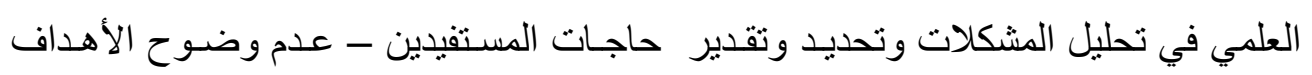
و أساليب تنفيذها إجر ائيا وفق خطة زمنية محددة - غياب السياسات الموجهة لمعـيير تحديد الأولويات وترتيبها واختبار البر امج و المشروعات - عدم الاتفاق مسبقاً علي معـايير تحديد

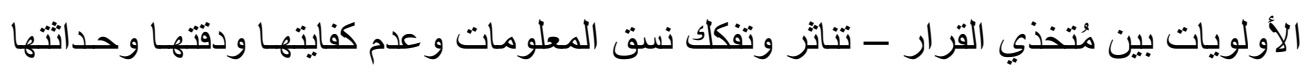
- ضعف الأجهزة التخطيطية و غياب الخبر اء والفنيين و المتخصصسين). (السروجي، طلعت

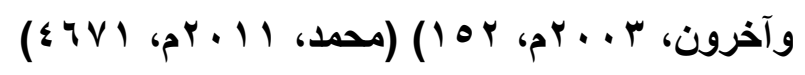

ومن خلال ما سبق يتضح أن (إدارة الأولويات) تتضمن مجموعة مـن العمليـات

و الإجر اءات التي يمكن من خلالها تحديد قضايا أو مجالات التحسين الجامعي، ودراستها وتحليلها، وترتيبها وفقاً لأهميتها بالنسبة للمستفيدين، وبالنسبة لمستوى الأداء الجامعي في

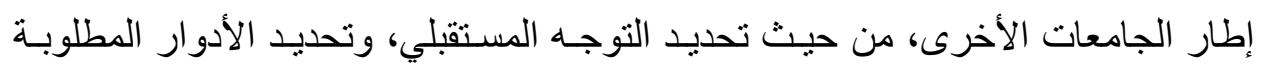
لتنفيذه، والمر اجعة المستمرة للأهداف حسب الأدوار، و المشاركة الفعالة في تحديد البدائل

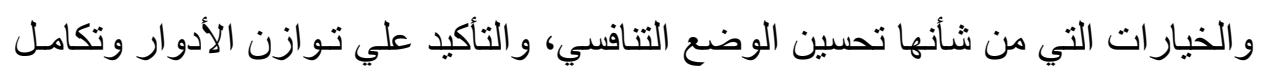
إدارة الوقت مع ترتيب الأولويات وتتفيذها، والتوجيه نحـو التركيز علـي الأمسور المُهمهـة

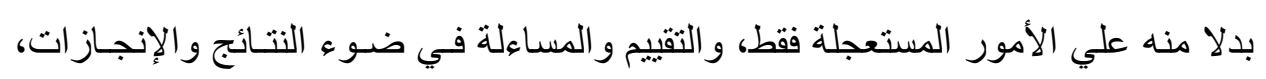

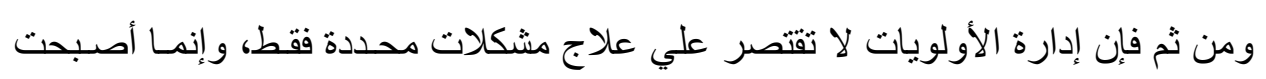
قرارات علاجية تتجه إلى تطوير الواقع نحو المستقبل.

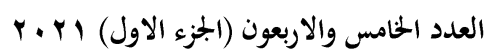

(36)
مجلة كلية التربية- جامعة عين شمس 
د/ أحمد عبد الفتاح حمدي الهنداوي

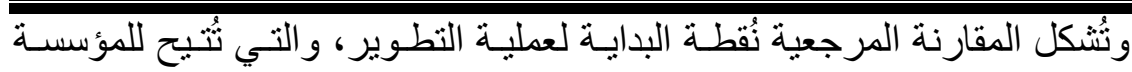

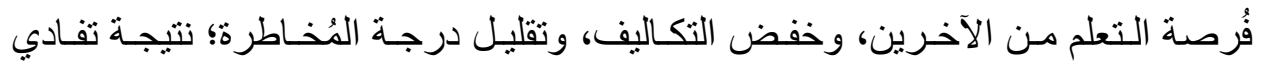

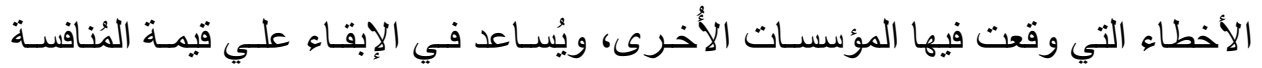
للمؤسسة و التغيرات الحاصـلة في مُحيطها، واستخدام المعلومـات المُتحصل عليهـا من عملية المُقارنة بشكل يُساعد المؤسسة في وضع خطط لتحسين الأداء، كمـا تُمكن عمليـة

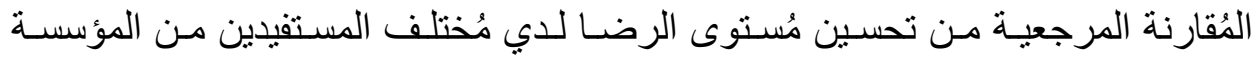

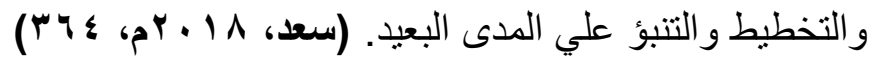

و هنـاك العديـد مـن الدر اسـات التـي تناولـت مفهـوم المقارنـة المرجعيـة كمــخل تطويري للمؤسسات الجامعية، و التي تم الرجوع إليها لمر اجعة الرؤى التنظيريـة و الفكريـة

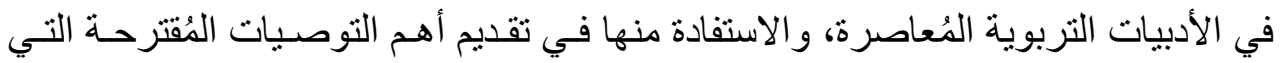
يمكن أن تُسهم في إدارة أولويات برنامج الدبلوم العام في التربية بجامعة الأزهر.

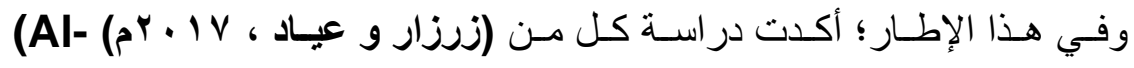

عhalifa, 2015)

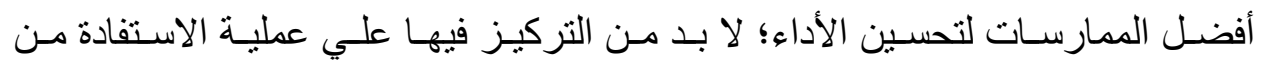
المعارف والمعلومات التي يتم الحصول عليها من المنظمات المرجعية، ووضعها موضع التنفيذ بهدف تقليص الفارق بين المنظمة والمنظمات المرجعية، حيـث إن الفتـل في ذلك يؤدي إلى هدر الوقت والأموال التي تحملتها المنظمة في الحصول على تلك المعلومـات، و أن الالتـز ام الكلي بالنز اهـة و التعامـل ينطلق مـن فهم حقيقي لمعـاني و أبعـاد وحيثيـات أسلوب المقارنة المرجعية ، بمعنى آخر تجنب الفهم الخاطئ عن المقارنة المرجعية، فهي ليست "الخداع" و لا "عدم الثرعية"، و لا "اللاأخلاقية" فهذه المفـاهيم قد تعطي تصـوراً بأن المقارنة المرجعية هي الانتفاع غير المشـروع مـن منـافس غافل، باستنسـاخ و تقليد منتجاته وخدماته بدون علمه أن هذا ليس مقارنة مرجعية. 
إدارة أولويات برنامج الابلوم العام في التربية بجامعة الأزهر في ضوء ملخل المقارنة المرجعية benchmarking

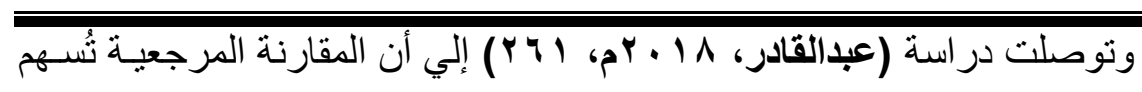

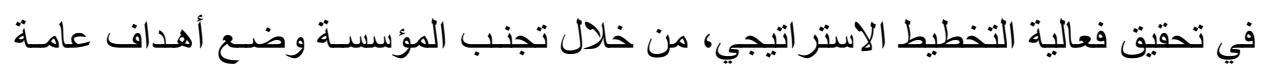
ومطاطية، ووضـع أهداف ذات مصداقية يســل تحقيقها، كمـا أنـه يثـجع ثقافة التغييـر وتطبيق فلسفة التحسين المستمر ، بالإضافة إلى أنه يعد أداة جيدة للتعلم الفعـال والدخول في مجالات الابتكار و التجديد، بالإضافة إلى أنه يزيد مستوى الكفـاءة و الفعاليـة التنظيميـة الإضية

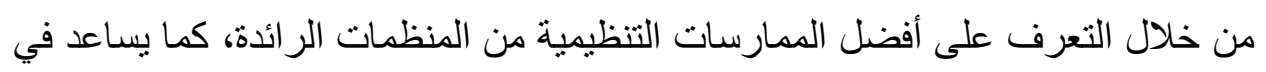

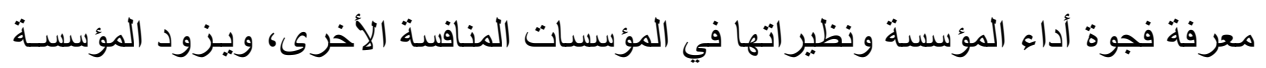
بالقدرة على الإبـداع الفردي و الجمـاعي، ومعرفـة نقـاط القوة وتعزيز هـا ومعالجـة نقـاط الضعف، بما يحسن من الوضع التنافسي للمؤسسة.

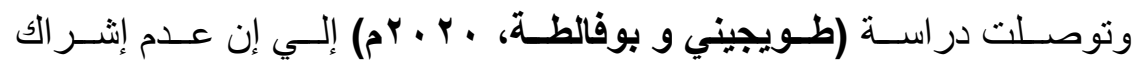

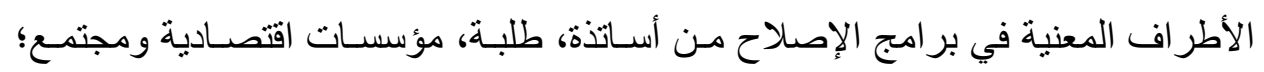

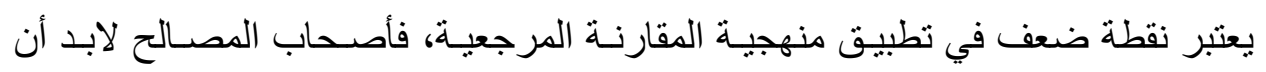

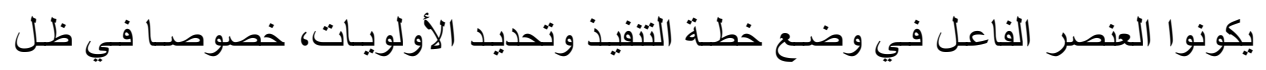
السعي نحو الانفتاح وتفعيل علاقة الجامعة مع محيطها. كما أن عدم أخذ الإدارة الجامعية ببعض المؤشرات العالمية كأساس للتقييم، ومن بينها مؤشر ات جـودة التعليم العـالي وفقا

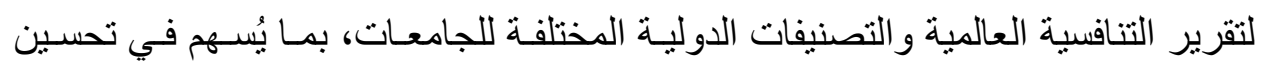
جودة المخرجات الجامعية، وتحسين مقروئية ومصداقية شهاداتها على المستوى العالمي.

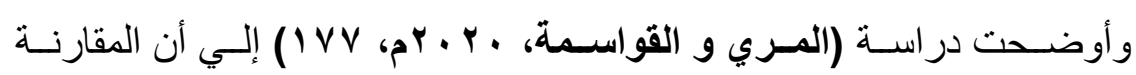

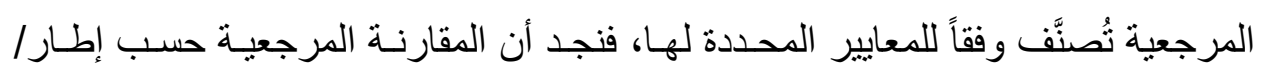
مكان المقارنة بالنسبة للمؤسسة؛ تنقسم إلـي (مقارنـة مرجعيـة داخليـة، ومقارنـة مرجعيـة

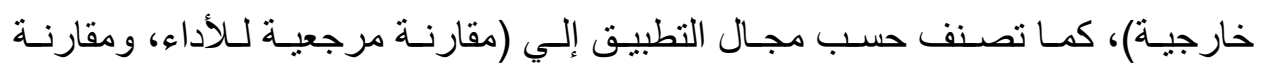
مرجعية لنتائج التطبيق)، وتُصنَّف حسب مجال المنافسة، فنجد (مقارنـة مرجعيـة تتافسية

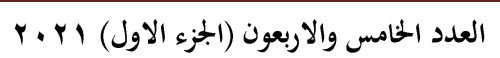

مجلة كلية التربية- جامعة عين شمس 


\section{د/ أحمد عبد الفتاح حمدي الهنداوي}

ومقارنة مرجعية غير تنافسية)، بالإضافة لتصنيفات حسب معايير أخرى، مثنل (مقارنـة

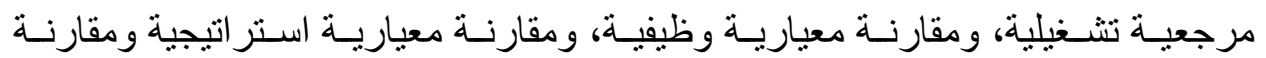
معيارية دولية).

و علي الرغم من تعدد التسميات و التصنيفات وتتو عها، إلا أن المقارنة المرجعيـة

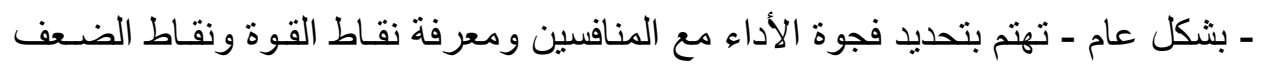

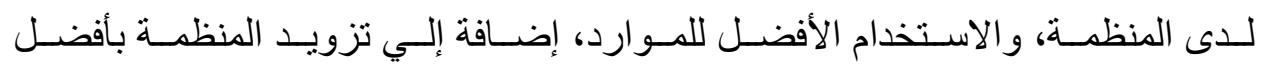

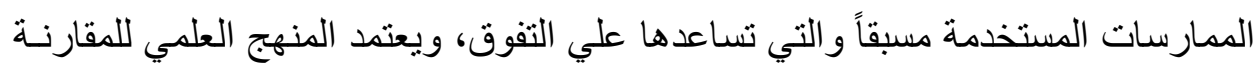

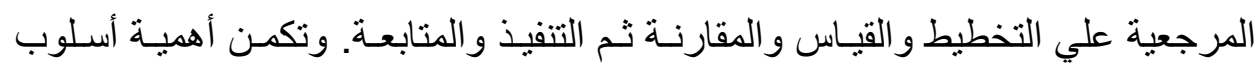

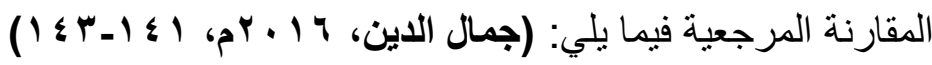
إتاحة فرص التعلم المستمر لجميع الوحدات ونقل الخبرات و المعسارف من الوحدات الأخـرى؛ بهدف تغييـر نظمّ وأسـاليب العمـل التقليديـة وإحـداث تغييـر في الثقافـة

التنظيمية.

إتاحة الفرصة لإدارة المؤسسـة للتوجـهـ نحـو النـــاذج الأفضـل لـلأداء و الجـودة التـي توفر لها فرص تحقيق رضاء متلقي الخدمات، وينعكس ذلك التوجـه علـي العـاملين في مساعدة الإدارة علي اتخـاذ القرارات وإيجـاد الحلول المناسبة للمشكلات التي يو اجهونها في العمل، ويتيح هذا المدخل التزام العاملين بتطبيق استر اتيجيات الجودة. تحسين القدرات الإبداعية والتجديدية للإدارة من خلال فريق عمل مسئول عن قيادة

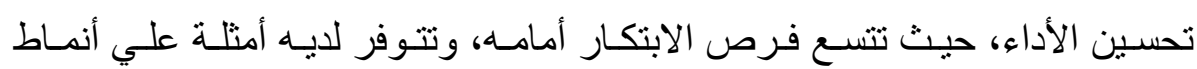

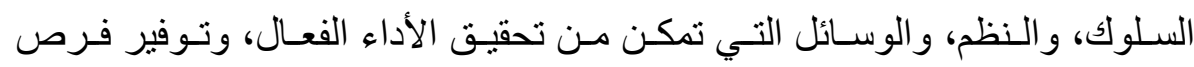

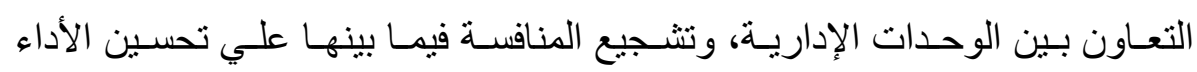
و إدخال آليات السوق ضمن استر اتيجيات العمل. 
إدارة أولويات برنامج الدبلوم العام في التربية بجامعة الأزهر في ضوء مدخل المقارنة المرجعية benchmarking

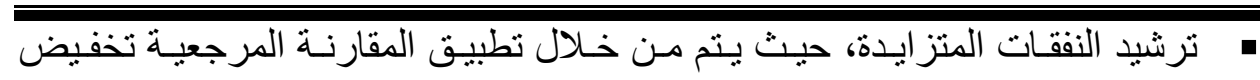
تكاليف الخدمات التي تكون مرتفعة، فتلجأ الوحدات الإدارية إلي البحث عن وحدات أخرى تقوم بتقديم نفس الخدمات بتكلفة أقل. تمكين الإدارة العليا من اكتشاف أي فجوة في الأداء، وفقاً للمستويات المر غوب فيها، ومن ثم اتخاذ الإجراءات اللازمة لمحاولة سد هذه الفجوة، وذللك بتوظيف ممارسـات التهات و أساليب جديدة.

تغيير ثقافة الإدارة؛ بحيث تصبح موجهة لحل المشاكل وتحسين الأداء، و العمل عل تحقيق أهداف الممارسة الأفضل في تقديم الخدمات .

وتختلف مراحل تطبيق المقارنة المرجعيـ Benchmarking Process

من وجهة نظر المهتمين بهذا المجـال، ولكنهـا في النهايـة تتقق على الهدف العـام مـن المقارنة المرجعية وهو التحسين والتطوير، ويمكن عرض مر احل المقارنة المرجعية من

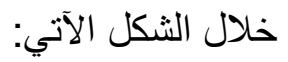

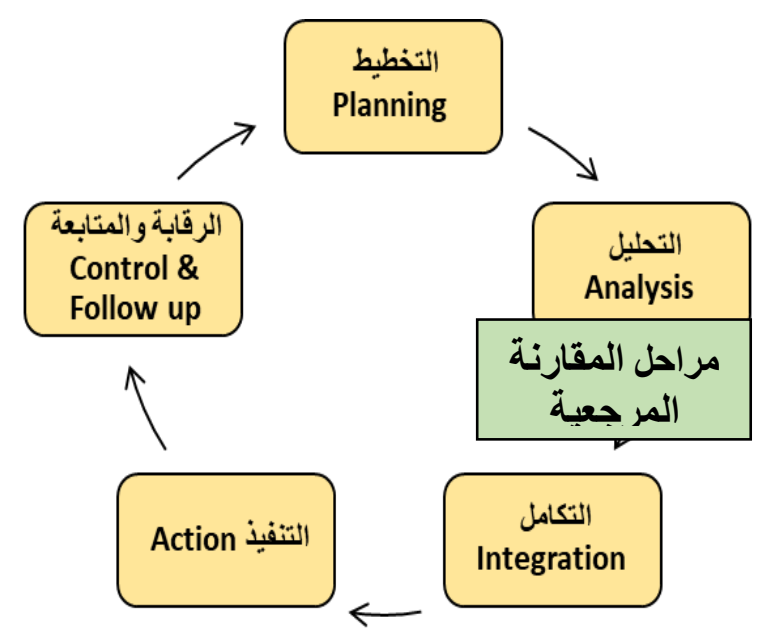

شكل (Y) مراحل المقارنة المرجعية

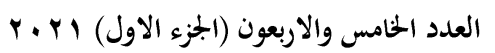

(40)

مجلة كلية التربية- جامعة عين شثس 
د/ أحمد عبد الفتاح حمدي الهنداوي

ومن خلال الثكل السابق يمكن توضيح مراحل المقارنة المرجعية علي النحو الآتي:

مرحلـة التخطيط Planning وتتضـــن هـذه المرحلـة تحديـد عمليـات المقارنــة المرجعية و فريق عمل الذي يقود تخطيطها وتنفيذها ومتابعتهـا، وتحديد المنـافس و التركيز علي المجـالات الأكثر أهميـة لمتلقي الخدمـة، وتحديد المجـالات و أفضـل الممارسات التي يتوقع لها النجاح في التطبيق، وتحديد طرق و أدوات جمع البيانات. مرحلة التحليل Analysis تتضمن هذه المرحلة تحديد فجوات الأداء بين المنظمـة و المنظمة التي ستكون مرجعاً للمقارنة، والتتبؤ بمستويات الأداء في المستقبل لكل منهما في ضوء احتياجات المستفيد من الخدمة التعليمية. مرحلـة التكامـل Integration خـلال هـذه المرحلـة يجـب على فريـق المقارنـة المرجعيـة أن يجهـز ويوصـل النتـائج لـالإدارة لكى تعهـل على تحسـين مـوارد المشرو عات وتحديد ا لأهداف لهذه المشرو عات. مرحلة التفيـ Action يتم فيها تحديد خطوات التطوير للمشـرو عات والبدء في عملية تتفيذها ومر اجعة النتائج وضبط عملية التحسين في حالة خروج الأهداف عن مسار ها المخطط. مرحلة الرقابة والمتابعة Control \& Follow up: وتتضمن منابعة التقدم في الأداء، بهدف المساعدة علي معالجة الفجوة السلبية في الأداء، وتصـيح الانحر افـات

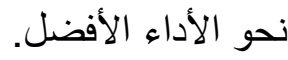

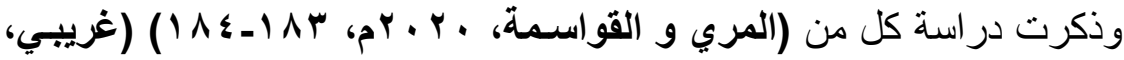

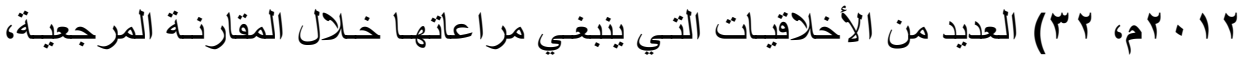

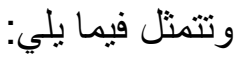


إدارة أولويات برنامج الابلوم العام في التربية بجامعة الأزهر في ضوء ملخل المقارنة المرجعية benchmarking

الأمانة والمصداقية: خاصة في تبادل البيانات أو المعلومـات المطلوبـة و المنصـوص عليها في العقد، ويُفضـل أن تكون البيانـات المطلوبـة مـن نفس النـوع ومـن جانب الطرفين، وأن لا يتم استخدام نتائج المقارنة المرجعية لأغر اض التشويه أو التسويق، و إنما يجب الحفاظ علي سرية المعلومات بوصفها خصوصيات للمؤسسة. الالتزام والمسئولية: في الغالب ما تقم المقارنة المرجعية عل عقد تتحدد فيـه حقوق وو اجبات كل طرف من الأطر اف، وعليه يصبح كل طرف ملتزمـاً ومسؤو لاً عن تتفيذ بنود هذا العقد، هذا بالإضـافة إلى عدم التوسـع في استـخدام نتـائج المقارنـات لصالح مؤسسات أخرى الا إذا كان هنالك ما ينص أو يسمح بذلك.

مبـأ شـرعية المعـايرة، مسن حيـث وجوب الانضـباط في عمليـة المقارنـة المرجعيـة و الابتعاد عن أي عمل قد يعد مـن قبيل سـرقة إنجـاز ات و إبـداعات الآخـرين، و هنـالك قاعدة ذهبية في المقارنة المرجعية تقول":لا تطلب من شريكك في المقارنة أن يخبرك

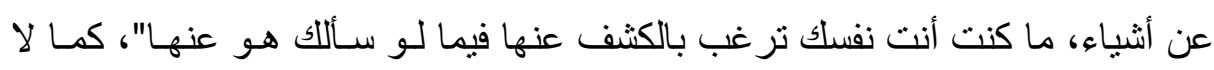
تحاول الضرر بالآخرين عن طريق المعلومات التي حصلت عليها من المؤسسة. مبأ الثقةـة، من حيث وجوب تحقيق الثقة المتبادلـة بين الثـركاء، وجمـع المعلومـات بالطرق المناسبة، و عدم نقل أي معلومة حصلت عليها من المؤسسة إلى طرف ثالث إلا بمو افقة الثريك.

مبدأ التبادل، فمـن الممكن إعطـاء الثـريك الآخر نفس القدر مـن المعلومـات التي حصلت عليها منه، ويفضل أن تبادر بهذا العـرض عنــ أول لقـاء، وتحقيق الثـر اكة بين المنافسين وتبادل المعلومات و عدم حجبها عن الثريك. مبدأ السرية، من حيث وجوب احتر ام سرية المعلومات وعدم محاولة التعرف على

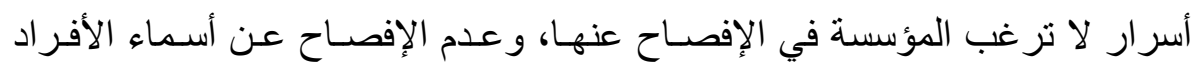


د/ أحمد عبد الفتاح حمدي الهنداوي

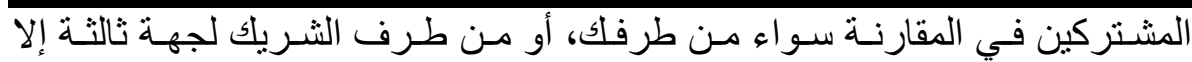

بمو افقة الجميع.

مبدأ تخصيص الاستعمال، من حيث استخدام المعلومـات فقط للهدف المحدد لها، ومعالجة المعلومات التي تم الحصول عليها من الآخرين كما ير غبون، و التعساون مـع

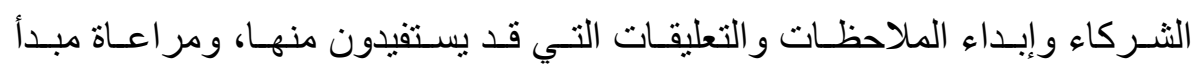
الاتصال، من خلال القنوات الرسمية.

وقد صنف (Garvin, 1993, 78-92) أهم الأنشطة الرئيسية التي

تشكل مصادر للتعلم من الممارسات المتميزة إلى خمسة أنشطة رئيسية وهي:

1 - حل المشاكل بطريقة منتظمة (Systematic Problem Solving):

وذلك من خلال الاعتماد على الطرق و الوسائل العلمية لحل المشاكل بدلاً

من التوقعات، وهو ما يدعى "الإدارة المبنية على الحقائق" وهي التي يسميها ديمنج (plan, do, check, and act cycle)

الإحصائية لتحسين عمليات صنع القرار وحل المشاكل، ومن أبرز تلك الوسائل:

قائمة الفحص (التي تستخدم لحل المشاكل و اكتشاف أسباب حدوثها)، و المدرجات

التكر ارية (و التي تستخدم لعرض البيانات وتوزيعها بغرض فحصها ومر اقبتها)، نموذج باريتو (لتصنيف المشاكل ومعرفة الأسباب التي تساهم في حدوثها)، ونموذج لنهري السبب والأثر (و التي تستخدم لمعرفة أسباب حدوث المشاكل وجذور ها) و غير ها من الوسائل، و التي تهدف ضمن إطارِ علمي إلى جمع البيانات عن مشكلة معينة و النظر في أسبابها، ويعتبر التفكير النظمي واحداً من أبرز الأساليب لحل المشاكل في إسي المنظمات المستعدة للتعلم.

مجلة كلية التربية- جامعة عين شثس 
إدارة أولويات برنامج الدبلوم العام في التربية بجامعة الأزهر في ضوء مدخل المقارنة المرجعية benchmarking

\section{r (Experimentation) - الاختبار والتجريب}

ويدل هذا المفهوم على آلية البحث عن المعرفة الجديدة واختبار ها. كل

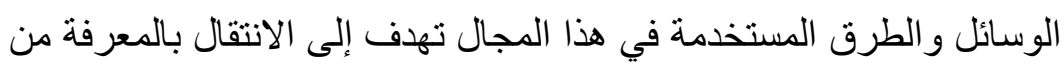

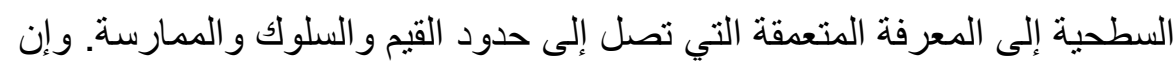
الخبر اء في كافة المجالات يعددون إلى تطوير استر اتيجيات لتجريب الأشياء، حتى إلى

لا يو اجهوا المصاعب إذا كانت النتائج المتوقعة مأساوية، وهذا ما يشابه عمل المهندسين في بناء نماذج أولية للمشاريع، أو ما يقوم به مهندسو الملاحة الجوية عند اختبار هم نماذج الطائر ات الجديدة، و الذي يتيح لهم استكثاف النتائج بغرض فهم العمليات المختلفة، وتعتبر هذه الوسائل عاملاً مساعداً لربط الفريق بعضه ببعض هض لهن وبفهم مشترك وهي تجيب عن السؤال "ماذا سيحدث بعد؟ ". ولنجاح هذه العملية

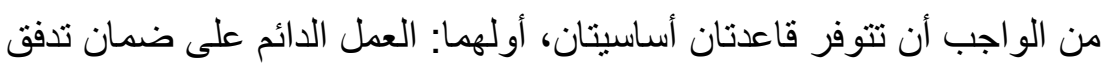
أفكار إبداعية بشكل مستمر، ولو من خارج المنظمة، من خلال دعم الثقافة والبيئة التنظيمية، ومن خلال توظيف قادة و أفر اد مدربين على عمليات تصميم التجارب و القيام بها ومن ثم تقييمها بشكل صحيح، ويؤكد Garvin على ضرورة أن تشتمل ومن ونس البر امج التدريبية على ما يزود الأفر اد بمثل هذه المهار ات. وثانيهما: نظام حفز مناسب يشعر الأفراد أن فوائد هذه التجارب تبرر تكاليفها.

\section{r - التعلم من الخبرات الماضية (Learning From Past Experience):}

على المنظمة أن تعيد النظر بشكل دائم في نتائج تصرفاتها الماضية، لمر اجعتها وتقييم نقاط القوة والضعف فيها بشكل منتظم، وتوصيل تلك المعلومات إلى الأفراد ليقوموا بعمليات التقويم والتصحيح والتعلم. وتعتبر سلسلة اتخاذ القرارات ومواجهة المشاكل مصدراً مهماً لتعلم الأفراد حيث تمكنهم من التنبؤ 
د/ أحمد عبد الفتاح حمدي الهنداوي

بردود الأفعال المستقبلية وأخذها بعـين الاعتبار في المحاو لات القادمة. حيث يُقال إن هؤلاء الذين لا بسنطيعون تذكر ماضبهم، هم في الحقيقة يعيدونه.

Learning From The Experiences of ) - التعلم من خبرات الآخرين

:(Others

المصدر الآخر من عملية التعلم يأتي من خارج المنظمة سواءً من

المنظمات المنافسة أو من الموردين أو المستهلكين وغيرهم، وحين تتبع المنظمة أسلوباً في دراسة توقعات المستهكين عن الخدمة التي تقدها، أو التعرف على النقاط التي يعتمدها المستهلكون كأساس لتقييم أداء المنظمة، فهذا يمنحها فرصة للتعلم.

\section{• ـ نقل المعرفة (Transferring Knowledge):}

يعتمد نجاح التعلم في المنظمة واكتساب المعرفة على إمكانية توصيلها إلى أفر اد المنظمة في الوقت المناسب، ويمكن توصيلها مباشرة عن طريق حلقات التدريب و التعلم والنقاش، أو بواسطة شبكات المعلومات المختلفة. ولتحقيق هذه الغاية بسرعة Just-in-time Learning ( مناسبة فقد تم إطلاق مصطلح نظام التعلم الآني (System الذي يعمل على تزويد المنظهـة بالمعرفة عبر قنوات تكنولوجية مختلفة، وضمن شروط معينة تتلاءم مع طبيعة المنظمات، وهي بحاجة إلى درجة عالية من الجودة والدقة والسر عة التي تتأتى من خلال التخطيط السليم لها.

وبالرغم من أن المنظمات في مختلف مراحل تقدمها تقوم بالعديد من الممارسات و الأنشطة الهادفة إلى منح فرص التعلم لأفر ادها، و إن كانت بنسب قليلة، Ellinger; et. ) إلا أنها تفققد إلى الوجهة الصحيحة والتكامل المنطقي، وقد أشنار سبعة أنشطة رئيسية تُعد مصدراً لتعلم المنظمة والأفراد، (All, 2000, 1-9 و هي: (إناحة فرص التعلم المستمر للأفراد - حفز ثقافة التساؤل والحوار في 
إدارة أولويات برنامج الدبلوم العام في التربية بجامعة الأزهر في ضوء مدخل المقارنة المرجعية benchmarking

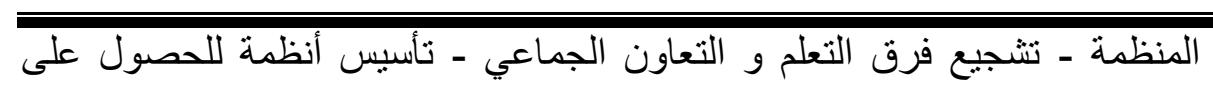

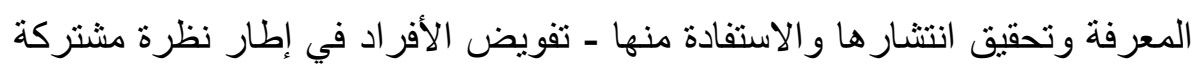
ـ دعم علاقات المنظمة بالبيئة المحيطة ـ دعم نشاطات القادة في تحفيز عملية التعلم على مختلف المستويات الفردية و الجماعية و التنظيمية). وفي دراسة ميدانية أعدها مجموعة من الباحثين في مركز دراسات التعلم التنظيمي وطبقت على أربع شركات عالمية، توصلت إلى أن هنالك عشرة أنشطة رئيسية تعتبر مصادر مهمة للتعلم من الممارسات المتميزة وهي على النحو التالي:

(Nevis; et. All, 1995, 73-85)

- إجر اء در اسات عن البيئة الخارجية وجمع المعلومـات بثكل مستمر، مثنل إجراء

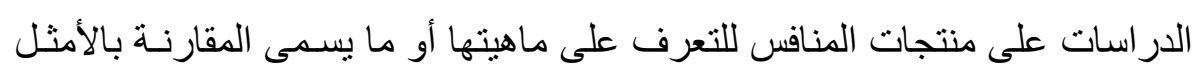

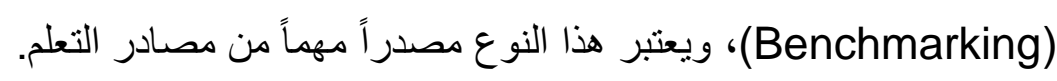
- - إدر الك الفجوة بين الأداء المتوقع من الأفراد و الأداء الفعلي بشكل جماعي. - الاهتمام بقياس وتقييم أنشطة المنظمة الخاصة بالتعلم بشكل مستمر . - - تشـجيع الأفر اد على تجربـة أثنـياء جديدة، ودعم ثقافـة التســاؤل، وتأسبس هيكل

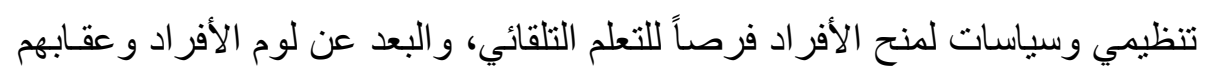
في حالة الخطأ.

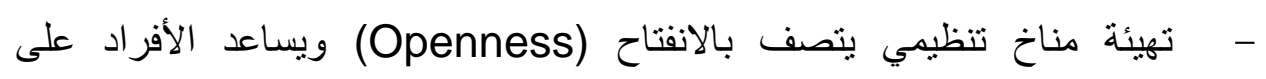

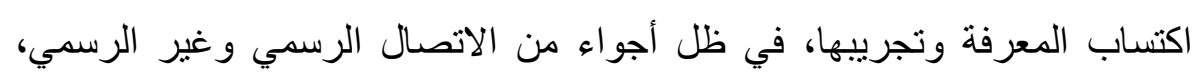
تدعو إلى المشاركة في حل المشكلات وصنع القرار ات ومناقشتها بشكل جماعي. - دعم عملية التعلم المستمر في كل المستويات، وسعي المنظمة إلى التدرج في تطوير مهار ات الأفر اد وقدر اتهم.

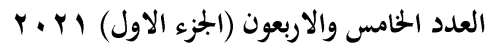

مجلة كلية التربية- جامعة عين شمس 
- - المرونة في تطبيق الطرق و الوسائل و الإجر اءات التنظيمية، وتقبل التغيير. - - تقبل إبداعات الأفر اد بطريقة سليمة، وتتجيع الأفكار الجديدة والطرق المستحدثة. - التركيز على ضرورة تطوير أنماط قيادية تتصف بالتفاعل والمشاركة الإيجابية، لما لها من دور أولي في دعم عملية التعلم. - - تطوير أنماط تفكيرية حديثة لرؤية العلاقات التي تربط الأنظمة ببعضها، و التي تشكل الروابط بين الوحدات التنظيمية وأهدافها المشتركة، بهدف إدراك دينامية الأنظمة، بحيث تسهل عملية اكتشاف الأخطاء وحل المشاكل. ومن خلال ما سبق يتضح أن المقارنة المرجعية منهجية علمية؛ يمكن من خلالها تحديد الفجوات بين الأداء والأداء الأفضل والتعرف علي أسبابها سعياً لمعالجتها، كما تتميز بتعدد أنواعها والتي تساعد في التعرف علي الخبرات و التجارب الناجحة المبتكرة داخل الجامعة وخارجها، وتعمل علي انخفاض الذاتية في تحديد أولويات التحسين وترتيبها والحصول علي البيانات اللازمة لصنع قرارات أكثر فعالية، وتمر بخطوات منطقية متمثلة في الإعداد والتخطبط ثم جمع البيانات

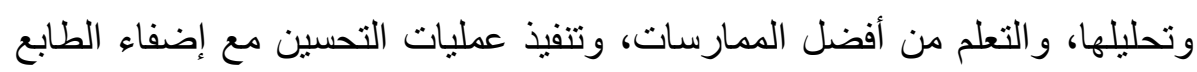
المؤسسي، ومتابعتها من أن أجل توجيه وتصحيح الانحر افات.

ثانياً: مقومات إدارة أولويات برنامج الدبلوم العام بجامعة الأزهر يسعى برنامج الدبلوم العام في التربية لإعداد المعلمين وفق النظريات التربوية و النفسية، وتزويدهم بالخبرات العلمية والمهنية والثقافية، وتزويدهم بالكفايات (المعرفية ـ المهارية - الوجدانية) التي تمكنهم من النمو في المهنة وزيادة إنتاجيتهم التعليمية، حيث تؤكد فلسفة إعداد المعلم على أن المعلم الجيد هو العنصر الأساس لتعليم يحقق أهداف المجتمع وتطويره، كما أن تحسين إعداد المعلم ورفع مستواه يشكل الخطوة الأساسية في إصلاح النظام التعليمي، واختيار أفضل العناصر ملاءمة لمهنة التدريس 
إدارة أولويات برنامج الابلوم العام في التربية بجامعة الأزهر في ضوء ملخل المقارنة المرجعية benchmarking

من خلال معايير وضوابط تضمن انضمام العناصر الملائمة نفسيا ومهنيا و علميا لمهنة التدريس. وفي هذا الإطار؛ يمكن عرض أهم المقومات الأساسية والتي تشكل منطلقاً

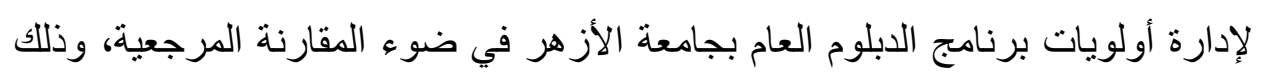

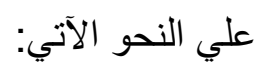

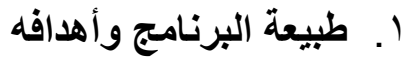

يعد برنامج الدبلوم العام في التربية أحد البرامج الدراسية التي تمنحها كلية

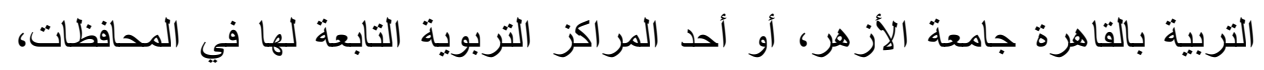
بهذف الإعداد المهني (التربوي والنفسي) للارسين، و إكسابهم المهارات و الخبرات

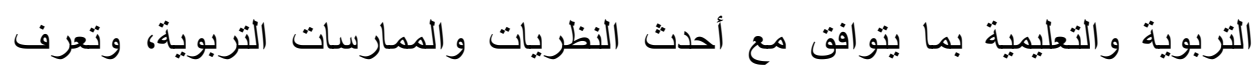
الدارسين على الجديد في طرق التدريس ووسائل التعليم والنظريات التربوية والنفسية،

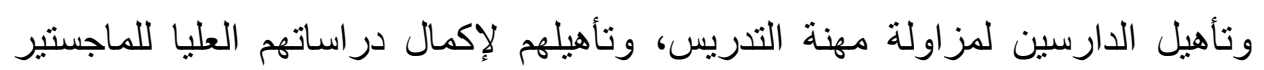
و الدكتور اه في مجال التربية و علم النفس. (كلية التربية - جامعة الأزهر، V V. . Yم)

r. ب خصوصية كلية التربية بجامعة الأزهر

ترجع فلسفة إنشاء كلية التربية جامعة الأزهر الي إعداد المعلم المسلم الذى

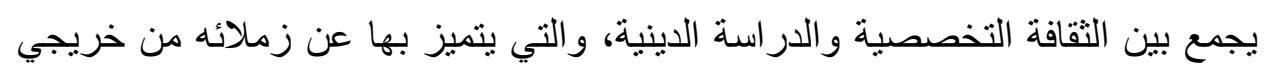
كلية التربية بالجامعات الأخرى، وأن تجعل العلوم التربوية، وأساليب التربية الحديثة في خدمة الإسلام والأمة الإسلامية والعربية وربط الدين بالحياة وإجراء البحوث

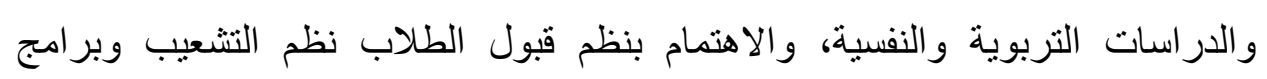

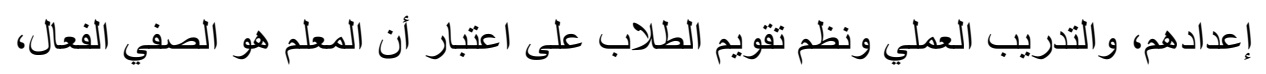

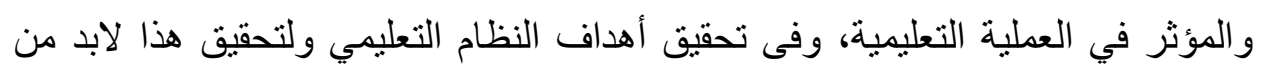
توفير المعلم الكفء الذى يتم إعداده إعدادا مناسبا فيما يتفق من التطورات المستحدثة

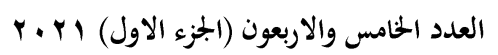

(48)
مجلة كلية التربية- جامعة عين شمس 
د/ أحمد عبد الفتاح حمدي الهنداوي

بحيث يكون قادر ا على مواجهة هذه التحديات وتسعى أيضا كلية التربية لتحقيق أهدافها.

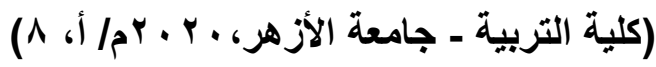

r. تعدد وتنوع مقررات البرنامج وشمولها

تؤهل مقررات برنامج الدبلوم العام في التربية بجامعة الأزهر الطلاب لمهنة التدريس ومدتها سنة واحدة للمتفرغين (در اسة صباحية) وسنتان لغير المتقرغين (در اسة مسائية)، كما أنها تسمح للحاصلين عليها بالالتحاق بالدبلوم الخاص (الأكاديمية)، بشرط استيفاء شروط القيد بمرحلة الدبلوم الخاص (الأكاديمية) في التربية و علم النفس، ويلاحظ أنه لا يشترط اي تقدير للطالب المتقدم للالتحاق بالدبلوم العام باعتبار أن هذا الدبلوم تأهيل تربوي، تؤهل الدارس لمهنة التدريس. وذللك تحت إثر اف الأقسام العلمية التي تقوم بتدريس تللك المقرات ، و هي أقسام ( أصول التربية والإدارة و التخطيط و الدراسات المقارنة والتربية الإسلامية والمناهج وطرق التدريس و علم النفس التعليمي والصحة النفسية) فضلاً عن مقرر التربية الصحية والذي يقوم بتدريسه الأقسام المتخصصة بالجامعة، ويتضح ذلك من خلال استعراض المادتين (9) ، (· (1) من القرار (1) (1) لعام ـ ـ ب م، و اللتين أوضحتا خطة الدر اسة كما يلي: جدول (1) الخطة الاراسية لبرنامج التأهيل التربوي

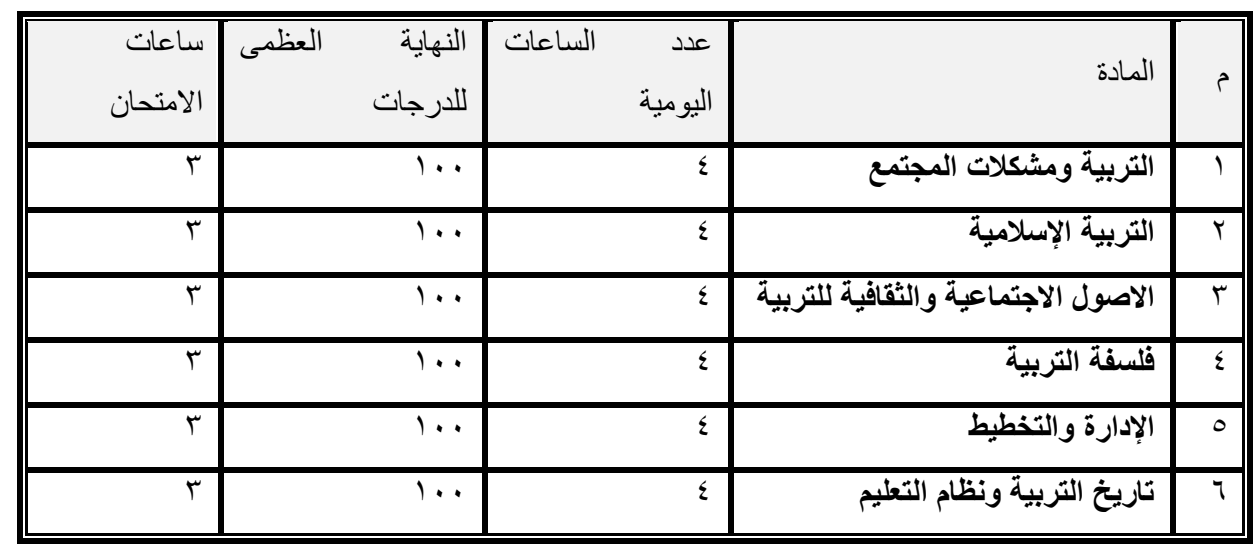

العدد الخامس والاربعون (الجزء الاول) بr.r.

(49)

مجلة كلية التربية- جامعة عين شثس 
إدارة أولويات برنامج الابلوم العام في التربية بجامعة الأزهر في ضوء مدخل المقارنة المرجعية benchmarking

\begin{tabular}{|c|c|c|c|c|}
\hline ساعات & اللارجات & اليومية & 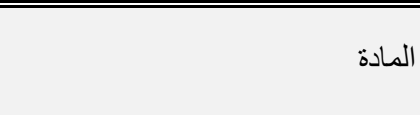 & s \\
\hline$r$ & $1 \cdots$ & $\varepsilon$ & التربية المقارنة & V \\
\hline r & $1 \cdots$ & $\varepsilon$ & المناهج & $\wedge$ \\
\hline r & $1 \ldots$ & r ب ن r r r r & الوسائل التعليمية & 9 \\
\hline$r$ & $1 \cdots$ & $\wedge$ & طرق التدريس & 1. \\
\hline$r$ & $1 \ldots$ & $\varepsilon$ & علم نفس النمو & 11 \\
\hline$r$ & $1 \ldots$ & $\varepsilon$ & علم النفس التعليمي & IT \\
\hline r & $1 \ldots$ & $\varepsilon$ & الاجتماعي $\quad$ النفسية وعلم النفس & r \\
\hline$r$ & $1 \ldots$ & $\varepsilon$ & الفكر التربوي الإسلامي & $1 \varepsilon$ \\
\hline$r$ & 0. & r & التربية الصحية & 10 \\
\hline r & $1 \ldots$ & ت & تلدريس مصغر & 17 \\
\hline - & $1 \cdots$ & - & التربية العملية & IV \\
\hline
\end{tabular}

ومن خلال استعراض الجدول السابق يُمكن التأكيد على أن المواد التربوية و النفسية التي يدرسها المتعلم في برنامج التأهيل التربوي هي جملة ما يدرسه الطالب في التي كلية التربية من علوم تربوية ونفسية وفق نمط الإعداد التكاملي، كما تتنوع المقررات التربوية والنفسية التي يدرسها المتعلم في برنامج التأهيل التربوي فمنها ما يغلب عليه الجانب الفلسفي والنظري ، ومنها ما يغلب عليه الجانب التطبيقي الميداني ، ومنها ما يتعلق بإدارة الصف و المؤسسة التعليمية، ومنها ما يهتم بخصائص نمو التلاميذ في المر احل العمرية المتتوعة، ومنها ما يتعلق بصحته النفسية وتفاعلاته الاجتماعية، ومنها ما يتعلق ببعض جوانب التربية الصحية مما يُدلل على شمولية البرنامج وتنوع مضامينه

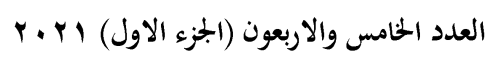

مجلة كلية التربية- جامعة عين شثس 
د/ أحمد عبد الفتاح حمدي الهنداوي

التربوية والنفسية وتكاملها، وفي هذا الإطار ينبغي أن تتكامل المعارف النظرية وتطبيقاتها التربوية لتحقق للدارس وحدة المعرفة وجودة الأداء و الممارسات.

وتسير الدر اسة وفقاً لنظام العام الدراسي الكامل، وتعقد الامتحانات مرة واحدة

في كل عام، وهذا النظام أن كان سهلاً في تطبيقه الا أنه لا يتسم بالمرونة، وغالباً ما يسبب الملل لدي الاستاذ والطالب لطول فترة الدراسة، كما أنه يلقي عبئًا أكبر على الطالب - خاصة على مستوي الدبلوم العام في التربية نظام العام الواحد أو العامين- إذ يلزمه أداء الامتحان في مقررات كاملة مرة واحدة وفي وقت محدد. وبالتالي قد يمكن أن نجعل من نظام الدراسة والامتحان خاصة على مستوي - الدبلوم العام في التربية نظام العام الواحد أو العامين - يسير على نظام الفصلين الدراسيين.

\section{ع. تعدد مراكز التأهيل التربوي وانتشارها في كافة أنحاء الجمهورية}

يوضح الجدول التالي توزيع مر اكز التأهيل التربوي، و أماكن انعقاد البرنامج بها

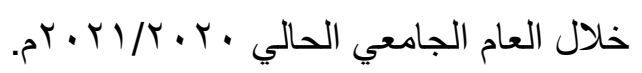

جدول (Y) مراكز التأهيل التربوي وأماكن انعقاد البرنامج بها خلال العام الجامعي

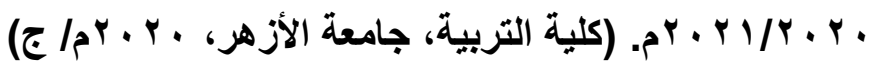

\begin{tabular}{|c|c|c|}
\hline مكان انعقاد البرنـامج & 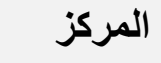 & s \\
\hline كلية التربية بنين بالقاهرة - جامعة الأز هر & القاهرة & 1 \\
\hline كلية العلوم بنين بالقاهرة - جامعة الأز هر & الجيزة & r \\
\hline كلية أصول الدين و الدعوة بطنطا - جامعة الأزهر & طنطا & ب \\
\hline كلية اللغة العربية بنين بالمنصورة - جامعة الأز هر & المنصورة & $\varepsilon$ \\
\hline كلية أصول الدين و الدعوة بالزقازيق - جامعة الأز هر & الزققازيث & 0 \\
\hline
\end{tabular}

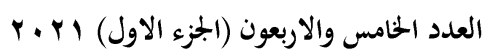

(51)

مجلة كلية التربية- جامعة عين شثس 
إدارة أولويات برنامج الدبلوم العام في التربية بجامعة الأزهر في ضوء مدخل المقارنة المرجعية "benchmarking

\begin{tabular}{|c|c|c|}
\hline مكان انعقاد البرنامج & المركز & s \\
\hline المنطقة الأز هرية بالإسماعيلية & الإسماعيلية & 7 \\
\hline كلية الدراسات الإسلامية والعربية بنات بالإسكندرية - & الإسكندرية & $\checkmark$ \\
\hline كلية الاراسات الإسلامية و العربية بنات ببني سويف - & بني سويف & $\wedge$ \\
\hline كلية الدر اسات الإسلامية و العربية بنات بسوهاج - جامعة & 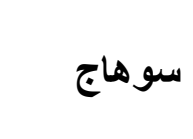 & 9 \\
\hline كلية البنات الإسلامية بطيبة - جامعة الأز هر & الأقصر & 1. \\
\hline كلية الهندسة بقنا - جامعة الأزهر & قنا & 11 \\
\hline كلية الدر اسات الإسلامية بنين بأسوان - جامعة الأزهر & أسوان & it \\
\hline
\end{tabular}

من خلال الجدول السابق يتضح تعدد مراكز التأهيل التربوي، وتغطي معظم المناطق في جمهورية مصر العربية، حيث تخدم قطاع كبير من المستفيدين في (الوجه البحري ـ العاصمة ـ الوجه القبلي ـ المناطق الساحلية).

•. ـيادة أعداد المستفيدين من البرنامج

يؤهل برنامج الدبلوم العام في التربية بجامعة الأزهر العديد من المستفيدين

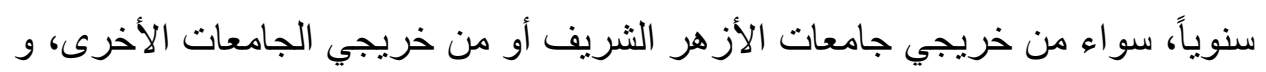
يوضح الجدول التالي أعداد الطلاب المقيدين بمر اكز التأهيل التربوي في الفترة من العام

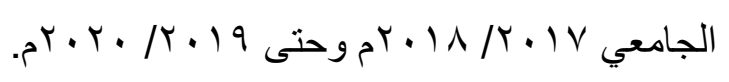

العدد الخامس والاربعون (الجزء الاول) Y r. r

مجلة كلية التربية- جامعة عين ثمس 
د/ أحمد عبد الفتاح حمدي الهنداوي

جدول (ب) إحصائية بعدد الدراسين المقيدين بمراكز التأهيل التربوي في الفترة من العام الجامعي

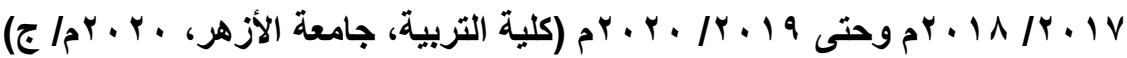

\begin{tabular}{|c|c|c|c|c|}
\hline$r^{r} \cdot r \cdot / r \cdot 19$ & م.19/r.11 & $\mathrm{r}^{\mathrm{r}} \cdot 1 \wedge / \mathrm{r} \cdot 1 \mathrm{~V}$ & المركز & 5 \\
\hline ror & KYT & tro & القاهرة & 1 \\
\hline sor & r^. & - & الجيزة & r \\
\hline vol & ONY & $\leqslant 00$ & طنطا & r \\
\hline $10 \ldots$ & 941 & $V 70$ & المنصورة & $\varepsilon$ \\
\hline $10 \leqslant \leqslant$ & I TVo & $94 \mathrm{~N}$ & الزقازيق & 0 \\
\hline rVT & rqA & $\varepsilon \leqslant Y$ & الإسماعيلية & 7 \\
\hline 1111 & $0 \leqslant V$ & rqs & الإسكندرية & $\checkmark$ \\
\hline ᄉ . & VTr & . & بني سويف & $\wedge$ \\
\hline $70 \mathrm{~V}$ & $\leqslant 9$. & TVT & سوهاج & 9 \\
\hline 7.7 & $\varepsilon r q$ & $\varepsilon Y_{0}$ & قنا & 1 . \\
\hline 1174 & $v \leqslant q$ & $91 \mathrm{~V}$ & الأقصر & 11 \\
\hline$r \cdot r$ & سו" & דמץ & أسوان & IT \\
\hline $1 \ldots 19$ & $79 \leqslant r$ & $\varepsilon q \wedge$. & لـ لى & الإج \\
\hline
\end{tabular}

ومن خلال الجدول السابق بتضح أن برنامج الابلوم العام في التربية بجامعة الأزهر

يقدم خدمة جامعية مجتمعية لقطاع كبير من خريجي جامعة الأزهر ومختلف الجامعات الأخرى المصرية وغير المصرية، حيث بلغ عدد الطلاب المتقدمين للبرنامج في الفترة من

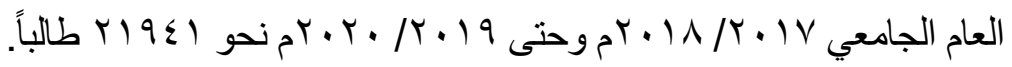

ج. دعم الموارد المالية والمادية بكلية التربية بنين بالقاهرة بجامعة الأزهر

تضمنت الخطة الاستراتيجية لكلية التربية بنين بالقاهرة - جامعة الأزهر

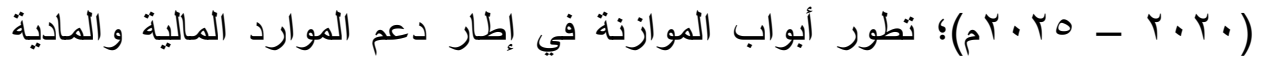

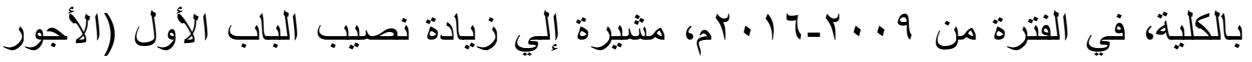


إدارة أولويات برنامج الابلوم العام في التربية بجامعة الأزهر في ضوء ملخل المقارنة المرجعية benchmarking

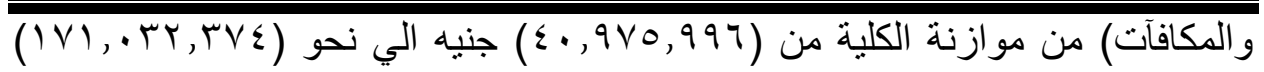

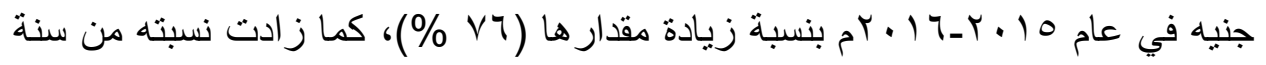

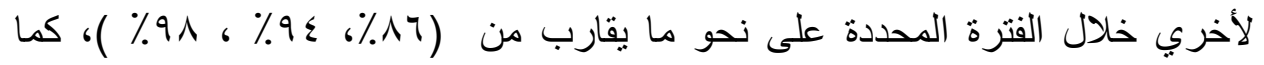
أوضحت وجود تناقص فيما يختص بالباب الثاني و الرابع بالمقارنة بالباب الأول؛ حيث

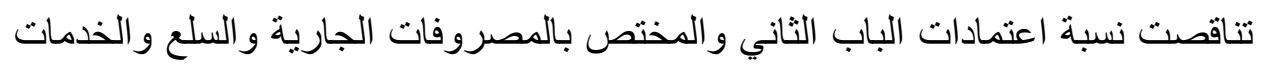
مثل الإيجار ات و الصيانة و الإنارة وتكاليف التغذية و غير ها من أوجه الأنفاق الجاري من

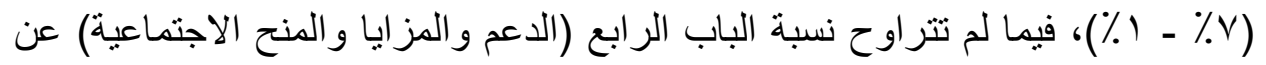

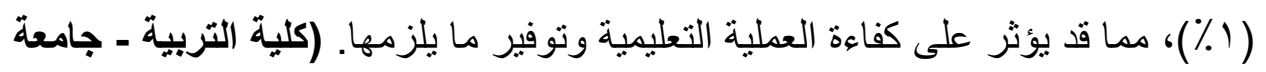

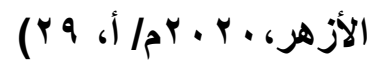
V. مشاركة القيادات الأزهرية ودعمها لإدارة البرنامج

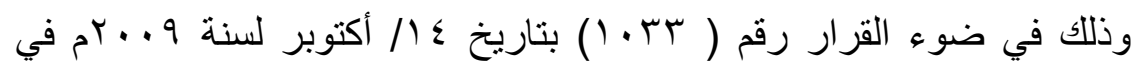
شأن نظام إدارة برامج التأهيل التربوي، وتنشكيل اللجنة العليا للإشراف على البرنامج

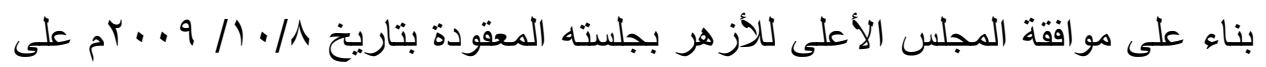

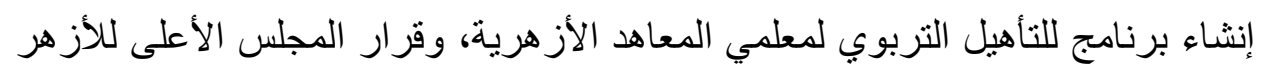

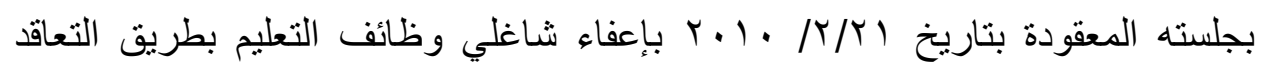
بالمعاهد الأزهرية الدارسين بكلية التربية بنين بجامعة الأزهر أو أحد المر اكز التابعة لها باعلاهي

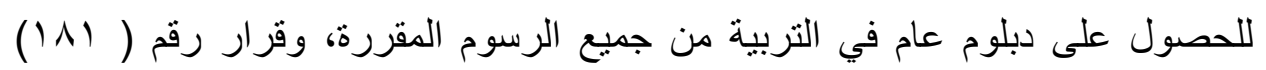

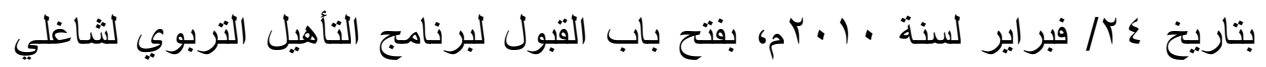
وظيفة معلم مساعد أو أخصائي مساعد أو أخصائي نفسي مساعد أو أمين مكتبة مساعد

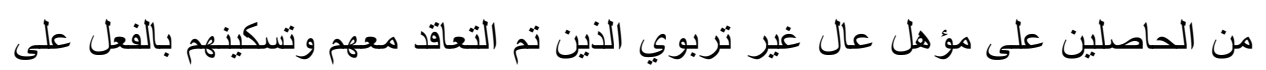
هذه الوظائف بعد اجتياز هم الاختبار ات المقررة- لنيل الدبلوم العام في التربية وذلك دون التقبد بشرط السن أو تاريخ الحصول على المؤهل العالي أو المجموع الكلي للارجات

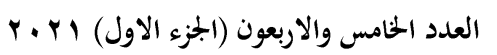

مجلة كلية التربية- جامعة عين شمس 
د/ أحمد عبد القتاح حمدي الهنداوي

وذلك للتعين في وظيفة معلم مساعد أو أخصائي مساعد أو أخصائي نفسي مساعد أو

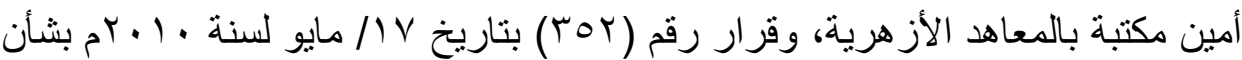
تشكيل اللجان المختصة بإدارة وتنفيذ برنامج التأهيل التربوي لمعلمي المعاهد الأز هرية.

\section{م. أعضاء هيئة التدريس والهيئة المعاونة}

يتو افر قدر مناسب من القوى بشرية ممثلة في أعضاء هيئة التدريس والهيئة المعاونة بالكلية، باعتبار هم محور وأساس كل تطوير على مستوى المنظومة التعليمية بالجامعة، ويوضح الجدول التالي أعداد أعضاء هيئة التدريس ومعاونيهم بكلية التربية

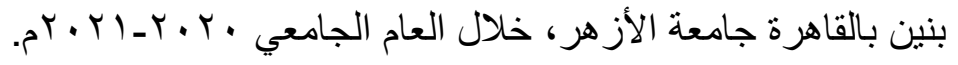

جدول (ع) أعداد أعضاء هيئة التدريس (عامل، متفرغ) ومعاونيهم بكلية التربية

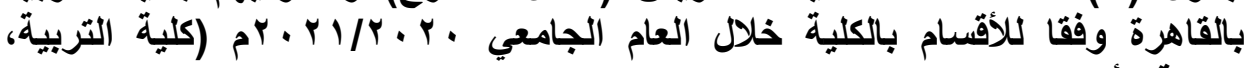

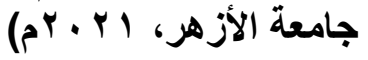

\begin{tabular}{|c|c|c|c|c|c|c|c|c|c|}
\hline & \multicolumn{3}{|c|}{ الهيئة المعاونة } & \multicolumn{4}{|c|}{ أعضاء هيئة التدريس } & \multirow{2}{*}{ القســـــم } & \multirow[b]{2}{*}{ s } \\
\hline عام & اجمالح & مدرس & 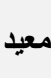 & اجمالي & مدرس & م أستاذ & أستاذ أ & & \\
\hline 0 \& & $r$ & $1 \mathrm{~V}$ & 7 & M & $\Lambda$ & $\Lambda$ & 10 & علم النفس التعليمي & 1 \\
\hline 1.0 & $\leqslant 9$ & $\varepsilon \mu$ & 7 & 07 & H & $1 \varepsilon$ & rq & المناهج وطرق التدريس & r \\
\hline or & rq & r & 7 & $r \leq$ & 7 & 7 & ir & الادارة والتخطيط & r \\
\hline$\varepsilon V$ & rr & $1 \mathrm{~V}$ & ○ & ro & V & $r$ & 10 & اصول التربية & $\xi$ \\
\hline$\varepsilon V$ & Y & $1 \mathrm{~V}$ & $\varepsilon$ & Y & 9 & 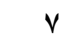 & 1. & الصحة النفسية & 0 \\
\hline $1 \wedge$ & $\Lambda$ & r & 7 & 1 . & 9 & 1 & - & التربية الفتية & 7 \\
\hline r & Ir & 9 & $r$ & Y & 10 & $\bullet$ & 7 & تكنولوجيا التعليم & V \\
\hline קo & ro & 19 & 7 & 1. & $r$ & $\varepsilon$ & $r$ & التربة الاسلامية & $\wedge$ \\
\hline rr & $1 \varepsilon$ & 11 & $\mu$ & 11 & $\Lambda$ & 1 & 9 & الخدمة الاجتماعية & 9 \\
\hline 17 & - & - & - & 17 & V & r & V & الدر اسـات الاسلامية & 1 . \\
\hline$\leqslant \leqslant 0$ & $r \cdot r$ & 101 & $\leqslant 0$ & $r \leqslant r$ & 10 & 01 & 1.7 & & \\
\hline
\end{tabular}

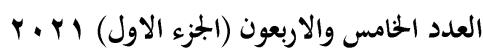

(55)

مجلة كلية التربية- جامعة عين شثس 
إدارة أولويات برنامج الابلوم العام في التربية بجامعة الأزهر في ضوء ملخل المقارنة المرجعية benchmarking

ومن خلال الجدول السابق يتضح أن الكلية يتوفر بها قوة عمل أكاديمية كبيرة

موزعة علي الأقسام العلمية بالكلية (أصول التربية ـ الإدارة والتخطيط والدراسات المقارنة ـ التربية الإسلامية ـ المناهج وطرق التدريس - علم النفس التعليمي ـ الصحة التهد النفسية ـ المكتبات وتكنولوجيا التعليم ـ الخدمة الاجتماعية ـ الدراسات الاسلامية هنية التربية الفنية )، ومن ثم تعد مقوماً أساسيا يمكن استتماره في إدارة أولويات برنامج الدبلوم العام في التربية في ضوء مدخل المقارنة المرجعية. 9. توافر وحدة للتعليم الإككتروني والتعلم عن بُعد بالكلية

تستهدف هذه الوحدة؛ دعم ومساندة أعضاء هيئة التدريس و الطلاب في تحسين مخرجات التعلم، وتحويل مقرراتها التعليمية إلي مقررات إلكترونية، بما يؤدي إلي تعميق المفاهيم والنهوض بمستوى التعليم، وتتجيع التميز في مجالات التدريس وسهولة التعامل مع التقنيات الحديثة، وتتمثل رؤية الوحدة في "توفير خدمات إلكترونية متطورة ومتنوعة ومتميزة لكافة المستفيدين (المعنيين) من التعليم، ونشر ثقافة التعليم الإلكتروني

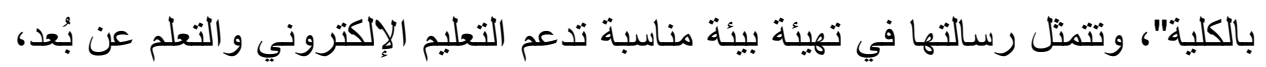
من خلال تتجيع أعضاء هيئة التدريس ودعمهم، وتحفيز الطلاب علي إجادة التقنيات

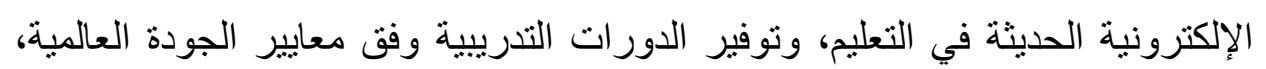

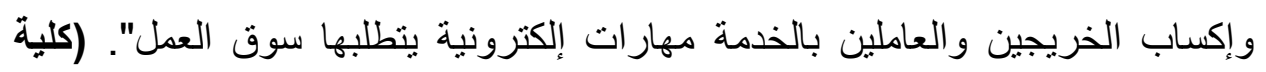

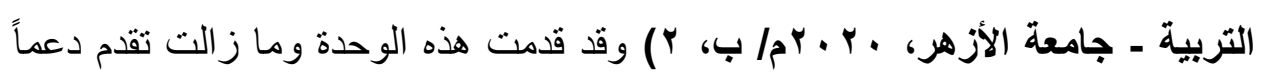
فنياً لكافة البر امج الأكاديمية بالكلية. • إ. اهتمام جامعة الأزر بالتميز الدولي بذلت جامعة الأزهر العديد من الجهود لرفع جودة وتميز الأداء المؤسسي بها، متمثلة في إنشاء مكتب جامعة الأزهر للتميز الدولي، حيث تم تخصيص جز هُ من ميز انية

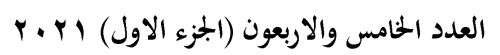

(56)
مجلة كلية التربية- جامعة عين شنم 


\section{د/ أحمد عبد الفتاح حمدي الهنداوي}

الجامعة لاعم إجر اءات التميز المؤسسي، كوسيلة فعالة لتحقيق سياساتها في تحسين جودة المباد مخرجاتها التعليمية، ومواكبة الاتجاه العالمي المتزايد نحو تطبيق أبرز نماذج التميز العالمية، ويتمثل توجها الاستراتيجي فيما يلي: (جامعة الأزهر - مكتب التميز الدولي،

$$
\left(b^{r} \cdot 19\right.
$$

- تتمثل رؤية مكتب جامعة الأزهر للتميز الدولي في "أن تكون جامعة الأزهر منارة العلم و المعرفة، ولها الريادة والتميز في التصنيف الدولي للجامعات. وتتمثل رسالته

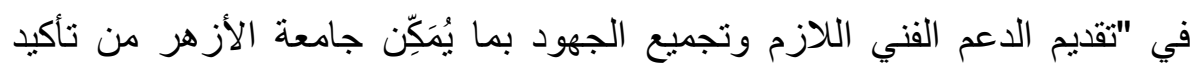
ريادتها في تقديم الخدمات التعليمية والبحث العلمي وخدمة المجتمع، وتعزيز قنوات التعاون الأكاديمي والثقافي و العلمي بين الجامعة والكيانات المحلية والدولية، في إطار العمل نحو تأكيد ريادة الجامعة بين الجامعات العربية والإسلامية والعالمية". - ويستهف مكتب جامعة الأز هر للتميز الدولي؛ تأكيد عالمية جامعة الأزهر وريادتها في العلوم الثرعية والعربية، والإنسانية والاجتماعية، و العلوم التطبيقية، وذلك من خلال العديد من الأهداف الإجرائية، من أبرز ها: إنشاء علاقات متميزة مع الجامعات و المؤسسات الدولية لإبرام وتفعيل اتفاقيات التعاون المشترك في شنى المجالات، وتتجيع المنح والبعثات للطلاب وأعضاء هيئة التدريس المصريين والوافدين، وتوفير خدمات واستشارات فنية لمنسوبي الجامعة والمجتمع في جوانب التميز، و الترويج الإعلامي لمواطن التميز بالجامعة محليا و إقليميا ودوليا، وإتاحة خدمات إلكترونية متقدمة ومتطورة في كل الجالات على موقع البوابة الإلكترونية الرسمية للجامعة، وتقديم بر امج تدريبية مختلفة لمنسوبي الجامعة مثل النشر الدولي، وكتابة مقترحات التقدم للمنح الدولية والمشرو عات، وتبادل المشرو عات الأكاديمية و غير ها. من خلال ما سبق يتضح أن هنالك العديد من المقومات الأساسية، التي تشكل منطلقاً لإدارة أولويات برنامج الدبلوم العام بجامعة الأزهر في ضوء هد مدخل المقارنة 
إدارة أولويات برنامج الابلوم العام في التربية بجامعة الأزهر في ضوء ملخل المقارنة المرجعية benchmarking

المرجعية، بما يُسهم في التعامل مع ما تواجهه مؤسسات التعليم الأزهري من تحديات، تتمثل أبرزها في زيادة حدة المنافسة بين المؤسسات الجامعية، و العولمة، والانفجار مئه المعرفي، والتقدم العلمي و التكنولوجي المستمر، بالإضافة إلي تدني النظرة المجتمعية نحو التعليم الأزهري وخريجو الأزهر، حيث ينظر إليه البعض علي أنه ما زال أقل بله كفاءة في إعداد خريجيه مقارنة بالتعليم العام، وعزوف بعض الإن الأفراد عن التحاقهم

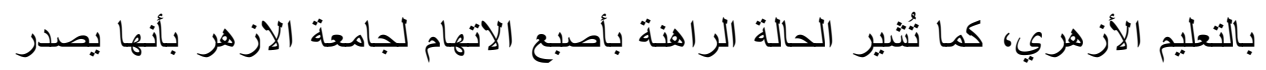

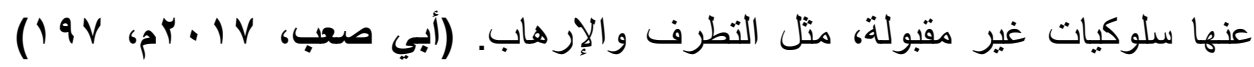

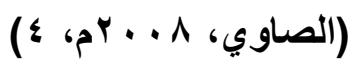

و علي الجانب الآخر؛ يقدم برنامج الدبلوم العام في التربية بجامعة الأزهر خدمة

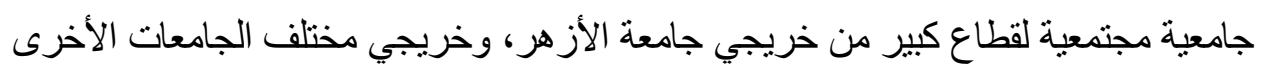

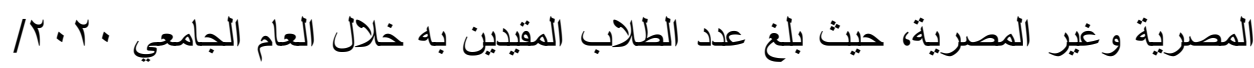

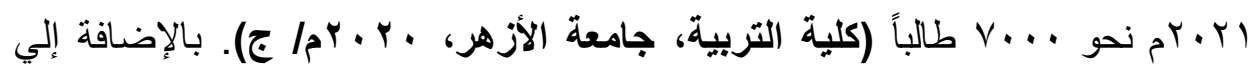

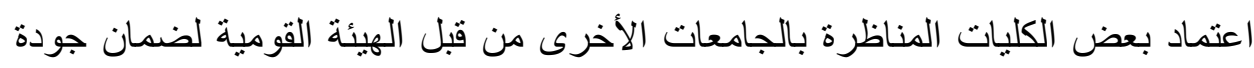
التعليم والاعتماد، والتي تقدم برامج مماثلة لإعداد المعلمين في البيئة المصرية، مثل بـل كليات التربية بجامعات (أسيوط - الوادي الجديد ـ الفيوم ـ عين شمس)، واعنماد

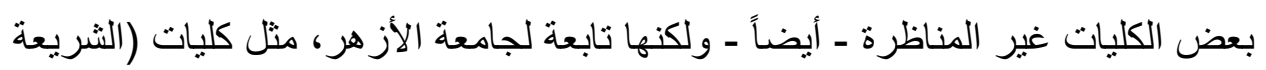
والقانون بطنطا ـ اللغة العربية بإيتاي البارود- أصول الدين بالمنوفية ـ العلوم بنين

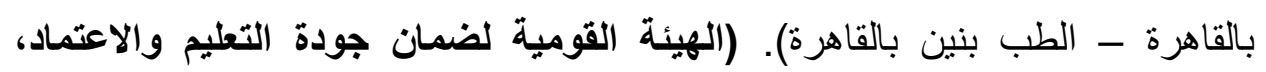

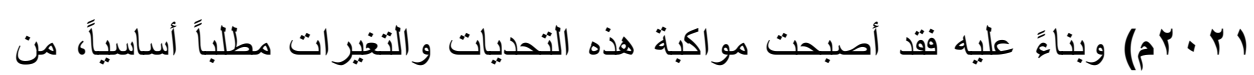
خلال تبني مداخل إدارية جديدة تقودها نحو إيجاد استراتيجيات تضمن لها البقاء و الاستمر ارية وتحقق ميز اتها التنافسية.

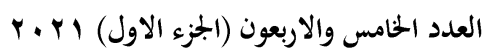

(58)
مجلة كلية التربية- جامعة عين شثس 
د/ أحمد عبد الفتاح حمدي الهنداوي

ثُالثاً: أفضل الممارسات العالمية في تطوير برامج إعداد المعلمين

تشهد بعض المنظمات العالمية والمؤسسات المهتمة والمعنية بالتعليم؛ اهتماماً

بالغاً بتحديد أفضل الممارسات في إعداد وتكوين معلم القرن الحادي والعشرين، ومن أبرز هذه المنظمات والمؤسسات؛ البنك الدولي ومنظمة التعاون الاقتصادي والتنمية، و اليونسكو ومراكز الأبحاث المتخصصة في مجال تصميم أفضل الممارسات، حيث تسعى لتقديم نماذج مصممة، من أحل تعظيم الاستفادة من حلول تم تجربتها وتطبيقها في أماكن ومؤسسات أخرى، بما بمثل المشاركة في المعرفة والحلول مع الآخرين بدلًا من إعادة البحث عن حلول من جديد، بما يوفر الوقت والجهد، وذلك مع مراعاة تكييف و انسجام الممارسات المتميزة مع البيئة المحيطة. وقد تم تصنيف كل من: فنلندا ، وسنغافورة ، وكندا، و الصين، وكوريا الجنوبية، على أنهم من أفضل الممارسات العالمية؛ وذللك لأنهم ركزوا على القضايا التعليمية المتعلقة بتطوير الإعداد الأولي ومعايير الجودة والاعتماد لمعلم القرن الحادي و العشرين، والمنمنلة في: المؤهلات، و عدد سنوات الدراسة، و المؤسسة المسئولة عن الإعداد، والمقررات الدراسية التي يتم تقديمها، و التدريب الميداني. لذلك صنفت تللك الدول على أنها تقدم أفضل الممارسات العالمية في مجال الإعداد الأولي ومعايير الجودة و الاعتماد لمعلم القرن الحادي و العشرين. (Mullis, Ina VS, et al, 2012) وتسعى برامج إعداد المعلمين في فنلندا إلى تحقيق التنمية في الكفاءات الثخصية والمهنية للمعلم بشكل متوازن، وتركز الاهتمام بشكل خاص على بناء مهارات التفكير التربوية التي تمكن المعلمين من إدارة العملية التعليمية بما يتفق مع المعرفة التعليمية والممارسات المعاصرة للبرنامج، ويدرس المرشحون للتعليم في المدارس الأساسية ثلاث مجالات رئيسية هي: "نظرية التعليم - معرفة المحتوى التربوي - فن

التعليم و الممارسة". (Westbury, et. All, 2005, 475)

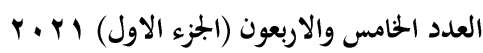

(59)
مجلة كلية التربية- جامعة عين شثس 
إدارة أولويات برنامج الابلوم العام في التربية بجامعة الأزهر في ضوء ملخل المقارنة المرجعية benchmarking

وتتميز برامج إعداد المعلمين الفنلندية - من خلال المقارنات الدولية - بعمق دراهن

أهدافها، إذ أن التكامل بين التطبيق النظري والعملي في هذه البرامج يساعد المعلمين على إتقان أساليب تدريس مختلفة، وكذلك تعلم فن التدريس و التعليم الفعال، وخلال البرنامج الذي يستمر لمدة خمس سنوات، يطلع الطلاب على فصول تدرس من قبل معلمين ذوي خبرة، ويمارسون التدريس تحت أنظار المعلمين المشرفين، وتقديم دروس مستقلة لمجموعات مختلفة من التلاميذ بينما يتم تقييمه من قبل المشرفين و المحاضرين من وزارة التربية والتعليم، وكثف إصلاح المناهج الدر اسية في منتصف التسعينيات أن المعلمين ذوي الكفاءة المهنية العالية يمتلكون دوافع للانخراط في عمليات التنمية المدرسية في المدارس التي يعملون فيها وكذلك في المشاريع الوطنية والدولية، وتبين أنهز يميلون إلى العمل بجد على تطوير معرفتهم الثخصية ومهاراتهم المهنية.(Jussila \& Saari 2000)

وتركز برامج إعداد المعلمين في فنلندا على الربط الوثيق بين النظريات التربوية ذات الطابع العلمي المنهج، والخبرات العملية التطبيقية الأنشطة التربية العملية، ويمكن التمييز بدقة بين نمطين رئيسيين من أنشطة التربية العملية التي يشارك فيها

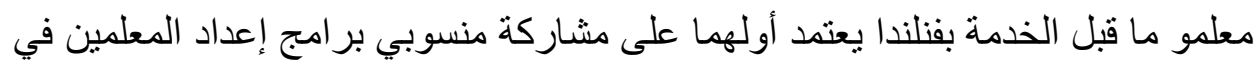

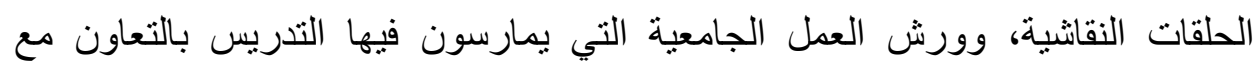
زملائهم الآخرين. أما النمط الثاني، فيطبق عادة على مستوى الكليات الجامعية المتخصصة في مجال إعداد المعلمين عبر تزويد منسوبي برامج إعداد المعلمين بمناهج و مقررات دراسية، وممارسات تدريسية تشبه كثثرا غير ذلك من المدارس العامة

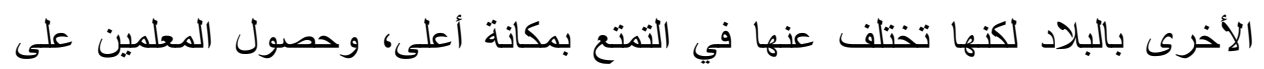
رواتب مالية مجزية مقابل عملهم بالتدريس؛ الأمر الذي يعكس بدوره حقيقة أن خدمات التوجيه والإرشاد المهني التي يقدمها المشرفون التربويون من معلمي المدارس لأقرانهم

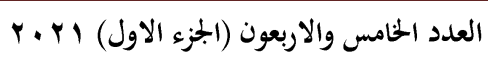

$$
\begin{aligned}
& \text { مجلة كلية التربية- جامعة عين شثس }
\end{aligned}
$$


د/ أحمد عبد الفتاح حمدي الهنداوي

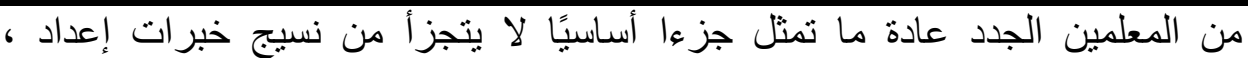

وتدريب معلمي ما قبل الخدمة. ول (Sahlberg, P. 2010b) (Sahlberg, P.

2010a)

و في سنغافورة يسعى المعهد الوطني للتعليم إلي تطبيق توجهات مستقبلية

وطرقاً تربوية جديدة، حيث يقوم بتنمية قدرات معلمي القرن الحادي والعشرين في "التعليم القائم علي حل المشكلات"، من خلال منهجية تمر بخمسة مراحل، أولها: مواجهة المشكلة، ويتم فيها تناول سيناريوهات التعامل مع الحقائق الكونية. وثانيها: تحليل المشكلة، ويتم فيها تناول مناقتنة وتحليل الحقائق والأفكار، وتوقع التفسيرات المستقبلية. وثالثها: الاكتشاف والإبداع، ويتم فيها تناول الحلول الممكنة والتعامل معها على أنها معلومات جديدة أبصرت النور.ورابعها: عرض الحلول، ويتم فيها تناول عرض الحلول والنتائج على المجموعات الأخرى. وخامسها: التقييم، ويتم من خلالها التفكير بالعملية ككل مع التركيز على النقاط الأساسية التي قادتهم نحو الحل.

كما تم تصنيف برنامج التوجيه والمتابعة في سنغافورة وفق تقرير منظمة التعاون الاقتصادي talis على أنه من أفضل الممارسات العالمية في مجال التوجيه و المتابعة باستمرار حيث إنه يرتكز على ثلاثة أسس وهي: التواصل المباثر بين المرشد العمي والطالب المعلم، والملاحظات البناءة، واتباع منهج منظم للإرشاد مع تخفيف عبء العمل عن المتدرب أثناء عملية التدريب، ويتابع أداء المعلمين المتدربين مسئولين عن كل مرحلة ومنسقي المواد ورؤساء الأقسام، ويتم التدريب على مرحلتين التدريب

العام والتدريب المتخصص Ministry of Education - Singapore)

\section{5) (OECD 2015)}

وطبقت الجامعات الصينية توجهات مستقبلية وطرقا تربوية جديدة، حيث يقوم بتنمية قدرات معلمي القرن الحادي والعشرين في "تعزيز المواقف الإيجابية، وتأكيد 
إدارة أولويات برنامج الابلوم العام في التربية بجامعة الأزهر في ضوء ملخل المقارنة المرجعية benchmarking

آليات التفكير الاجتماعي والثقافي، والتي أبرزها: التعليم القائم على مجتمعات التعلم المفتوحة، والتفكير التأملي"، ونم تصنيف برنامج مجتمعات التعلم في ولاية شنغهاي الصينية وفق تقرير منظمة التعاون الاقتصادي talis على انه من أفضل الممارسات العالمية في مجال تنظيم مجتمعات التعلم المفتوحة المشتركة، والحفاظ على استمر اريتها، وذلك من خلال إنشاء شبكة للمعمين منذ عام 1998 م والتي تطورت بعد ذلك لتصبح أكاديمية المعلمين، وتتم مجتمعات التعلم في المدارس بالإضافة إلى التواصل من خلال شبكات الإنترنت لتبادل المعارف، ونجحت ولاية شنغهاي من خلال هذا البرنامج؛ لأنها استطاعت أن تجد حلو لا للمشاكل الثائعة من خلال تفعيل أفضل الممارسات.

كما تم تصنيف برنامج حلقات البحث في ولاية هونج كونج وفق تقرير منظمة التعاون الاقتصادي talis على أنه من أفضل الممارسات العالمية في مجال حلقات البحث؛ حيث يتم تشجيع الطلاب المعلمين على تعزيز الممارسات التعليمية من خلال (Ministry of Education - بلورة تجاربهم في صورة مقالات أكاديمية

China 2015) (OECD 2015)

وتم تصنيف برنامج أونتاريو الجديد لإعداد المعلم وفق تقرير منظمة التعاون الاقتصادي talis على أنه من أفضل الممارسات العالمية في مجال الإعداد والتدريب التمهيدي للمعلمين؛ لكونه برنامج شامل ومتكامل في توجيه ومتابعة المعلمين، وتنطلق فلسفته من أن مرحلة الإعداد أو التدريب التمهيدي هي المرحلة الأولى من عملية التدريب أثناء الخدمة؛ ولذلك يتم البرنامج من خلال تقديم الدعم المستمر، والإرشاد و التدريب المناسب لكل مرحلة، ويشمل البرنامج التدريب على الإدارة الصفية وآليات التواصل مع أولياء الأمور، ومدة البرنامج سنة واحدة، ولكن يستمر التوجيه حتى بعد انتهاء مده البرنامج (Ministry of Education - Canada 2015)

(OECD 2015)

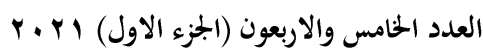

(62)
مجلة كلية التربية- جامعة عين شثس 
د/ أحمد عبد الفتاح حمدي الهنداوي

وتعتمد بر امج إعداد المعلمين في و لاية أونتاريو بكندا على وجود معايير للمهنة

محددة بدقة ومقننة، وتُعتبر موجهة ومرشدة للمهنة، وقامت كلية المعلمين بأونتاريو بوضع خمسة معايير مهنية للمعلمين هي: الالتزام بتعليم وتعلم الطلاب، والمعرفة المهنية، و الخبرات والممارسات المهنية، والقيادة في مجتمعات التعلم، و التعلم المهني المستمر. (OECD, 2013, 25) ويوجد العديد من المؤسسات التي تقوم بإعداد المعلم

وهي: (CMEC, 2012, 4-5)

- University of معهد أونتاريو للدراسات التربوية في جامعة تورونتو:

Toronto

- - مركز تعليم منطقة باي: Bay Area Learning Centre - ملية التربية في جامعة ليكهيد: Lakehead University - - كلية التربية في الجامعة الملكية: Queen's University - الكلية الجامعية بريدمير: Redeemer University College - كلية التربية في جامعة بروك: Brock University - كلية التربية بجامعة أوتاوا: University of Ottawa - كلية التربية بالجامعة الغربية: Western University - كلية التربية بجامعة وندسور: University of Windsor - كلية المدارس المهنية بجامعة لور انس: Laurentian University - ق قسم التربية بجامعة نياجار ا: Niagara University. - Sلية التربية بجامعة نيبسينج : Nipissing University - كلية التربية والتعليم المهني بجامعة ترينت : كrent University -

- كلية التربية بجامعة تيندال : Tyndale University - كلية التربية بمعهد جامعة أونتاريو للتكنولوجيا: Institute of Technology

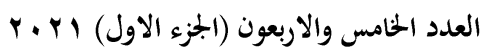

مجلة كلية التربية- جامعة عين شثس 
إدارة أولويات برنامج الابلوم العام في التربية بجامعة الأزهر في ضوء ملخل المقارنة المرجعية benchmarking

\section{- ملية التربية بجامعة ويلفريد لورييه: Wilfrid Laurier University \\ - لية التربية بجامعة يورك: York University}

وقامت وزارة التربية بولاية أونتاريو بكندا بوضع مجموعة من المعايير المهنية

Ontario College للمعلمين وهي مستمدة من معايير كلية المعلمين بو لاية أونتاريو of Teachers، وتوفر هذه المعايير إطاراً من المبادئ التي توضح المعارف و المهارات والقيم المُتأصلة في مهنة التدريس في أونتاريو، وتبين هذه المعايير أهداف هندي وتطلعات المهنة، وتهدف هذه المعايير إلى تحديد القيم والمعارف والمهارات التي تميز مهنة التدريس، وتوجيه وإرشاد للإجر اءات القيمية والأخلاقية لمهنة التدريس، وتعزيز لغة وفهم مشترك لما تعنيه مهنة التدريس، والحفاظ على شرف وكر امة مهنة التدريس و الاعتزاز بالانتماء إليها، وتدعيم ثقة الجمهور والمجتمع في مهنة التدريس. وأثنار

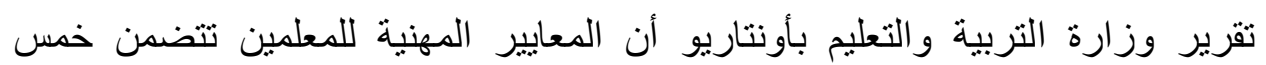

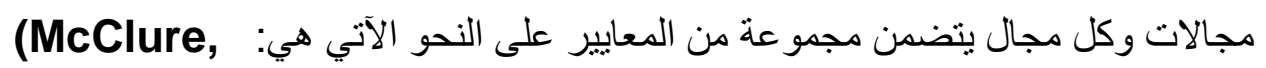

2008, 182)

- الالتزام نحو التلاميذ وتعلمه: Commitment to Pupils and Pupil Learning المستمرة - يلتزم المعلمون في جهودهم إلى تعليم ودعم تعلم و إنجاز التلاميذ - يلتزم المعلمون بمعاملة جميع التلاميذ بعدالة و إنصاف واحتر ام - يوفر المعلمون بيئة للتعلم تشجع التلاميذ على حل المشكلات وصنع القرار والتعلم مدى الحياة والمساهمة كأعضاء فاعلين في إحداث التغيير المجتمعي).

- المعرفة المهنية: Professional Knowledge ويتضمن هذا المجال المعايير الآتية: (يعرف المعلمون موضوعات المناهج الدراسية في ولاية أونتاريو

مجلة كلية التربية- جامعة عين شمس 
د/ أحمد عبد الفتاح حمدي الهنداوي

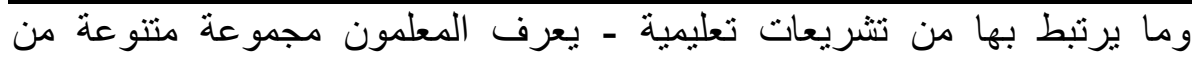
الممارسات التعليمية والتقويمية الفعالة - يعرف المعلمون مجموعة متنوعة من استر اتيجيات الإدارة الصفية الفعالة ـ يعرف المعلمون كيف يتعلم التلاميذ و العوامل التي تؤثر في تعلمهم و إنجاز هم.

- خبرات وممارسات التدريس: Teaching Practice، ويتضمن هذا المجال المعايير الآتية: (يستخدم المعلمون معرفتهم المهنية والمناهج و التشريعات والممارسات التعليمية والإدارة الصفية لتعزيز تعلم التلاميذ وإنجازهم - يتواصل المعلمون بشكل فعال مع التلاميذ وأولياء الأمور و الزملاء - يُجري المعلمون تقويماً مستمراً لمستويات إنجاز وتقدم التلاميذ، وإعداد تقارير بذلك وتسليمها للطلاب وإرسالها لأولياء أمورهم - يُكيف المعلمون ويصقلون ممارساتهم التدريسية من خلال التعلم والتفكير والتأمل المستمر، وذللك باستخدام مجموعة متنوعة من المصادر والموارد - يستخدم المعلمون التكنولوجيا المناسبة في ممارساتهم التعليمية وما يتصل بهم من ممارسات مهنية.

- القيادة والمجتمع: Leadership and Community، ويتضمن هذا المجال المعايير الآتية: (يتعاون المعلمون مع هيئة العاملين بالمدرسة لإيجاد مجتمعات تعلم والحفاظ عليها في فصولهم ومدارسهم - يعمل المعلمون مع أعضاء المجتمع الخارجي وأولياء الأمور لتعزيز تعلم التلاميذ و إنجاز هم وتعزيز البرامج المدرسية). - التعلم المهني المستمر: Ongoing Professional Learning، ويتضمن هذا المجال المعيار الآتي: (ينخرط المعلمون في التعليم المهني المستمر وتطبيقاته لتحسين ممارساتهم التدريسية).

و وأثنارت وثنائق وتقارير Ministry of Education - Singapore 2017) (OECD 2013) (Ministry of Education - Canada 2017) 
إدارة أولويات برنامج الدبلوم العام في التربية بجامعة الأزهر في ضوء مدخل المقارنة المرجعية benchmarking

تصنيف كل من: فنلندا ، وسنغافورة ، وكندا، و الصين، وكوريا الجنوبية، على أنهم من

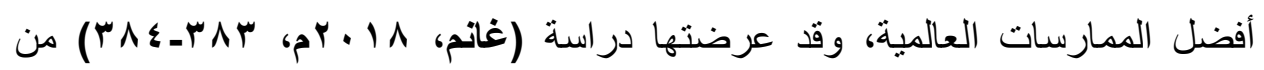

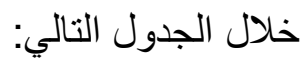

جدول (0) برامج إعداد المعلمين في كل من "فنلندا ، وسنغافورة ، وكندا، والصين،

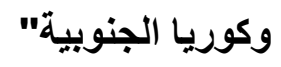

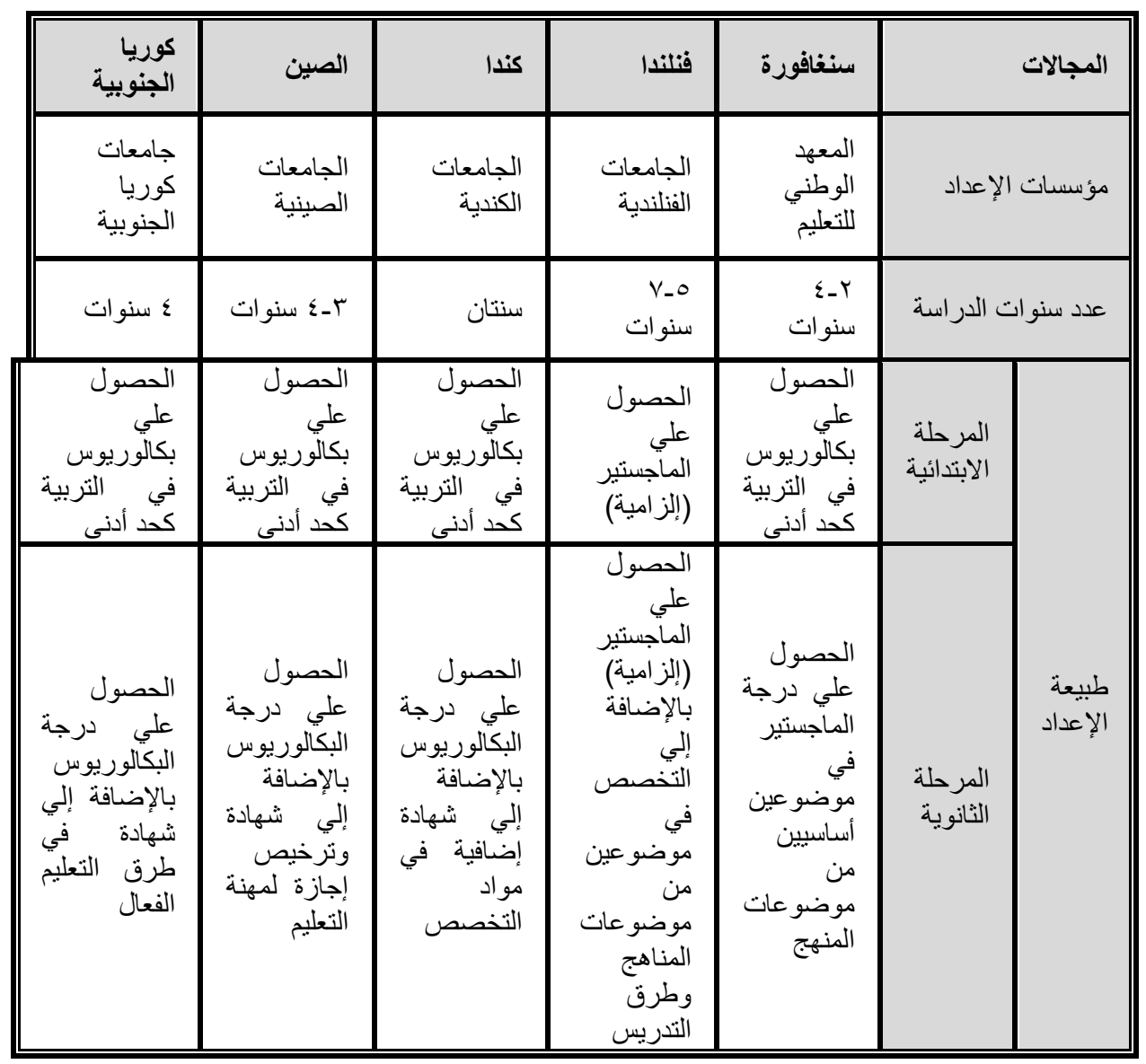

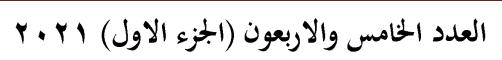

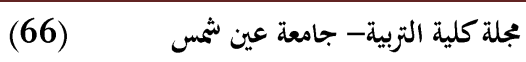


د/ أحمد عبد الفتاح حمدي الهنداوي

\begin{tabular}{|c|c|c|c|c|c|}
\hline 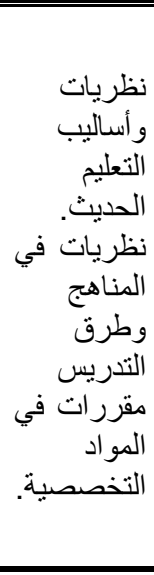 & 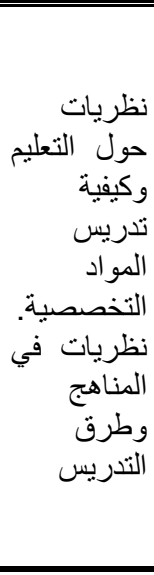 & 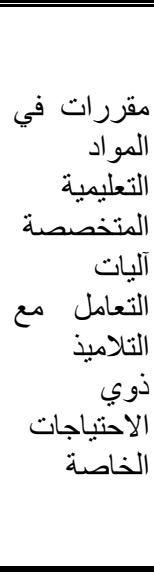 & 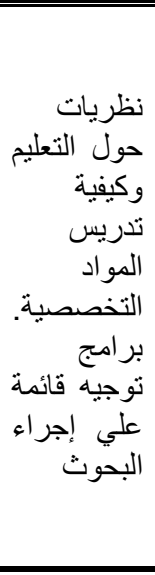 & 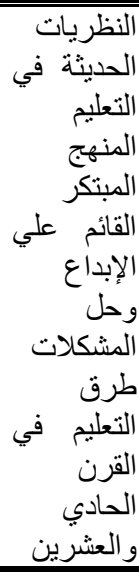 & المقررات الدراسية \\
\hline 9 أسابيع & ^ أسابيع & 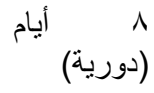 & كامل دراسي & •ا أسابيع & ب الميداني \\
\hline
\end{tabular}

ومن خلال ما سبق يتضح أن تلك الممارسات تم وصفها بأفضل الممارسات؛ لأنها تأخذ بعين الاعتبار مضدون المقررات الدراسية، أي الاهتمام بالمعارف و المحتوى و التدريب على أساليب التعليم مع ضرورة تأكيد الدمج بين النظرية و التطبيق، و لا بد أن يتم ذلك من خلال تدريب المعلمين الجدد تدريجيًّا على المعايير العالية و على الممارسات

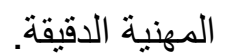

ويوجد في الولايات المتحدة الأمريكية العديد من المؤسسات القائمة على عمليات الاعتماد والاعتراف بمؤسسات إعداد المعلم، ويمثل المجلس الوطني لاعتماد National Council for Accreditation of مؤسسات إعداد المعلمين (NCATE) Teacher Education في الولايات المتحدة الأمريكية، وهناك مؤسسات خاصة بإعتماد برامج اعداد المعلم ، ويمثل مجلس اعتماد المعلم Teacher Education Accreditation Council الجهة المسئولة عن اعتماد بر امج إعداد المعلم بالولايات المتحدة الأمريكية. وفي نوفمبر • ا• بام اندمجت مؤسسة (NCATE) مع مجلس اعتماد معلم التربية لتصبح مؤسسة واحدة هي مجلس اعتماد إعداد المعلمين (CAEP) (TEAC)

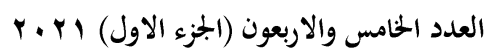

مجلة كلية التربية- جامعة عين شمس 
إدارة أولويات برنامج الابلوم العام في التربية بجامعة الأزهر في ضوء ملخل المقارنة المرجعية benchmarking

ونتيجة (Council for the Accreditation of Educator Preparation) لهذا الاندماج ظهرت المعايير الخمسة CAEP والمتمثلة في: "المحتوى المعرفي و التربوي - الثر اكة المهنية و الممارسات الميدانية - جودة المرشح من حيث الاستقطاب والاختيار - تأثير البرنامج - ضمان جودة البرنامج والتحسين المستمر". (العاني و (National Council for Accreditation of (r) ( Teacher Education, 2002, 1) و هناك مؤسسات خاصة بمنح شهادات وتراخيص العمل بمهنة التدريس بالولايات المتحدة الأمريكية، ومنها: اتحاد تقييم ودعم المعلم بين الولايات INTASC: Interstate Teacher Assessment and (INTASC) Support Consortium وقد تم إنشاء هذا الاتحاد عام 9NV ام، من أجل تعزيز التعاون بين الولايات التي تهتم بإعادة النظر في الترخيص للمعلمين بممارسة المهنة وتقييم من يعمل في مهنة التدريس، وفي عام بو9 ام وضع الاتحاد عددا من المعايير النموذجية التي تصف ماذا يجب أن يعرفه ويقوم به المعلمون الجدد، وتتوافق هذه المعايير للمعلمين الجدد لجميع المواد الدراسية وعلى كل المستويات مع ثللك المعايير الخاصة بالثهادات التي اقترحها المجلس القومي لمعايير التدريس المهنية (NBPTS) (Interstate New Teacher Assessment and Support Consortium 2019) ويضم هذا الاتحاد rr و ولاية، ويضع مجموعة من المبادئ

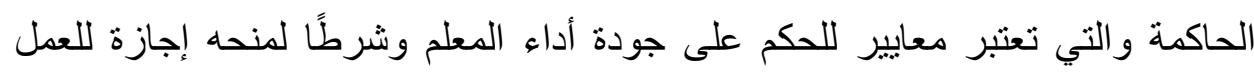

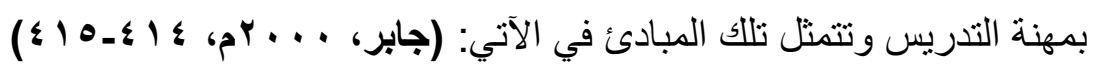
- أن يفهم المعلم المفاهيم الرئيسية، وأدوات البحث و الاستقصاء، والعلوم والمواد التي

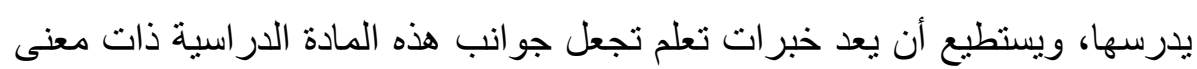
للتلميذ.

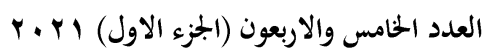

(68)
مجلة كلية التربية- جامعة عين شثس 
د/ أحمد عبد الفتاح حمدي الهنداوي

- - أن يفهم المعلم كيف يتعلم الأطفال وكيف ينمون، وأن يستطيع أن يوفر فرص ألعلم تساند نمو هم العقلي و الاجتماعي و الثخصي.

- أن يفهم المعلم كيف يختلف التلاميذ في مداخلهم للتعلم وأن يوفر ويخلق الفرص التعليمية التي تلائم المتعلمين.

- أن يفهم المعلم استراتيجيات تدريس متنوعة وأن يستخدمها لمساعدة التلاميذ على تتمية التفكير الناقد وحل المشكلات ومهار ات الأداء.

- أن يستخدم المعلم فهمه لدافعية الفرد والجماعة ولسلوكهما لخلق بيئة تعلم تشجع التفاعل الاجتماعي الإيجابي والاندماج النشط في التعلم و الدافعية النابعة من الذات. - أن يستخدم المعلم معرفته بأساليب التواصل الفعالة لتنمية البحث والاستقصاء والتعاون و التفاعل الداعم داخل حجرة الدراسة. - أن يكون تخطيط المدرس للتعليم مستندًا إلى معرفته بالمادة الدراسية والتلاميذ و المجتمع المحلي وأهداف المنهج التعليمي. - أن يفهم المعلم استراتيجيات التقييم النظامية وغير النظامية وأن يستخدمها في تقويم نمو المتعلم العقلي والاجتماعي والجسمي. - أن يكون المعلم ممارس ومفكر متأمل يقوم بشكل مستمر تأثير اختيار اته وأفعاله على الآخرين ويبحث عن الفرص التي تنميه مهنيًا. - أن ينمى المعلم العلاقات مع زملائه في المدرسة ومع الآباء، ومع المؤسسات الأخرى في المجتمع المحلي لمساندة تعلم التلاميذ.

وتعتمد معايير المجلس الوطني لاعتماد مؤسسات وبر امج إعداد المعلم في في

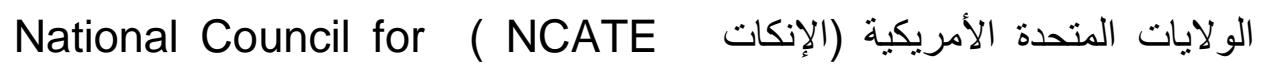
Accreditation Teacher Education الممكن ، بل ومن الضروري أن يتعلمو ا ؛ومن ثم يكون من العدالة أن يتو افر لهم جميعًا

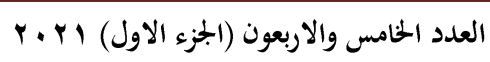

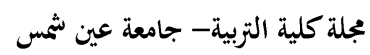


إدارة أولويات برنامج الابلوم العام في التربية بجامعة الأزهر في ضوء ملخل المقارنة المرجعية benchmarking

أعضاء هيئة التنريس مؤهلين وقادرين على المنافسة بالإضافة إلى مجموعة من العاملين

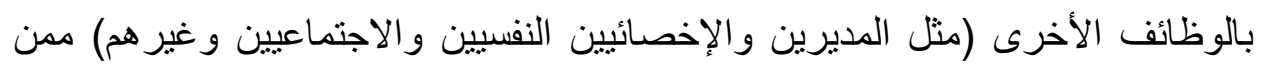
تتوافر لديهم القدرة على تعزيز تعلم الطالب وإكسابه المهارات الأساسية والمعرفة

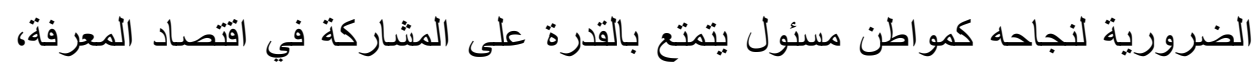
ولكي يتحقق ذلك الهدف ، يجب على معاهد إعداد أعضاء هيئة التدريس ومعاونيهم

وكذلك المر اكز المخصصة لتنمية قدر اتهم أن : (NCATE , 2008)

- تتأكد من أن أعضاء هيئة التدريس ومعاونيهم الجدد يلمون بالمحتوى الضروري، و المهارات، و المعرفة التربوية والمهنية المطلوبة للتدريس المستقل و التعاوني . - - تتأكد من أن جميع العاملين بالوظائف الإدارية يلمون بالمهارات والمعرفة التي ولئ تساعدهم على توفير بيئة تساعد الطالب على التعلم . - ت تتبني أثنكال متنوعة من القياس تخضع للمتابعة والتطوير وتستخدم نتائجها في تحديد ما إذا كان أعضاء هيئة التدريس تتوافر لديهم المعايير المهنية للتدريس التي وني تساعد الطلاب على التعلم. - تركز على إعداد أعضاء هيئة التدريس لمجتمع متنوع من الطلاب . - تعد أعضاء هيئة التدريس الذين تتو افر لديهم القدرة على دمج التكنولوجيا مع التعليم لتعزيز تعلم الطلاب . مله - - تشجع الممارسة الميدانية والتطوير المستمر و والتعاون بين المعلمين و المتعلمين

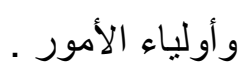

- - تنظر إلى إعداد عضو هيئة التدريس وتطويره على أنه سلسلة تبدأ من الإعداد قبل

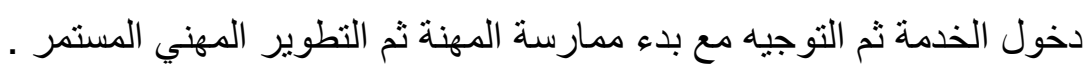
- تتأكد من أن عضو هيئة التدريس بعد إعداده مهنيًا يكون قادرًا على مساعدة جميع الطلاب على التعلم، والتدريس لجميع الطلاب في ضوء معايير الروابط المهنية 


\section{د/ أحمد عبد الفتاح حمدي الهنداوي}

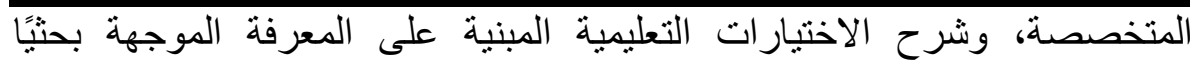
و الممارسة الجيدة، واستخدام طرق فعالة في تدريس الطلاب ذوى الأصول الاجتماعية المختلفة، والاعتماد على الممارسة والتغذية الراجعة، واستخدام التكنولوجيا في التعليم بفعالية، ودراسة الموضوعات التي يتم التخطيط لتدريسها

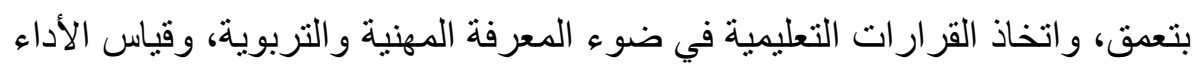
بشكل منو اصل و القدرة على المناقشة. - تتأكد من أنه بعد إعداد المديرين والإخصائيين من غير أعضاء هيئة التدريس مهنيًا تكون لديهم القدرة على تطبيق ما اكتسبوه من معرفة ومهار ات مهنية في بيئة تساعد

$$
\text { على تعلم جميع الطلاب. }
$$

ومن خلال ما سبق يتضح أن هناك العديد من الممارسات التي ثبت نجاحها في عدة جهات و لا شك أنها ساهت بشكل كبير في تميز برامج إعداد المعلمين بها، وهذا ليس مبنيَّا على وجهات نظر مهنية وإنما إثبات علمي من خلال مؤشرات أداء تم قياسها قبل وأثناء وبعد تبنيها لممارسة معينة، ومع الوقت ومع تكرار التجربة يمكن أن تسهم هذه الممارسات في الحفاظ على الجودة وكداعم للمعايير التشريعية الإلزامية، والتقييم الذاتي، تحليل السياسات ـ من خلال تحليل السلوك الواضح و الملموس لمعلم القرن الحادي والعشرين - بالإضافة إلى تحليل القضايا المتعلقة بأولويات التطوير و التحسين، بالإضافة إلي تحقيق الاستفادة المنلى من الفرص الضائعة وبتكلفة منخفضة وقليل من المخاطر، كما يركز هذا النهج لأفضل الممارسات على تعزيز التعلم المستمر لدى المعلم، والسعي نحو إيجاد لغة مشتركة وموحدة بين جميع القائمين داخل المؤسسات وخارجها، بالإضافة إلي المساهمة في تطوير السياسة التعليمية بالاستناد إلى الممارسات القابلة للتحقيق. 
إدارة أولويات برنامج الابلوم العام في التربية بجامعة الأزهر في ضوء ملخل المقارنة المرجعية benchmarking

رابعاً: استطلاع آراء الخبراء حول التصور المناسب لإدارة أولويات البرنامج في ضوء المقارنة المرجعية

استهدف هذا الجزء من البحث؛ استطلاع آراء عينة عمدية (قصدية) من الخبر اء وثيقي الصلة ببرنامج الدبلوم العام في التربية بجامعة الأز هر، و الذين تم انتقاؤهم من الفئات الآتية: (أعضاء فريق إعداد الخطة الاستر اتيجية ـ إدارة البرنامج - رؤساء

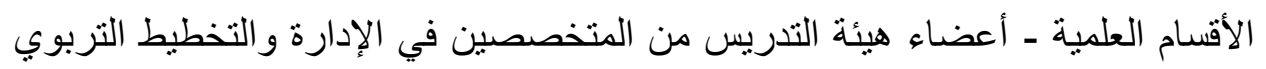

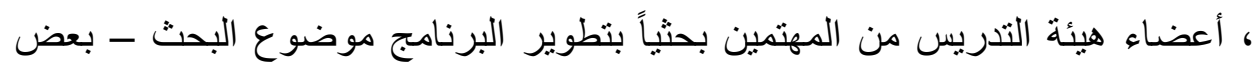
المشاركين في تنفيذ فعاليات إدارة البرنامج في فترات سابقة) من العاملين بكلية التربية بنين بالقاهرة جامعة الأزهر، حول بناء تصور مستقبلي مناسب لإدارة أولويات برنامج

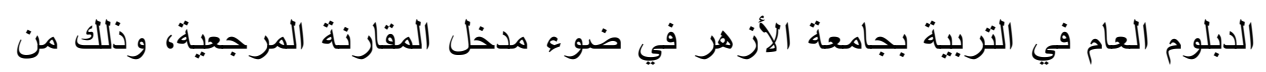

خلال تطبيق أسـوب دلفي Delphi Technique. وتقوم فكرة أسـوب دلفي - كأحد أساليب الدراسات المستقبلية ـ على أخذ

تصـورات عدد من الخبراء في تخصصات مختلفة ممن لهم علاقة بالتغيرات التي

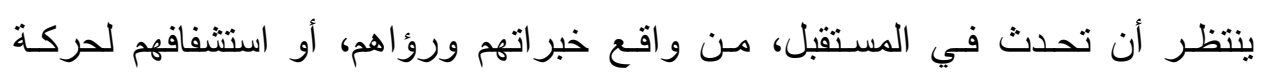

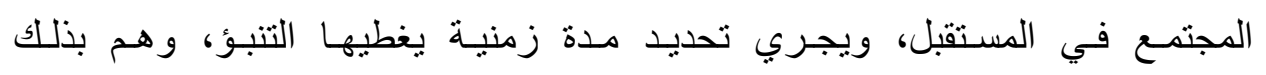
يسـاهمون في إجر اء تعديـلات مستقبلية أو المشاركة في معالجة الأخطساء، وتتمثل أهم

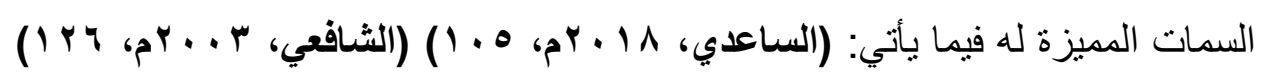

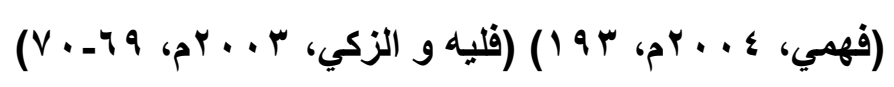

- - أسلوب علمي لتنظيم الاتصالات بين مجموعة من الخبراء، بما بسمح لهم من التعامل ككل دون الجلوس وهم مجتمعين، حول مشكلة أو قضية ما ير اد جمع الآر اء حولها أو 
د/ أحمد عبد الفتاح حمدي الهنداوي

تصورات مستقلية بشأنها، للتوصل إلي مجموعة من الإجراءات المنرابطة

و المتتابعة، والتقريب بين وجهات النظر ، و الوصول بها إلى صيغة متفق عليها.

- أداة مسحية لعقد مناقنـات بين الخبراء ، وتقدَّم من خلال جولات عديدة مع مجموعة منتقاة من الخبر اء بهدف التوصل إلى درجة من الاتفاق العام بين الخبراء فيما يتعلق بتحديد اتجاهات معينة واحتمالية حدوثها وزمن حدوثها وتأثثرها المتوقع، فهو أسلوب لبناء الاتصال بين مجموعة من الأفر اد المتخصصين أو الخبر اء بغرض حل مشكلة معقدة أو مناقثة موضوع منشابك بأسلوب جماعي.

- - يساعد هذا الأسلوب في الحصول على أكبر قدر مدكن من الآراء والمعلومات حول موضوع ما من الخبراء والمتخصصين لاستخدامها في تحسين المجال المراد تطويره؛ حيث إن الفكرة الأساسية تكمن في اثتراك مجموعة من الخبراء في التفكير حول مشكلة ما، أو دراسة مشكلة تتعلق بالحاضر أو المستقبل للوصول إلى قرار معين بشأنها أو اقتراح حلول مناسبة لها، وإن نتائج تفكير الجماعة أفضل كثيرًا من نتائج تفكير فرد و احد في تللك الجماعة. - - يتميز أسلوب دلفاي عن غيره من الأساليب المستخدمة في الدراسات المستقبلية؛ بأن حجم المعلومات المتاحة لمجموعة من الخبر اء أكبر من حجم المعلومات المتاحة لأى فرد فيها، مهما كان هذا الفرد على علم كبير في ميدان التخصص، وأن مجموعة الخبراء غالباً ما تكون لهم رؤاهم الخاصة لأبعاد القضية المستقبلية وطريقة حلها، نظراً لاختلاف تخصصاتهم ومدارسهم الفكرية، وهذا يزيد من احتمالية الرؤية الثاملة لأبعاد القضية مما يزيد من احتمالات شمولية الحلول لمختلف جوانبها، و العوامل المؤثرة فيها، كما أن المجموعة عادة ما تكون أكثر قدرة على مواجهة المخاطر و التحديات، وأن الحلول التي تتخذها المجوعات تكون عادة أكثر جرأة من 
إدارة أولويات برنامج الدبلوم العام في التربية بجامعة الأزهر في ضوء مدخل المقارنة المرجعية benchmarking

الحلول التي يتخذها الأفر اد، وذلك من منطلق التدعيم والمؤازرة التي يقدمها الخبراء بعضهم لبعض.

- - ينبغي على المستخدم لأسلوب دلفاب أن ير اعي بعض الضمانات حتى يخرج بنتائج

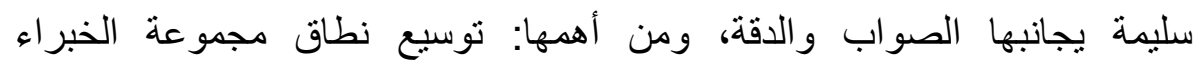
والمختصين المشاركين بالرأي في استبانات دلفاي بحيث لا يكونون من مدرسة

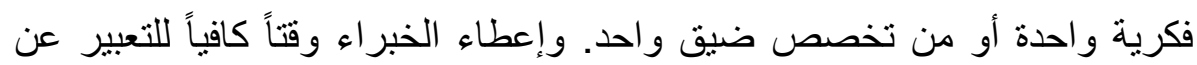
آرائهم، و عدم استعجالهم بطريقة قد تؤدى إلى إهمال الخبير الإجابة على الاستبانات

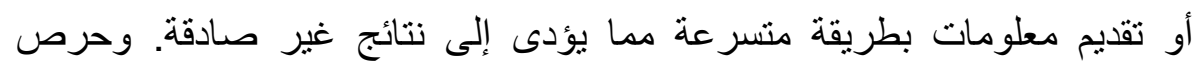
الباحث المستخدم لأسلوب دلفاب على الدقة والموضوعية وبعده عن التحيز لآراء بعض الخبر اء، أو إهماله لآراء البعض الآخر مهما كانت غريبة.

- وينم تطبيق أسلوب دلفابي بجولاته من خلال تحديد مجموعة الخبراء الذين لديهم خبرة بهذا المجال، ثم إعداد استمارة مفتوحة من خلال الإطار النظري للار اسة

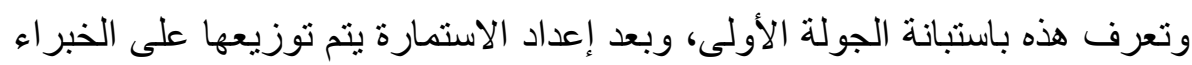

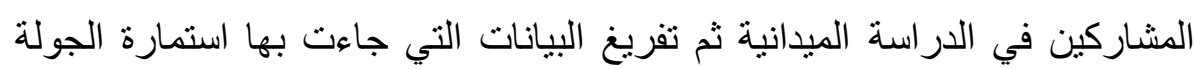
الأولى وترتيب ما توصل إليه الباحث في هذه الجولة وإعداد استمارة الجولة الثانية وهى شبه مغلقة، ثم يقوم الباحث بتفريغ البيانات التي طرحت في استمارة الجولة لهابه

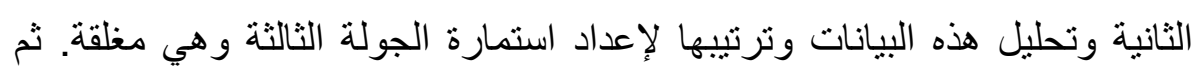
يقوم الباحث بتفريغ البيانات التي طرحت في استمارة الجولة الثالثة وتحليلها وترتيبها, و التوصل إلى نتائج الدر اسة ميدانيا.

ومن خلال ما سبق يتضح أن أسلوب دلفي يتم في صورة مناقثنة غير مباثرة بين مجموعة من الخبر اء والمتخصصين في مجالات مختلفة ذات صلة بموضوع البحث 


\section{د/ أحمد عبد الفتاح حمدي الهنداوي}

- من و اقع خبر اتهم و انتماءاتهم الفكرية - ودون معرفة شخصية بينهم، و إنما معرفة آرائهم وخبراتهم فقط في أكثر من جولة للوصول للنتيجة التي يسعى إليها البحث. وفي ضوء أهداف الدراسة الحالية والمتمثلة في تقديم تصور مستقبلي مناسب لإدارة أولويات برنامج الدبلوم العام في التربية بجامعة الأزهر في ضوء مدخل المقارنة المرجعية؛ كان من المناسب لطبيعة الدراسة والهدف منها، أن يتم وضع هذا التصور من خلال الرجوع إلى آراء مجموعة من الخبراء المتخصصين والذين لهم صلة بموضوع الدراسة للاسترشاد بآر ائهم وخبر اتهم في هذا المجال، ويمكن توضيح فئات العينة وأعدادهم من بن بون

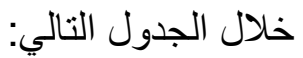

\section{جدول (7) يوضح فئات العينة وأعدادهم}

\begin{tabular}{|c|c|c|c|c|}
\hline الفاقد & استردادهارات تما & تم تسليمهار & الفئــة & ? \\
\hline - & 0 & 0 & أساتذة الإدارة و التخطيط التربوي & 1 \\
\hline - & $r$ & r & أعضاء فريق إعداد الخطة & $r$ \\
\hline$r$ & 1 & $r$ & إدارة كلية التربية بنين بالقاهرة & $r$ \\
\hline$r$ & $r$ & $\varepsilon$ & رؤساء الأقسام العلمية & $\varepsilon$ \\
\hline$r$ & 7 & 9 & مديري مر اكز التأهيل التربوي & 0 \\
\hline - & $r$ & $r$ & المهتمين بحثياً بتطوير البرنامج & 7 \\
\hline - & $r$ & $r$ & إدارة البرنامج في فترات سابقة & V \\
\hline V & r) & rA & ال الإجمالي & \\
\hline
\end{tabular}

من خلال الجدول السابق يتضح أن عدد (V) من الخبراء الذين تم تحديدهم لم بيتجيبوا بإبداء رأيهر حول بنود الاستمارة، حيث اعتذروا عن التطبيق نظراً لما تمثله بنود الاستمارة من عبء حيث أسئلتها المفتوحة التي تحتاج إلى مزيد من الوقت و الجهد. وقد نم تطبيق أسلوب دلفابي في الدر اسة الحالية من خلال ثلاث جو لات متتابعة ومتتالية، كانت كل جولة بمثابة تغذية راجعة للجولة السابقة لها، وذلك علي النحو الآتي:

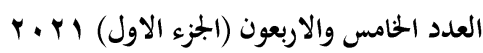

(75)
مجلة كلية التربية- جامعة عين شثس 
إدارة أولويات برنامج الابلوم العام في التربية بجامعة الأزهر في ضوء ملخل المقارنة المرجعية benchmarking

- - تم إعداد استمارة الجولة الأولى استناداً إلى الإطار النظري للبحث ونتائج الدراسات السابقة، وتضمنت الاستمارة في بدايتها توضيحاً بالهدف منها ومحتو اها، وأنها تمثل لإنل جزءاً من بحث بعنوان (إدارة أولويات برنامج الدبلوم العام في التربية بجامعة الأزهر في ضوء مدخل المقارنة المرجعية ـ دراسة مستقلية)، وتم إيضاح أهمية وسرية آرائهم وأنها تستخدم لأغراض البحث العلمي، وتعرف بعض البيانات

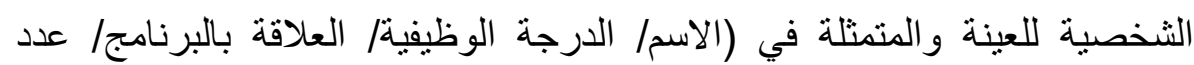
سنوات الخبرة/ البريد الإلكتروني) لسهولة التواصل في الجولات التالية. - - تم توجيه بعض الأسئلة المفتوحة لأفراد عينة الدراسة من الخبر اء، متضمنة العديد

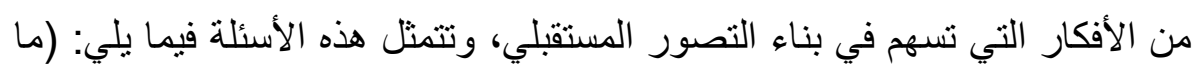
المجالات/ القضايا ذات الأولوية والتي تشكل إطار اً لتطوير برنامج الدبلوم العام في التربية بجامعة الأزهر؟ وما أهم الصعوبات التي تشكل عائقاً أمام إدارة أولويات

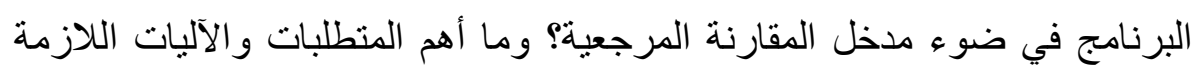

لإدارة أولويات البرنامج في ضوء مده مدل المقارنة المرجعية؟

- - بعد تجميع استمارات الجولة الأولى البالغ عددها (Y) استمارة، تم تفريغها وتصنيفها , من خلال نظام الحزم والتكرارات، و التوفيق بين الاستجابات المتشابهة

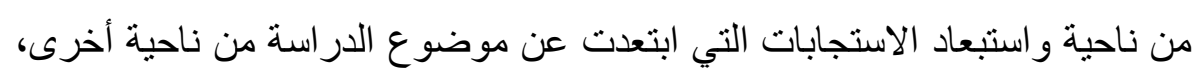

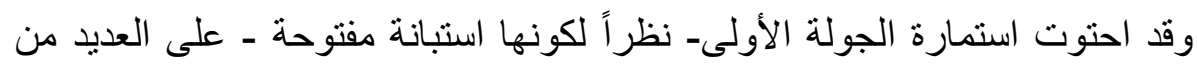

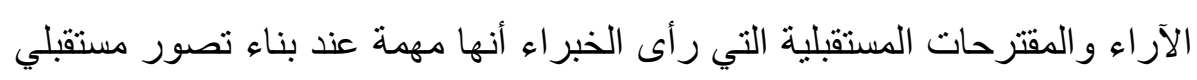
لإدارة أولويات برنامج الدبلوم العام في التربية بجامعة الأزهر في ضوء ضوه مدخل

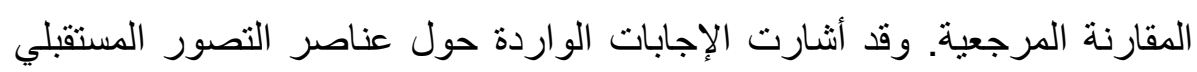
إلى العديد من الأفكار والآر اء المهمة التي لم يصل أي منها إلى حد الإجماع.

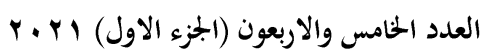

(76)

مجلة كلية التربية- جامعة عين شثس 
- - في الجولة الثانية؛ تم استفتاء الخبر اء مرة أخرى حول ما طرحوه في الجولة الأولى للوصول إلى اتفاق في الرأي حول محاور الاستبانة، فبعد تحليل إجابات الجولة الأولى وتصنيف الاستجابات التي تم الحصول عليها، تم تصميم استبانة شبه مغلقة من خلال صياغة أسئلة ذات مقياس من ثلاث درجات للمو افقة (كبيرة - متوسطة ـ ضعيفة)، يجيب أفر اد العينة عليها بوضع علامة (صح) أمام الاستجابة التي تتفق مع آرائهم، وأسئلة مفتوحة في نهاية كل محور من محاور الاستبانة تركت فيها الحرية لأفراد العينة، وبعد أن تم تجميع عناصر ومحاور الاستبانة، تم تحكيمها، وإدخال بعض التعديلات عليها, من أجل وضوح مفرداتها، وكذلك تعليماتها، واستبعاد المفردات التي لا تؤدى إلى بيانات مفيدة. وتم حساب تكرار الاستجابات عن كل سؤال ونسبتها المئوية، و المتوسط الحسابي، لتحديد مستوى المو افقة على كل عبارة من عبار ات الاستمارة، وتم حساب المتوسط الحسابي عن طريق إعطاء درجة لكل استجابة من الاستجابات الثلاثة، وفقاً لطريقة ليكرت، فالاستجابة (كبيرة) تعطى الدرجة (r)، والاستجابة (متوسطة) تعطى الدرجة (Y)، والاستجابة (ضعيفة)

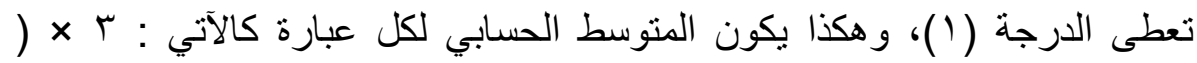

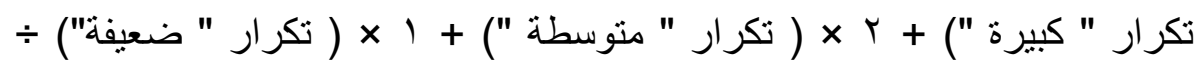

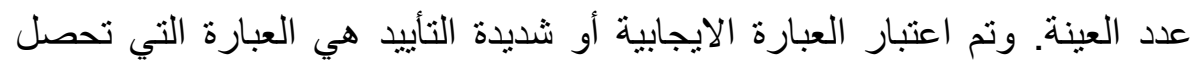
على تمركز لمتوسط الاستجابة ( •^٪ عأكثر ). - استهدفت الجولة الثالثة من جولات دلفاي؛ التوصل إلي الاتفاق بين أفراد العينة من السادة الخبراء وخاصة فيما يتعلق بالعبار ات التي لم تصل إلي نسبة مو افقة (ـ^٪)

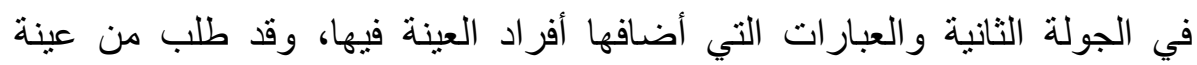
الدراسة تحديد درجة الموافقة من خلال مقياس مكون من ثلاث اختبارات وهى

$$
\text { (كبيرة - منوسطة - ضعيفة). }
$$

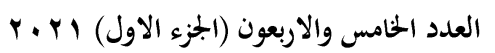

(77)
مجلة كلية التربية- جامعة عين شثس 
إدارة أولويات برنامج الابلوم العام في التربية بجامعة الأزهر في ضوء ملخل المقارنة المرجعية benchmarking

\section{المحور الأول: المجالات/ القضايا التي تُشكل إطاراً لإدارة أولويات البرنامج}

جاءت استجابات أفراد عينة الدراسة من الخبراء في الجولة الأولى حول مجالات/ قضايا إدارة أولويات برنامج الدبلوم العام في التربية بجامعة الأزهر، متضمنة

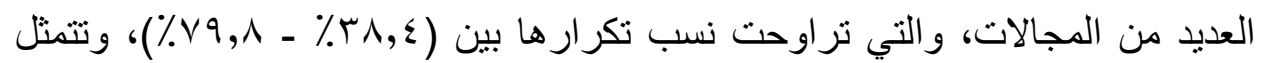
هذه المجالات فيما يلي: (تطوير أنشطة التربية العملية وإجر اءاتها في إحداث التكامل بين الجو انب النظرية والنطبيقية للبرنامج، و إجر اء شر اكات تربوية مع المعاهد الأزهرية والمدارس القريبة من مراكز التأهيل التربوي، وتوظيف تكنولوجيا المعلومات والاتصالات في الجوانب الإدارية والأكاديمية للبرنامج، وتحسين أداء المشاركين في ولي البرنامج وفقاً لاحتياجاتهم المهنية، وإرساء نظام واضح ومحدد للمحاسبية في ضوء والإدائج و إنجازات البرنامج، وتنفيذ برامج إرشادية وتوعوية وتحفيزية للطلاب حول مقومات الريادة العلمية، ووضوح البناء التنظيمي والسياسات الإدارية واللوائح الموجهة للعمل ولم

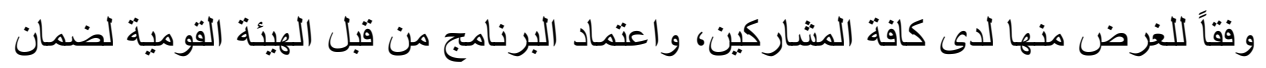
جودة التعليم والاعتماد، والإعداد والتجهيز للمشاركة في جوائز التميز الحكومية، وتطوير نُظُم تقويم الطلاب) وذلك علي اعتبار أن هذه المجالات تحتاج إلى بذل مزيد من ون

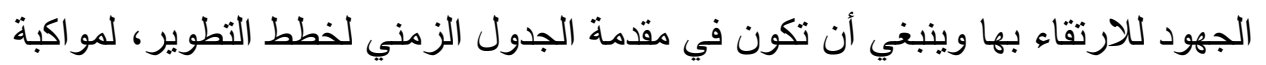
التطور ات في المؤسسات المُناظرة.

وجاءت استجاباتهم في الجولة الثانية حول ما طرحوه من مجالات/ قضايا ـ في

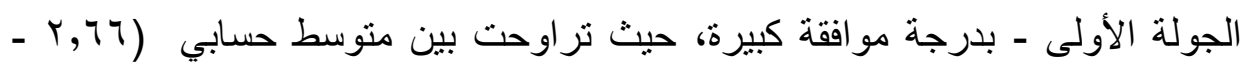

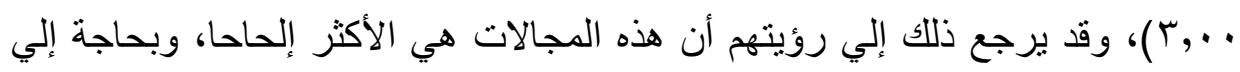
تحسين مستمر، لمواكبة التطورات والتغيرات المحلية والعالمية. كما حصلت هذه رهات المجالات علي نسبة موافقة أعلي من (•^٪) باستثناء المجال "تطوير نُظُم تقويم الطلاب" حيث أفاد البعض بأنه ينبغي إعادة النظر في عمليات تقويم الطلاب كأداة 
د/ أحمد عبد القتاح حمدي الهنداوي

للتطوير والتحسين، حيث إنها تركز بشكل كبير علي الجوانب النظرية مع بعض الخلل في قياس الجوانب العملية، الأمر الذي أدي إلي إعادة صياغتها لأخذ آراء عينة الدراسة من الخبر اء عليها في الجولة الثالثة. كما أظهرت الاستجابات إضافة بعض المجالات المتمثلة في (اتباع سياسة تسويقية توضح من خلالها إمكانات ونتائج البرنامج مقارنة بالبر امج المناظرة) و (إعداد قيادات الصف الثاني وجاهزيتهم للمشاركة في تتفيذ برامج الإصلاح ذات الأولوية)، مما أدى لطرحها علي أفراد العينة في الجولة الثالثة.

وجاءت استجاباتهم في الجولة الثالثة حول ما تم التوصل إلبه في الجولة الثانية من مجالات/ قضنايا تُشكل إطار آ لإدارة أولويات برنامج الدبلوم العام في التربية بجامعة الأزهر، كما هو موضح بالجدول التالي:

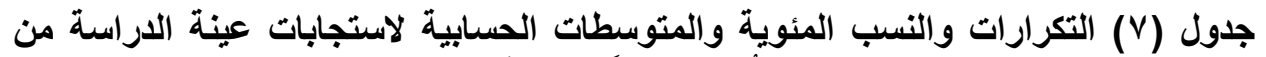

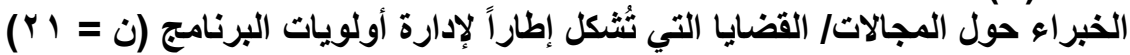

\begin{tabular}{|c|c|c|c|c|c|c|c|c|c|c|c|}
\hline \multirow{3}{*}{ الترتيب } & \multirow{3}{*}{ مستوى المو افقة } & \multirow{3}{*}{ نسبة المو افقة } & \multirow{3}{*}{ منابي } & \multicolumn{6}{|c|}{ درجة الموافقة } & \multirow{3}{*}{ |لالعبـــــارة } & \\
\hline & & & & \multicolumn{2}{|c|}{ ضعيفة } & \multicolumn{2}{|c|}{ متوسطة } & \multicolumn{2}{|c|}{ كبيرة } & & \\
\hline & & & & $\%$ & ك5 & $\%$ & ك & $\%$ & ك5 & & \\
\hline$r$ & كبيرة & $90, r$ & $r, 90$ & - & & $\varepsilon, \wedge$ & 1 & $90, r$ & $r$. & 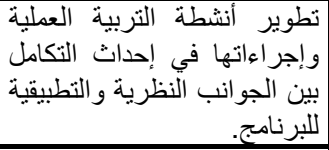 & \\
\hline v & كبيرة & $10, \mathrm{~V}$ & r,人 & - & & $1 \leqslant, r$ & r & $\Lambda 0, \mathrm{v}$ & 11 & 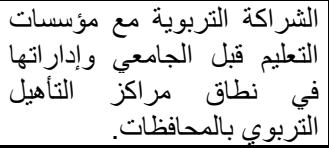 & $r$ \\
\hline r & كبيرة & $90, r$ & $r, 90$ & - & & $\varepsilon, \wedge$ & 1 & $90, Y$ & $r$. & 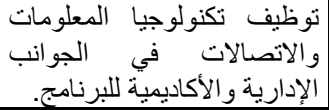 & $r$ \\
\hline 1 & كبيرة & $1 \cdots$ & $r, \ldots$ & - & & - & - & $\cdots$ & Y) & 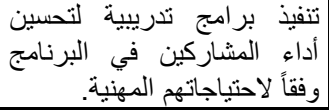 & $\varepsilon$ \\
\hline 7 & كبيرة & $9 \cdot, 0$ & $r, q$. & - & & 9,0 & r & $9 \cdot, 0$ & 19 & 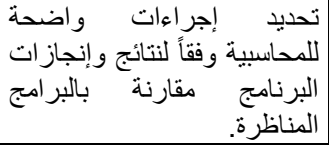 & 0 \\
\hline v & كبيرة & $10, \mathrm{~V}$ & $r, \wedge \tau$ & - & & $1 \leq, r$ & $r$ & $\Lambda_{0}, \mathrm{~V}$ & 11 & 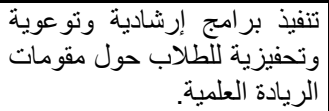 & 7 \\
\hline
\end{tabular}

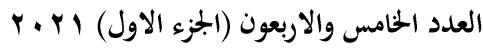

(79)

مجلة كلية التربية- جامعة عين شمس 
إدارة أولويات برنامج الدبلوم العام في التربية بجامعة الأزهر في ضوء مدخل المقارنة المرجعية benchmarking

\begin{tabular}{|c|c|c|c|c|c|c|c|c|c|c|c|}
\hline \multirow{3}{*}{ الترتيب } & \multirow{3}{*}{ 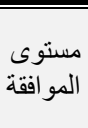 } & \multirow{3}{*}{ المبلة } & \multirow{3}{*}{ | متوسط } & \multicolumn{6}{|c|}{ درجة الموافقة } & \multirow{3}{*}{ العبـــــارة } & \\
\hline & & & & \multicolumn{2}{|c|}{ ضعيفة } & \multicolumn{2}{|c|}{ متوسطة } & \multicolumn{2}{|c|}{ كبيرة } & & \\
\hline & & & & $\%$ & ك) & $\%$ & 5) & $\%$ & 5 & & \\
\hline 1 & كبيرة & $1 \ldots$ & $r, .$. & & - & - & - & $1 .$. & r) & 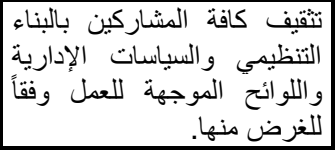 & v \\
\hline 1. & كبيرة & $10, \mathrm{~V}$ & $r, \wedge 1$ & $\varepsilon, \Lambda$ & 1 & 9,0 & $r$ & $10, \mathrm{v}$ & 11 & 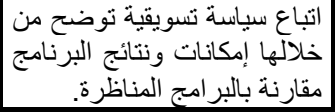 & $\wedge$ \\
\hline 1. & كبيرة & $10, \mathrm{~V}$ & $r, \wedge 1$ & $\varepsilon, \Lambda$ & 1 & 9,0 & $r$ & $10, \mathrm{v}$ & 11 & 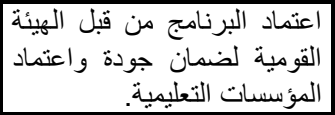 & 9 \\
\hline 1. & كبيرة & $10, \mathrm{~V}$ & $r, \wedge 1$ & $\varepsilon, \wedge$ & 1 & 9,0 & $r$ & $10, \mathrm{v}$ & 11 & 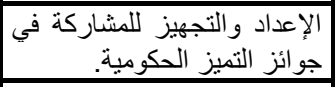 & 1. \\
\hline$r$ & كبيرة & $90, r$ & $r, 90$ & & & $\varepsilon, \lambda$ & 1 & $90, r$ & $r$. & إلتعلادة النظر فئي عمليات تقويم للتطوير & 11 \\
\hline V & كبيرة & $10, \mathrm{~V}$ & $r, \wedge \uparrow$ & & & $1 \leqslant, \Gamma$ & $r$ & $\Lambda_{0}, \mathrm{v}$ & 11 & 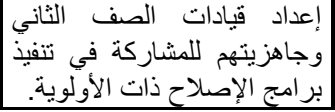 & $M$ \\
\hline
\end{tabular}

من خلال الجدول السابق يتضح أن استجابات أفراد عينة الدراسة من الخبراء

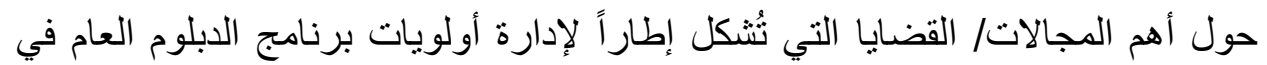
التربية بجامعة الأزهر؛ جاءت بدرجة موافقة كبيرة، وتراوحت بين متوسط حسابي

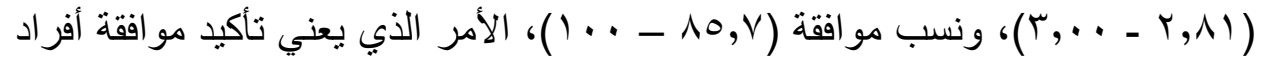
عينة الدر اسة علي تلك المجالات، والتي جاءت مرتبة علي النحو التالي: 1 ـ تثقيف كافة المشاركين بالبناء التنظيمي والسياسات الإدارية واللوائح الموجهة للعمل وفقاً للغرض منها، و تنفيذ بر امج تدريبية لتحسين أداء المشاركين في البرنامج وفقاً

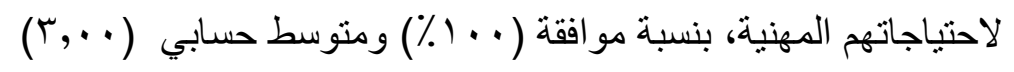

rـ تطوير أنشطة التربية العملية وإجراءاتها في إحداث التكامل بين الجوانب النظرية و التطبيقية للبرنامج، و توظيف تكنولوجيا المعلومات والاتصالات في الجوانب 
د/ أحمد عبد الفتاح حمدي الهنداوي

الإدارية و الأكاديمية للبرنامج، و إعادة النظر في عمليات تقويم الطلاب كأداة

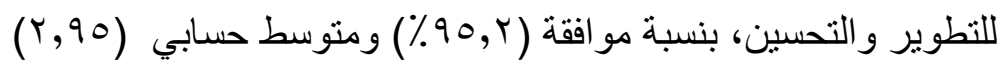
r- تحديد إجراءات واضحة للححاسبية وفقاً لنتائج و إنجاز ات البرنامج مقارنة بالبرامج

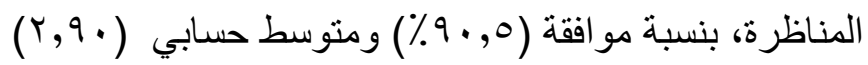
عـ الثر اكة التربوية مع مؤسسات التعليم قبل الجامعي وإداراتها في نطاق مراكز التأهيل التربوي بالمحافظات، و تنفيذ برامج إرشادية وتوعوية وتحفيزية للطلاب

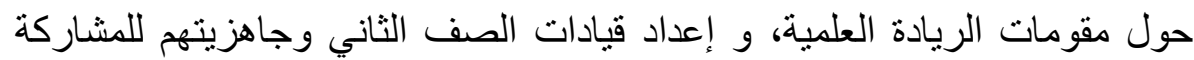

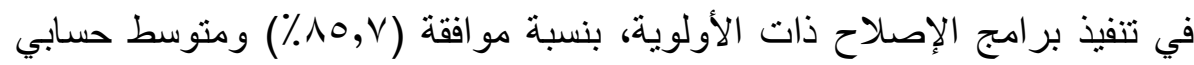
$(r, \wedge \uparrow)$

○ـ اعتماد البرنامج من قبل الهيئة القومية لضمان جودة و اعتماد المؤسسات التعليمية، و اتباع سياسة تسويقية توضح من خلالها إمكانات ونتائج البرنامج مقارنة بالبرامج المناظرة، و الإعداد والتجهيز للمشاركة في جوائز التميز الحكومية، بنسبة موافقة

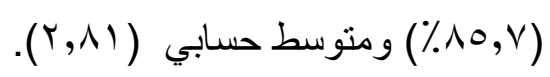

المحور الثاني: الصعوبات التي يمكن أن تشكل عائقاً أمام إدارة أولويات البرنامج جاءت استجابات أفراد عينة الدراسة من الخبراء في الجولة الأولى حول أهم الصعوبات التي يمكن أن نتكل عائقاً أمام إدارة أولويات برنامج الدبلوم العام في التربية

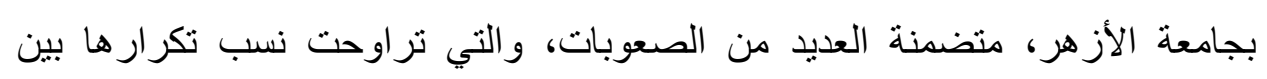

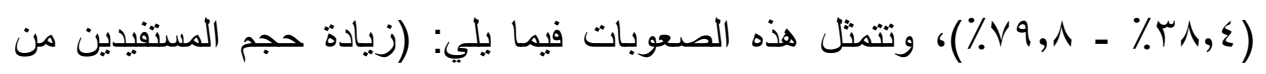
خدمات برامج الإصلاح ذات الأولوية حيال تنفيذها، وطول الفترة الزمنية اللازمة لتنفيذ بر امج الإصلاح ذات الأولوية، و المبالغة في الروتين والإجراءات الإدارية اللازمة حيال

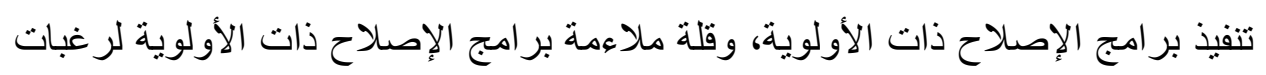

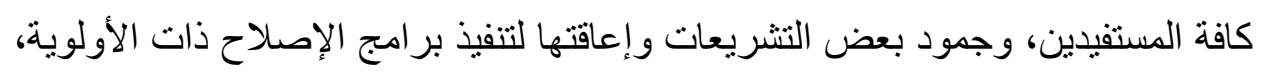

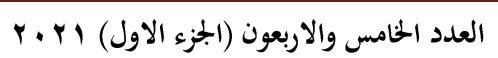

(81)
مجلة كلية التربية- جامعة عين شمس 
إدارة أولويات برنامج الابلوم العام في التربية بجامعة الأزهر في ضوء ملخل المقارنة المرجعية benchmarking

وقلة توافر مصادر التمويل اللازمة للإنفاق علي برامج الإصلاح ذات الأولوية، وقلة

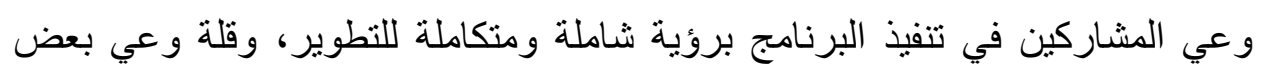

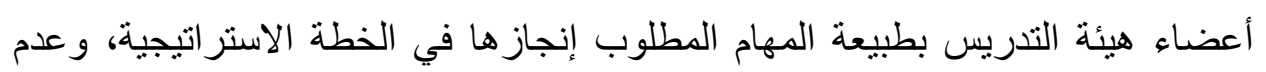

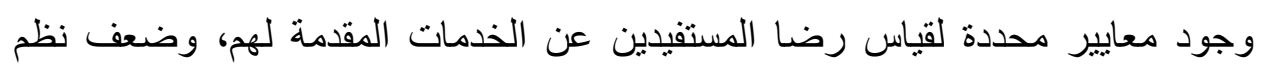
المعلومات التي يمكن الاعتماد عليها في تتفيذ الخطة الاستراتيجية للكلية.) وذللك علي اعتبار أن هذه الصعوبات قد تشكل عائقاً أمام إدارة أولويات البرنامج.

وجاءت استجاباتهم في الجولة الثانية حول ما طرحوه من صعوبات - في

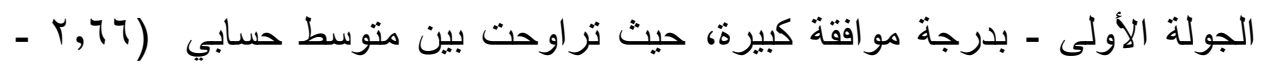

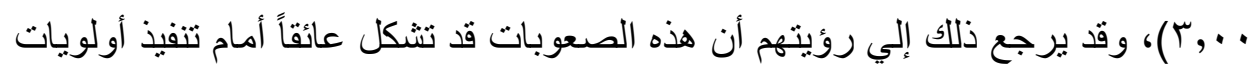

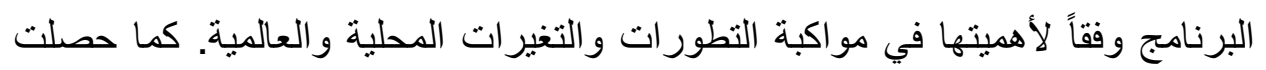
هذه الصعوبات علي نسبة موافقة أعلي من (•^٪). كما أظهرت الاستجابات إضافة بعض الصعوبات المتمثلة في (قلة الاهتمام بتدريب العاملين علي تنفيذ الخطة الاستر اتيجية، وقلة حو افز أعضاء هيئة التدريس مقارنة بما هو مطلوب منهم، والافتقار الي ثقافة تنظيمية نشجع على تتفيذ الخطة الاستراتيجية، وكثرة الأعباء الفنية والإدارية الملقاة على عاتق أعضاء هيئة التدريس بالكلية، وزيادة حدة الصر اعات بين العاملين في لئه الكلية)، مما أدى لطرحها علي السادة الخبر اء في الجولة الثالثة.

وجاءت استجاباتهم في الجولة الثالثة حول ما تم التوصل إليه في الجولة الثانية

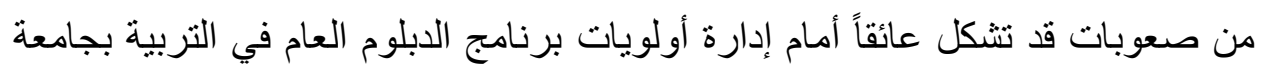
الأزهر ، كما هو موضح بالجدول التالي:

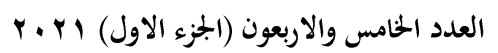

(82)
مجلة كلية التربية- جامعة عين شثس 
د/ أحمد عبد الفتاح حمدي الهنداوي

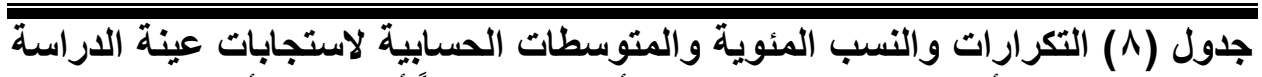

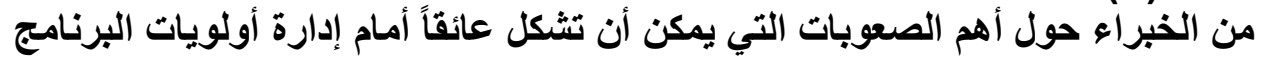

( $r \mid=0$ )

\begin{tabular}{|c|c|c|c|c|c|c|c|c|c|c|c|}
\hline \multirow{3}{*}{ الترتيب } & \multirow{3}{*}{ المو افقة } & \multirow{3}{*}{$\begin{array}{r}\text { نسبة } \\
\text { المو افق }\end{array}$} & \multirow{3}{*}{ مستيط } & \multicolumn{6}{|c|}{ درجة الموافقة } & \multirow{3}{*}{ العبــــــارة } & \\
\hline & & & & \multicolumn{2}{|c|}{ ضعيفة } & \multicolumn{2}{|c|}{ متوسطة } & \multicolumn{2}{|c|}{ كبيرة } & & \\
\hline & & & & $\%$ & 5) & $\%$ & 5 & $\%$ & 5 & & \\
\hline $1 \pi$ & كبيرة & $\Lambda_{0}, \mathrm{~V}$ & $r, \wedge)$ & $\varepsilon, \wedge$ & 1 & 9,0 & r & $\wedge 0, \mathrm{v}$ & 11 & 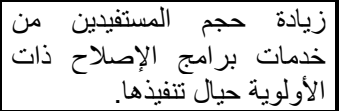 & \\
\hline $1 \pi$ & كبيرة & $\Lambda_{0}, \mathrm{v}$ & $r, \Lambda)$ & $\varepsilon, \wedge$ & 1 & 9,0 & r & $10, \mathrm{v}$ & 11 & 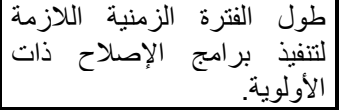 & r \\
\hline 0 & كبيرة & $90, Y$ & $r, 90$ & - & & $\varepsilon, \wedge$ & 1 & $90, r$ & $r$. & 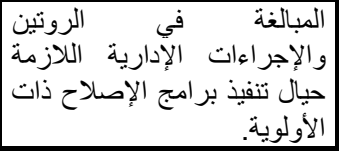 & r \\
\hline $1 \pi$ & كبيرة & $\wedge_{0}, \mathrm{~V}$ & $r, \wedge)$ & $\varepsilon, \wedge$ & 1 & 9,0 & r & $10, \mathrm{v}$ & 11 & الألة ملاءمة بر امج الإصلاح ذاتة & $\varepsilon$ \\
\hline 1. & كبيرة & $9 \cdot, 0$ & $r, q$. & - & & 9,0 & r & $9 \cdot, 0$ & 19 & 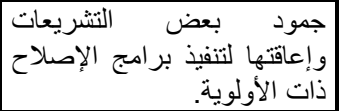 & ० \\
\hline 0 & كبيرة & $90, Y$ & $r, 90$ & - & - & $\varepsilon, \wedge$ & 1 & $90, r$ & $r$. & 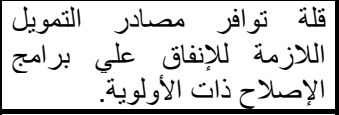 & 7 \\
\hline 1 & كبيرة & $1 \cdots$ & $r, \ldots$ & - & & - & - & $1 \cdots$ & YI & 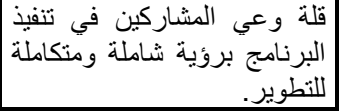 & V \\
\hline 1 & كبيرة & $1 \cdots$ & $r, \ldots$ & - & & - & - & $1 \cdots$ & YI & 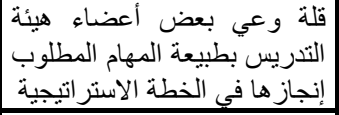 & $\wedge$ \\
\hline 0 & كبيرة & $90, r$ & $r, 90$ & - & & $\varepsilon, \lambda$ & 1 & $90, r$ & $r$. & 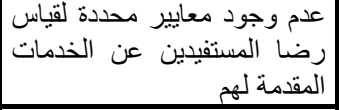 & 9 \\
\hline 1. & كبيرة & $9 \cdot, 0$ & $r, q \cdot$ & - & & 9,0 & r & $9 \cdot, 0$ & 19 & 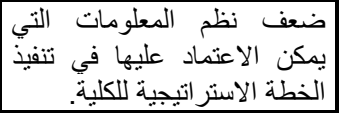 & 1. \\
\hline 0 & كبيرة & $90, Y$ & $r, 90$ & & & $\varepsilon, \lambda$ & 1 & $90, Y$ & $r$. & علي تلفيذ الخطمة الاستر اتبجية. & 11 \\
\hline 1 & كبيرة & $1 \cdots$ & $r, \ldots$ & & & - & - & $1 \cdots$ & rI & مقارنة بوافز هو مطلوب هيئة التدريس منهر. & IT \\
\hline 1 & كبيرة & $1 \ldots$ & $r, \ldots$ & & & - & - & $1 \ldots$ & rI & 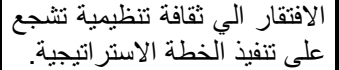 & r \\
\hline
\end{tabular}

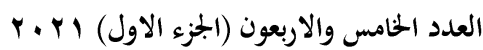

(83)

مجلة كلية التربية- جامعة عين شمس 
إدارة أولويات برنامج الدبلوم العام في التربية بجامعة الأزهر في ضوء مدخل المقارنة المرجعية benchmarking

\begin{tabular}{|c|c|c|c|c|c|c|c|c|c|c|c|}
\hline \multirow{3}{*}{ الترتيب } & \multirow{3}{*}{ المو افقوى } & \multirow{3}{*}{ المبو افق } & \multirow{3}{*}{ متوسط } & \multicolumn{6}{|c|}{ درجة الموافقة } & \multirow{3}{*}{ العبــــــارة } & \\
\hline & & & & \multicolumn{2}{|c|}{ ضعيفة } & \multicolumn{2}{|c|}{ متو سطة } & \multicolumn{2}{|c|}{ كبيرة } & & \\
\hline & & & & $\%$ & s & $\%$ & 5 & $\%$ & S & & \\
\hline 0 & كبيرة & $90, r$ & $r, 90$ & & & $\varepsilon, 1$ & 1 & $90, r$ & $r$. & التثلقة على الأعباء الفنية أعضاء هالإدارية & $1 \varepsilon$ \\
\hline 1. & كبيرة & $9 ., 0$ & $r, q$. & & & 9,0 & r & $9 ., 0$ & 19 & زلعادلين في الكلية. & 10 \\
\hline
\end{tabular}

من خلال الجدول السابق يتضح أن استجابات أفراد عينة الدراسة من الخبراء حول أهم الصعوبات التي يمكن أن ثُشكل عائقاً أمام إدارة أولويات برنامج الدبلوم العام في التربية بجامعة الأزهر؛ جاءت بدرجة مو افقة كبيرة، وتر اوحت بين متوسط حسابي

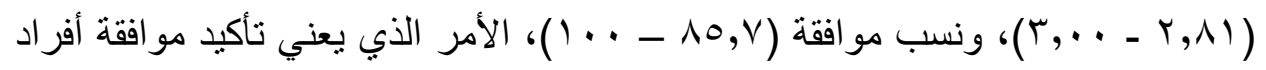
عينة الدراسة علي تلك الصعوبات، والتي جاءت مرتبة علي النحو التالي: 7- قلة حوافز أعضاء هيئة التدريس مقارنة بما هو مطلوب منهم، و الافتقار الي ثقافة تنظيمية تشجع على تتفيذ الخطة الاستراتيجية، و قلة وعي المشاركين في تنفيذ

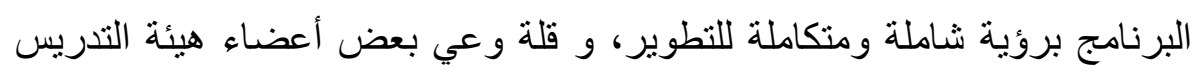
بطبيعة المهام المطلوب إنجاز ها في الخطة الاستراتيجية، بنسبة موافقة ( . (1\%)

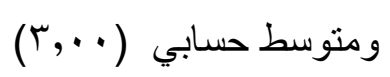

Vـ قلة تو افر مصادر التمويل اللازمة للإنفاق علي برامج الإصلاح ذات الأولوية، و و

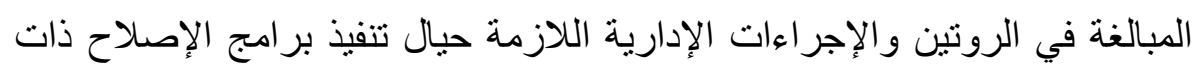

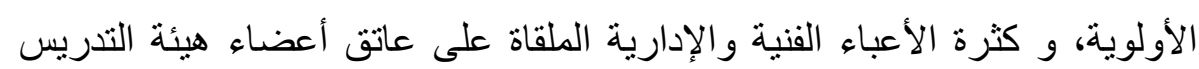

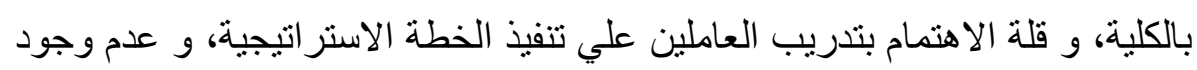
معايير محددة لقياس رضا المستفيدين عن الخدمات المقدمة لهم، بنسبة موافقة

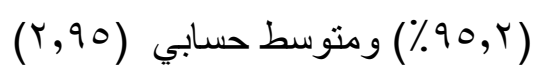

العدد الخامس والاربعون (الجزء الاول) ب r.r

(84)

مجلة كلية التببية- جامعة عين ثمس 


\section{د/ أحمد عبد الفتاح حمدي الهنداوي}

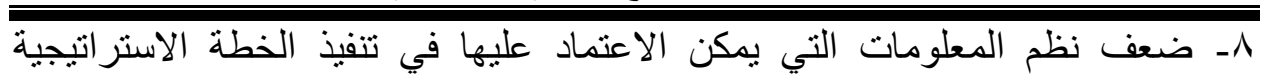
للكلية، و زيادة حدة الصراعات بين العاملين في الكلية، و جمود بعض التشريعات و إعاقتها لتنفيذ برامج الإصلاح ذات الأولوية، و بنسبة مو افقة (0, .9٪\%) ومتوسط

$$
\text { حسابي ( ) ( }
$$

9 - زيادة حجم المستفيدين من خدمات برامج الإصلاح ذات الأولوية حيال تنفيذها، و طول الفترة الزمنية اللازمة لتنفيذ برامج الإصلاح ذات الأولوية، و قلة ملاءمة برامج الإصلاح ذات الأولوية لرغبات كافة المستفيدين، بنسبة موافقة (10,々٪)

$$
\text { ومتوسط حسابي ( }
$$

المحور الثالث: متطلبات إدارة أولويات البرنامج في ضوء مدخل المقارنة المرجعية جاءت استجابات أفراد عينة الدراسة من الخبراء في الجولة الأولى حول أهم المتطلبات اللازمة لإدارة أولويات البرنامج في ضوء مدخل المقارنة المرجعية، متضمنة

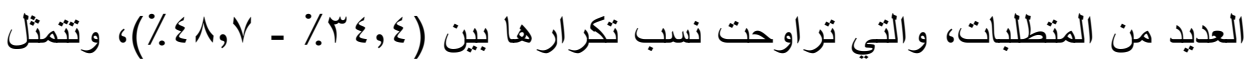

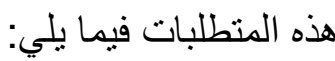

أ- تحديد أهداف إدارة أولويات البرنامج في ضوء المقارنة المرجعية: من حيث (تحديد درجة الأسبقية أو الأفضلية في تتفيذ جهود تطوير برنامج الدبلوم العام في مئي التربية بناء علي أهميتها في مواجهـة المشكلات الملحـة وتحقيق ميزتها التنافسية، وتحقيق التوازن والتنسيق بين الحاجات والمشكلات الأكاديمية وبين الإمكانيات والموارد البشرية والتنظيمية، وتكاتف جهود المشاركين ببرنامج الدبلوم العام في التربية في التعامل بواقعية مع جهود التطوير وتنفيذها ومتابعتها وفقاً لأولوياتها، وتحديد المجالات/ القضايا التي تُشكل إطار ال لإدارة أولويات برنامج الدبلوم العام في التربية والأساليب المستخدمة في ذللك، ورصد أهم العوامل المؤثرة في إدارة أولويات البرنامج والتي تنكل عائقاً أمام تنفيذها، ووضع آليات لسيُّل تجاوزها،

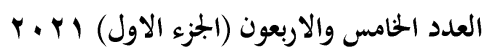

(85)
مجلة كلية التربية- جامعة عين شثس 
إدارة أولويات برنامج الابلوم العام في التربية بجامعة الأزهر في ضوء ملخل المقارنة المرجعية benchmarking

و الحد من الوقت الضائع في الأنشطة و السلوكيات غير المهمة والمهرة للوقت خلال تنفيذ الإدارة لمهامها ومسئولياتها، وتطوير أداء المشاركين ببرنامج الدبلوم العام في ولي التربية وفقاً لظروف المجتمع السائدة والقيود التي قد تواجه تطوير العملية التعليمية

$$
\text { و التعامل معها بموضوعية). }
$$

ب- تحديد أفضل الممارسات موضع المقارنة المرجعة: من حيث (جمع البيانات

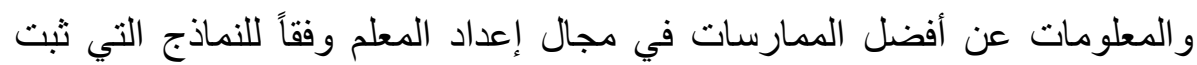
نجاحها، ثم تقييم الممارسات المتميزة في ضوء التوجه الاستراتيجي للكلية ومن وجهة نظر المستفيدين، و انتقاء أفضل الممارسات و أكثرها ملائمة للبرنامج و الوقوف علي نأثير اتها في سياقاتها وبيئتها، مع مر اعاة التأكد من انسجام الممارسات المتميزة مع قيم أعضاء هيئة التدريس ومعتقداتهم و التوفيق بينها، وتبني وتكييف الممارسات المتميزة التي تم انتقاؤها وتوفير الدعم اللازم لتنفيذها).

ج- تحديد المشاركون في إدارة أولويات البرنامج وفقاً لمنهجية المقارنة المرجعية: من حيث مشاركة (أعضاء هيئة التدريس المشاركين في تنفيذ البرنامج، و عينة قصدية من خريجي البرنامج، و موجهين فنيين بالتعليم قبل الجامعي (الأزهري/

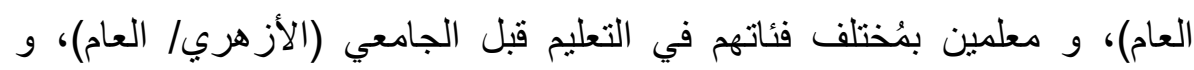
مناصب قيادية بالتعليم قبل الجامعي (الأزهري/ العام)

د- تكامل الجانبين (الاستراتيجي و التشغيلي) في إدارة أولويات البرنامج: من حيث (الاتفاق علي إطار زمني واضح لتنفيذ أولويات البرنامج وفقاً لنتائج المقارنة المرجعية، وإعداد خطة تشغيلية نوضح أدوار كافة المشاركين بالبرنامج ومستويات الأداء المنشودة، و تحديد العلاقات المتداخلة بين (إدارة الدراسات العليا ـ الأقسام 
د/ أحمد عبد الفتاح حمدي الهنداوي

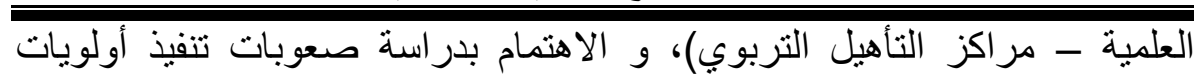

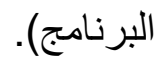

ه- المحاسبية علي نتائج وإنجازات البرنامج: من حيث إجراء (مراجعة دورية لتنفيذ مهام ومسئوليات المشاركين في البرنامج، و التقرير عن ما تم إنجازه و إتاحته لكافة

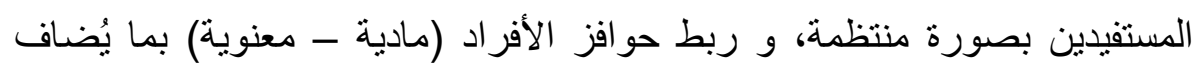

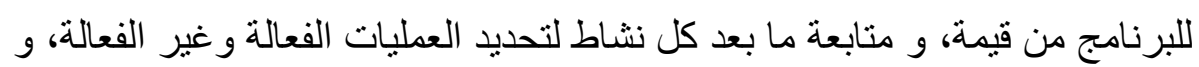
تشجيع الرقابة الذاتية لدى كافة المشاركين في تنفيذ البرنامج).

وجاءت استجاباتهم في الجولة الثانية حول ما طرحوه من منطلبات - في الجولة

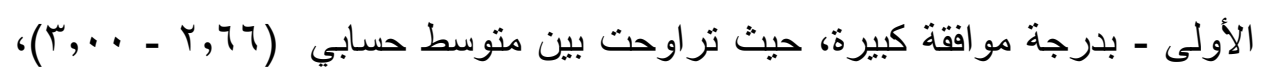
كما حصلت هذه المتطلبات علي نسبة مو افقة أعلي من (،^٪)، باستثناء العبارة "توجيه

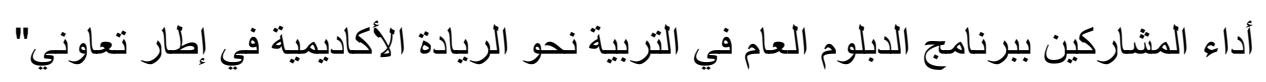
حيث أفاد البعض بأن توجيه أداء المشاركين يكون نحو استثمار الوقت من أجل التميز

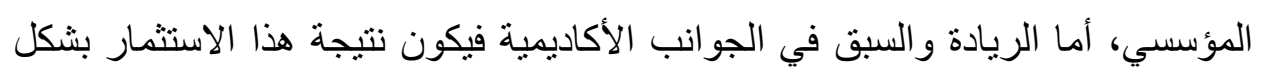
تدريجي، الأمر الذي يتطلب إعادة صياغتها لأخذ آراء عينة الدراسة من الخبراء عليها

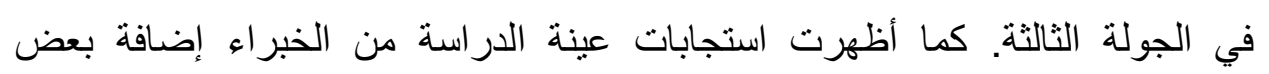
الأهداف المتمنلة في (التعامل بواقعية مع جهود تطوير برنامج الدبلوم العام في التربية وتنفيذها وفقاً لأولوياتها في إطار تعاوني)، وهو ما يتفق مع دراسة (أبو هرجة،

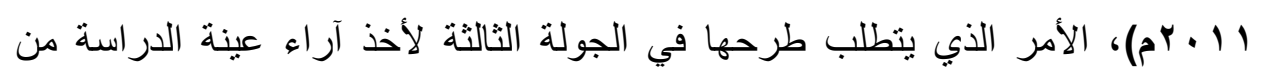
الخبر اء عليها.

كما أظهرت الاستجابات أيضاً؛ إضافة بعض المتطلبات المتمثلة في (التنسيق والتعاون المشترك بين الأقسام العلمية في تنفيذ بر امج وخطط العمل، وتعزيز قيمة التعلم 
إدارة أولويات برنامج الدبلوم العام في التربية بجامعة الأزهر في ضوء مدخل المقارنة المرجعية benchmarking

كجزء أساسي من أداء المشاركين بالبرنامج لمهامهم)، مما أدى لطرحها علي السادة الخبر اء في الجولة الثالثة.

وجاءت استجاباتهم في الجولة الثالثة حول ما تم التوصل إليه في الجولة الثانية

من منطلبات لازمة لإدارة أولويات برنامج الدبلوم العام في التربية بجامعة الأزهر، كما

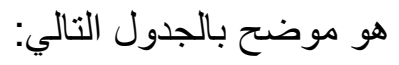

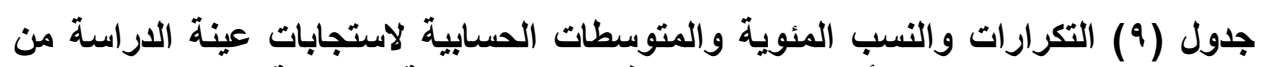

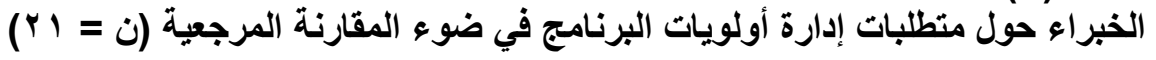

\begin{tabular}{|c|c|c|c|c|c|c|c|c|c|c|c|}
\hline \multirow{3}{*}{ الترتيب } & \multirow{3}{*}{ المو افقوى } & \multirow{3}{*}{ نمبة المواقق } & \multirow{3}{*}{ منوسطي } & \multicolumn{6}{|c|}{ درجة الموافقة } & \multirow{3}{*}{ العبـــــارة } & \\
\hline & & & & \multicolumn{2}{|c|}{ ضعيفة } & \multicolumn{2}{|c|}{ متوسطة } & \multicolumn{2}{|c|}{ كبيرة } & & \\
\hline & & & & $\%$ & 5) & $\%$ & ك & $\%$ & s & & \\
\hline \multicolumn{12}{|c|}{ ـ تحديد أهداف إدارة أولويات البرنامج في ضوء المقارنة المرجعية } \\
\hline 7 & كبيرة & $9 ., 0$ & $r, q$. & & & 9,0 & r & $9 ., 0$ & 19 & 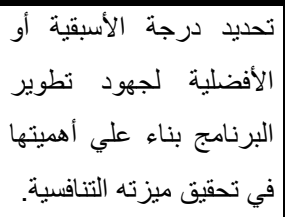 & \\
\hline$\varepsilon$ & كبيرة & $90, r$ & $r, 90$ & & & $\varepsilon, \wedge$ & 1 & $90, r$ & $r$. & 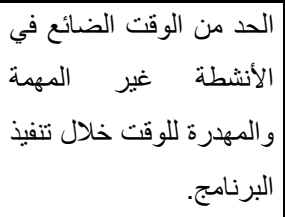 & $r$ \\
\hline 1 & كبيرة & $1 \ldots$ & $r, \ldots$ & & & - & - & $1 \ldots$ & rl & 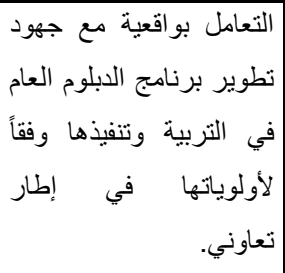 & r \\
\hline
\end{tabular}

العدد الخامس والاربعون (الجزء اللاول) ب r. r r

(88)

مجلة كلية التربية- جامعة عين شمس 
د/ أحمد عبد الفتاح حمدي الهنداوي

\begin{tabular}{|c|c|c|c|c|c|c|c|c|c|c|c|}
\hline \multirow{3}{*}{ الترتيب } & \multirow{3}{*}{ المو افقوى } & \multirow{3}{*}{ نسبة } & \multirow{3}{*}{ مستوسط } & \multicolumn{6}{|c|}{ درجة الموافقة } & \multirow{3}{*}{ العبــــارة } & \\
\hline & & & & \multicolumn{2}{|c|}{ ضعيفة } & \multicolumn{2}{|c|}{ | متوسطة } & \multicolumn{2}{|c|}{ 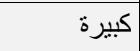 } & & \\
\hline & & & & $\%$ & ك) & $\%$ & 5) & $\%$ & 5] & & \\
\hline 1 & 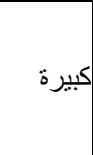 & $1 \ldots$ & $r, \ldots$ & & & - & - & $1 \ldots$ & r) & 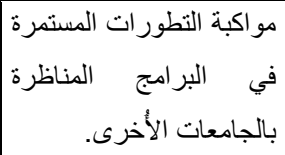 & $\varepsilon$ \\
\hline 1 & كبيرة & $1 \ldots$ & $r, \ldots$ & & & - & - & $1 \cdots$ & $r$ & 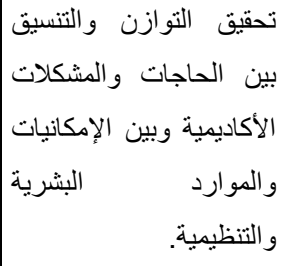 & 0 \\
\hline$\varepsilon$ & كبيرة & $90, r$ & $r, 90$ & & & $\varepsilon, \wedge$ & 1 & $90, r$ & $r \cdot$ & 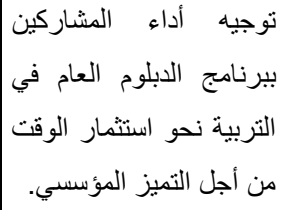 & 7 \\
\hline & & & & & & & & 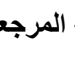 & 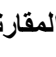 & دـ أفضل الممارسات موضع ا & ب - \\
\hline$r$ & كبيرة & $90, r$ & $r, 90$ & & & $\varepsilon, \wedge$ & 1 & $90, r$ & $r$. & عمع الفضل البيانات والمعلومات & \\
\hline 0 & كبيرة & $9 ., 0$ & $r, q$. & & & 9,0 & $r$ & $9,, 0$ & 19 & 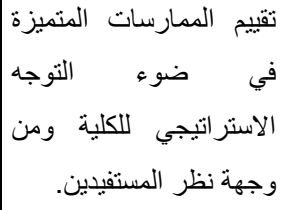 & $r$ \\
\hline$r$ & كبيرة & $90, r$ & $r, 90$ & & & $\varepsilon, \lambda$ & 1 & $90, r$ & $r \cdot$ & 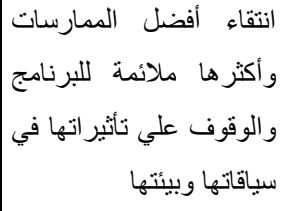 & $r$ \\
\hline
\end{tabular}

العدد الخامس والاربعون (الجزء الاول) ا r. r

(89)

مجلة كلية التربية- جامعة عين شمس 
إدارة أولويات برنامج الدبلوم العام في التربية بجامعة الأزهر في ضوء مدخل المقارنة المرجعية benchmarking

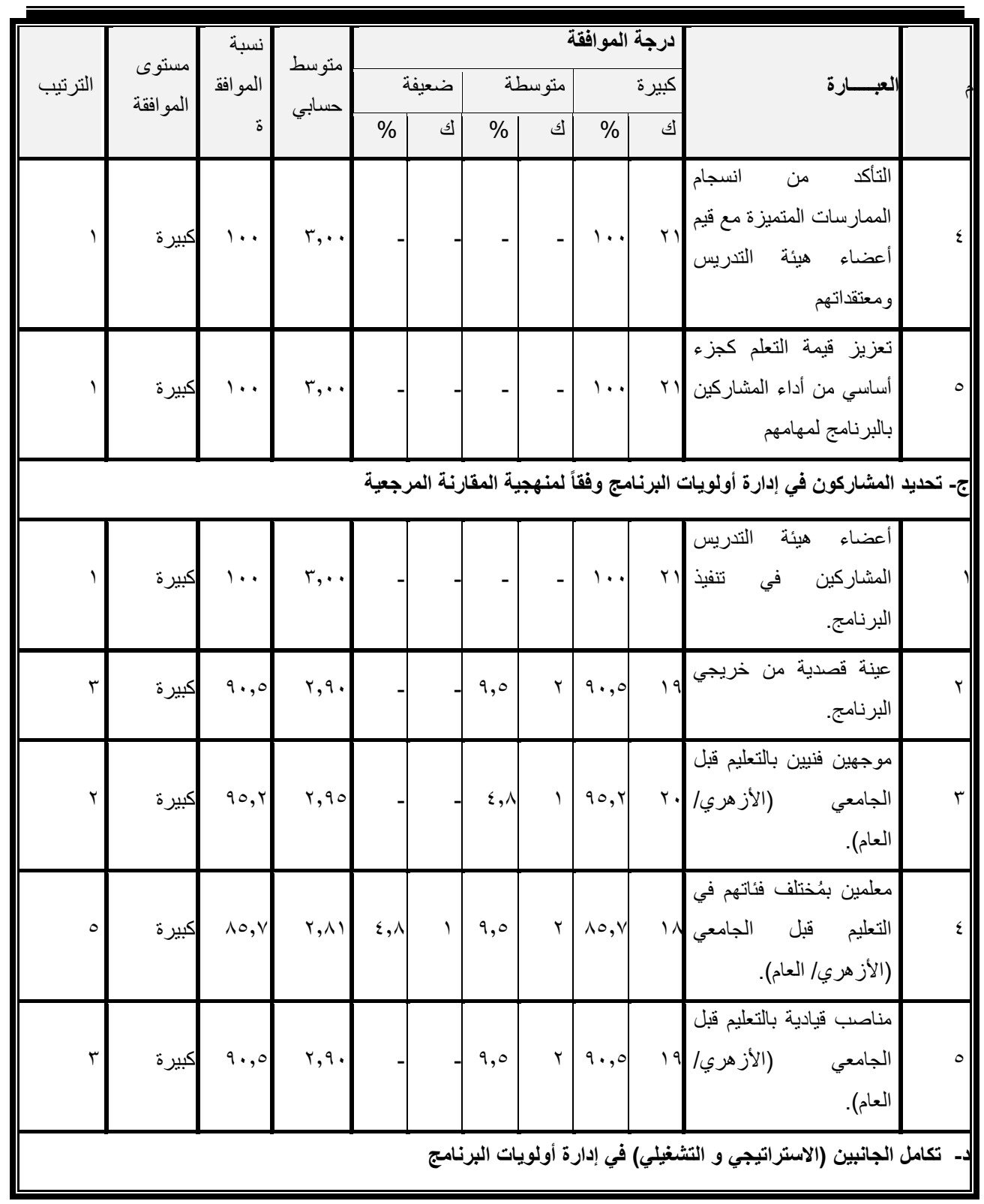

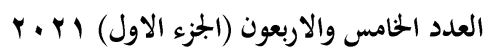

مجلة كلية التربية- جامعة عين شثس (90) 
د/ أحمد عبد الفتاح حمدي الهنداوي

\begin{tabular}{|c|c|c|c|c|c|c|c|c|c|c|c|}
\hline \multirow{3}{*}{ الترتيب } & \multirow{3}{*}{ المو افقة } & \multirow{3}{*}{ نالمبة } & \multirow{3}{*}{ حسابي } & \multicolumn{6}{|c|}{ لدرجة الموافقة } & \multirow{3}{*}{ العبـــــارة } & \\
\hline & & & & \multicolumn{2}{|c|}{ ضعيفة } & \multicolumn{2}{|c|}{ متوسطة } & \multicolumn{2}{|c|}{ 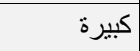 } & & \\
\hline & & & & $\%$ & ك & $\%$ & s] & $\%$ & 5) & & \\
\hline$\varepsilon$ & كبيرة & $10, \mathrm{v}$ & $r, \wedge l$ & $\varepsilon, \wedge$ & 1 & 9,0 & $r$ & $10, \mathrm{v}$ & in & 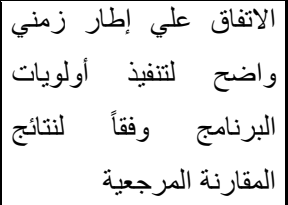 & \\
\hline r & كبيرة & $90, r$ & r,90 & & & $\varepsilon, \wedge$ & 1 & $90, r$ & $r$. & 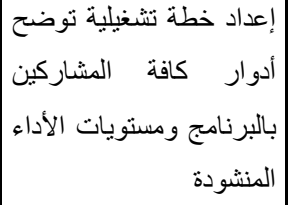 & r \\
\hline$r$ & كبيرة & $10, \mathrm{v}$ & r,AT & & & $1 \leqslant, \Gamma$ & $r$ & $10, \mathrm{~V}$ & in & 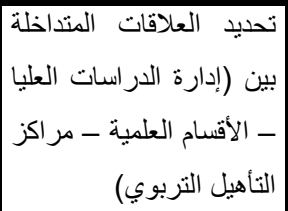 & $r$ \\
\hline 1 & كبيرة & $1 \ldots$ & $r, \ldots$ & & & - & - & $1 \cdots$ & rl & 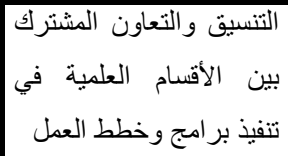 & $\varepsilon$ \\
\hline$\varepsilon$ & كبيرة & $\Lambda 0, \mathrm{v}$ & $r, \wedge 1$ & $\varepsilon, \wedge$ & 1 & 9,0 & r & $10, \mathrm{~V}$ & in & تلفيذ أولويات البرنامج بدراسة صعوبات & 。 \\
\hline & & & & & & & & & رنامج & سبية علي نتائج وإنجازات الب & هـ 1) - (1) \\
\hline$\varepsilon$ & كبيرة & 10, $\mathrm{v}$ & r,AT & - & & $1 \leqslant, \Gamma$ & r & $\wedge 0, \mathrm{v}$ & in & مراجئوليات المشاركين فية لتنفيذ مهام & \\
\hline$r$ & كبيرة & $90, r$ & $r, 90$ & & & $\varepsilon, \wedge$ & 1 & $90, \Upsilon$ & $r \cdot$ & 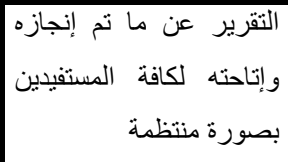 & $r$ \\
\hline 1 & كبيرة & $1 \ldots$ & $r, \ldots$ & & & - & - & $1 \cdots$ & r) & 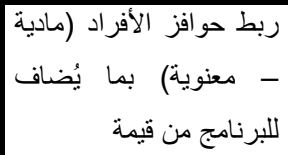 & $r$ \\
\hline
\end{tabular}

العدد الخامس والاربعون (الجزء الاول) ا Y.r.

مجلة كلية التربية- جامعة عين شثس (91) 
إدارة أولويات برنامج الدبلوم العام في التربية بجامعة الأزهر في ضوء مدخل المقارنة المرجعية benchmarking

\begin{tabular}{|c|c|c|c|c|c|c|c|c|c|c|c|}
\hline \multirow{3}{*}{ الترتيب } & \multirow{3}{*}{ المو افقة } & \multirow{3}{*}{ 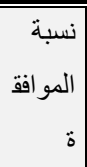 } & \multirow{3}{*}{ منوسط } & \multicolumn{6}{|c|}{ درجة الموافقة } & \multirow{3}{*}{ العبـــــارة } & \\
\hline & & & & \multicolumn{2}{|c|}{ ضعيفة } & \multicolumn{2}{|c|}{ متو سطة } & \multicolumn{2}{|c|}{ كبيرة } & & \\
\hline & & & & $\%$ & ك5 & $\%$ & ك5 & $\%$ & ك & & \\
\hline$\varepsilon$ & كبيرة & $10, \mathrm{~V}$ & T & & & $1 \leq, \Gamma$ & $r$ & $10, \mathrm{v}$ & iN & 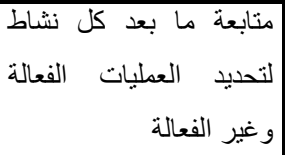 & $\varepsilon$ \\
\hline 1 & كبيرة & $1 \ldots$ & $r, \ldots$ & & & - & - & $1 \ldots$ & rI & 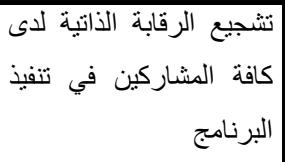 & 0 \\
\hline
\end{tabular}

من خلال الجدول السابق يتضح أن استجابات أفراد عينة الدراسة من الخبراء حول أهم المنطلبات اللازمة لإدارة أولويات برنامج الدبلوم العام في التربية بجامعة

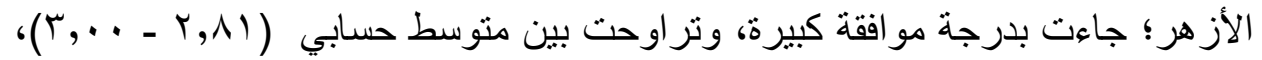
ونسب موافقة (10,〉 ـ . . ( )، الأمر الذي يعني تأكيد موافقة أفراد عينة الدراسة علي تللك المتطلبات.

خامساً: تصور مستقبلي لإدارة أولويات برنامج الابلوم العام في التربية بجامعة الأزهر في ضوء مدخل المقارنة المرجعية

من خلال العرض السابق؛ يمكن تقديم التصور المستقبلي لإدارة أولويات برنامج الدبلوم العام في التربية بجامعة الأزهر في ضوء مدخل المقارنة المرجعية،

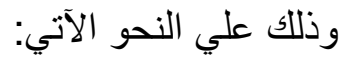
أ- فلسفة التصور المستقبلي تكمن فلسفة التصور المستقبلي في أن إدارة أولويات برنامج الدبلوم العام في التربية بجامعة الأزهر ليست مجرد تتظيم للوقت أو اختصاراً لإنجاز المهام المحددة

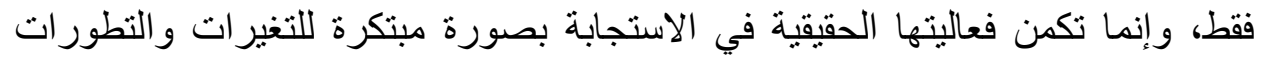




\section{د/ أحمد عبد الفتاح حمدي الهنداوي}

البيئية، وتحقيق أهداف البرنامج بأعلى فاعلية ممكنة، بحثاً عن أفضل الممارسات و الأساليب وتعظيم الاستفادة منها لتحقيق الميزة التنافسية للبرنامج.

$$
\text { ب- أهداف التصور المستقبلي }
$$

\section{يسعى التصور المستقبلي إلي تحقيق الأهداف التالية :}

تقديم إطارًا عملياً، مبنياً علي أسس علمية، لما ينبغي أن يكون عليه برنامج الدبلوم العام في التربية بجامعة الأزهر في المُستقبل؛ من وجود آلية شاملة لإدارة الأولويات في ضوء أفضل الممارسات بالبرامج المناظرة محلياً وعالمياً، بحيث تتكامل جهود كافة المشاركين في تحديد الأولويات وترتيبها وفقاً لأهميتها ومتابعة تنفيذها، ضماناً لجودة أداء البرنامج وقدرته علي التميز و المنافسة. - مساعدة كافة المستفيدين من برنامج الدبلوم العام في التربية بجامعة الأزهر (طلاب ـ أعضاء هيئة التدريس - إدارة جامعية ـ المؤسسات المجتمعية ذات العلاقة) علي القيام بدور إيجابي في تنفيذ أنشطة البرنامج وفقاً لأولوياته، وبما يتفق مع التغيرات و التطور ات المحلية والعالمية، من أجل تحقيق ميزته التنافسية. دعم التعاون والتنسيق بين مستويات إدارة البرنامج (إدارة جامعة الأزهر - إدارة كلية التربية ـ الأقسام العلمية ـ مر اكز التأهيل التربوي) بما يكفل المزيد من الدعم والمساندة لنجاح تتفيذ جهود البرنامج وفقاً لأولوياتها، والمساعدة على إيجاد فهم مشترك لجوانب الضعف وجو انب القوة في كافة مجالات العمل بالبرنامج وتحديدها و التعامل معها بشكل أكثر وضوحاً. توجيه القيادات الأكاديمية بجامعة الأزهر لتوفير كافة أشكال الدعم التي تكفل تعظيم الإفادة من أفضل الممارسات بالجامعات المُناظرة محلياً وعالمياً بما يُسهم في نجاح البرنامج وتحقيقه لأهدافه، مثل: منح إدارة البرنامج قدر مناسب من الاستقلالية،

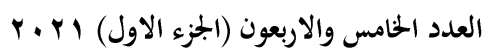

مجلة كلية التربية- جامعة عين شثس 
إدارة أولويات برنامج الدبلوم العام في التربية بجامعة الأزهر في ضوء مدخل المقارنة المرجعية benchmarking

وتقديم الدعم الفني اللازم، وتوفير الموارد الأساسية اللازمة من تجهيزات ووسائل تكنولوجية حديثة.

ج- أبعاد التصور المستقبلي

يمكن توضيح السياق العام لأبعاد التصور المستقبلي لإدارة أولويات برنامج الدبلوم العام في التربية بجامعة الأزهر في ضوء مدخل المقارنة المرجعية، من خلال

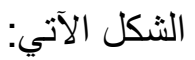
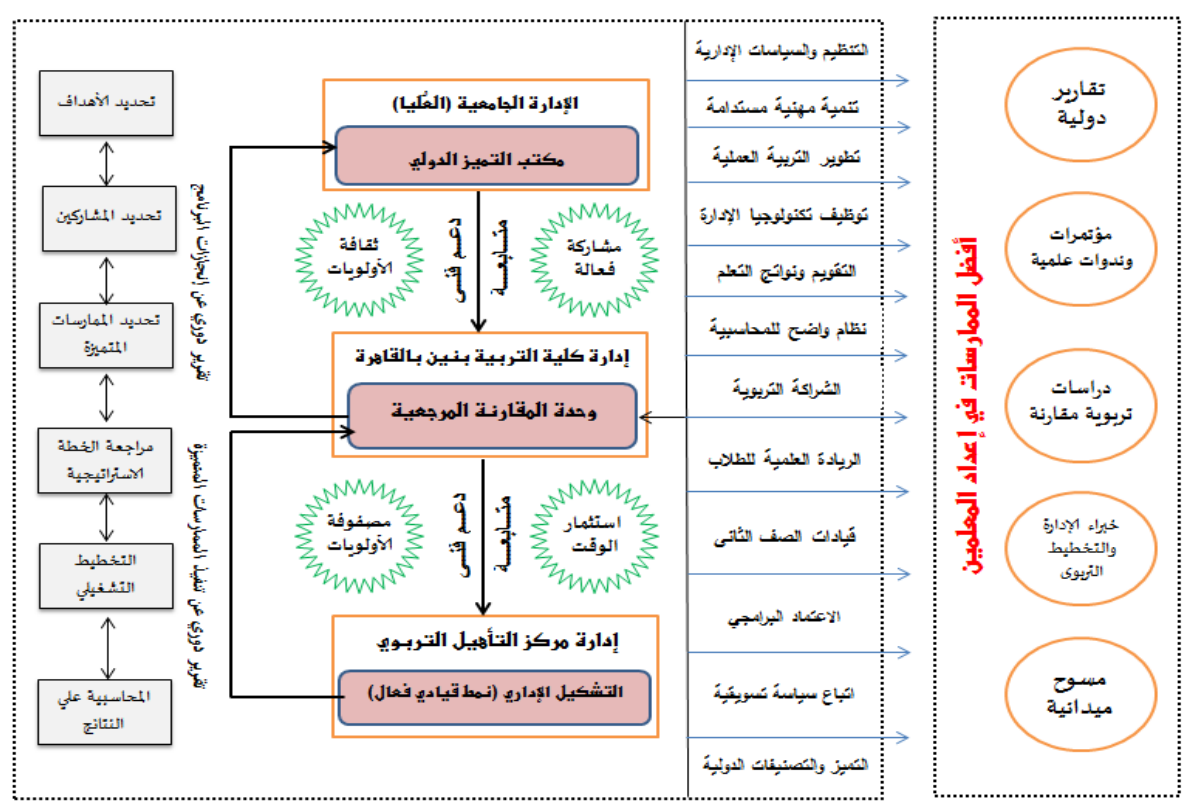

شكل (r) تصور مستقبلي لإدارة أولويات برنامج الابلوم العام في التربية بجامعة الأزهر في ضوء المقارنة المرجعية 
د/ أحمد عبد الفتاح حمدي الهنداوي

من خلال الثكل السابق؛ يمكن توضيح أبعاد التصور المستقبلي لإدارة أولويات التبات برنامج الدبلوم العام في التربية بجامعة الأزهر في ضوء مدخل المقارنة المرجعية،

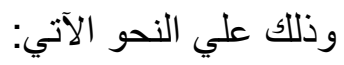

البعد الأول: أهم المجالات أو القضايا ذات الأولوية لبرنامج الدبلوم العام في التربية بجامعة الأزهر

هنالك العديد من المجالات و القضايا التي تُشكل إطاراً لإدارة أولويات برنامج الدبلوم العام في التربية بجامعة الازهر، والتي تُشهم في تحقيق التوجه الاستراتيجي للكلية و الجامعة، وتتفق مع استجابات أفر اد عينة الدراسة من ذوي الخبرة ــ المشاركين في إدارة البرنامج، وتستجيب لأبرز التطورات و التغيرات في برامج إعداد المعلم، وتتمثل هذه المجالات فيما يلي:

تثقيف كافة المشاركين بالبناء التظظيمي والسياسات الإدارية واللوائح الموجهة للعمل وفقاً للغرض منها، في إطار التكامل بين التنظيم الرسمي والتنظيم غير الرسمي بما يحقق الرضا الوظيفي لاى المشاركين في تنفيذ البرنامج، والعمل علي مراجعة الهيكل التنظيمي دورياً بشكل منهجي بما يسهل عملية الاتصال بين الوحدات الإدارية، وتفويض واضح للسلطة من قبل الإدارة العليا في جميع المستويات الإدارية، وتعديل التشريعات التي تسهم في تعظيم الاستفادة من الممارسات المتميزة، واعتماد ونشر توصيف وظيفي يوفر تحديداً واضحاً لواجبات ومسئوليات كل وظيفة، وصياغة سياسات إدارية واضحة تدعم وتوجه القرارات نحو تطوير الأداء الأكاديمي، وترسيخ الثقة بين كافة المشاركين بالبرنامج و المستويات الإدارية الأعلى.

تنفيذ برامج تدريبية لتحسين أداء المشاركين في البرنامج وفقاً لاحتياجاتهم المهنية، والعمل علي توفير فرص تنافسية لاستقطاب واختيار المشاركين في تنفيذ

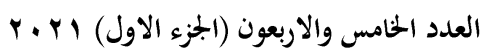

(95)
مجلة كلية التربية- جامعة عين شثس 
إدارة أولويات برنامج الابلوم العام في التربية بجامعة الأزهر في ضوء ملخل المقارنة المرجعية benchmarking

البرنامج وتبنى نظام للاختيار يقوم على استقطاب المواهب و الكفاءات، وتبنى سياسة و اضحة للتحفيز المادي والمعنوي من شأنها ثُزيد من إقبال المشاركين علي تطوير

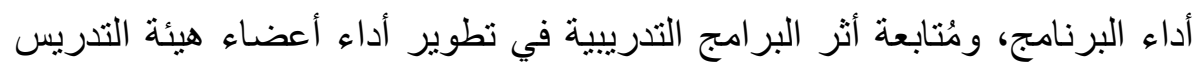
خلال تتفيذ البرنامج، واهتمام عملية تقويم الأداء بقياس مختلف الخصائص الثخصية والسلوكية المؤثرة فيه؛ منل: القدرة على الابتكار، و التجديد، و النضوج العاطفي، ومهارة الاتصال، والقدرة على التعاون، ومدى مساهمته في أداء فريق العمل، وتوفير قواعد مكتوبة ومعلنة للجميع توضح آليات التعامل مع مشكلات الأداء المنخفض، ومشكلات السلوك غير المرغوب فيه.

تطوير أنشطة التربية العملية وإجراءاتها في إحداث التكامل بين الجوانب النظرية والتطبيقية للبرنامج، من حيث تحديث اللائحة التنظيمية للتدريب الميداني بحيث يُوضح من خلالها الضوابط والمسؤوليات، وتحديد مهام وأدوار الطلبة في التنريب الميداني بصورة واضحة ومعلنة، وأن تكون مدة التدريب كافية للارسين، وتكامل فريق الإشراف من ذوي الخبرة التدريسية أعضاء هيئة التدريس، واختيارهم بناء علي تخصصات الطلاب، وتحديد آليات معتمدة لتقييم نتائج التدريب الميداني.

تفعيل دور وحدة التعليم الإكتروني والتعلم عن بُعد في توظيف تكنولوجيا المعلومات والاتصالات في الجواتب الإدارية للبرنامج، من خلال استكمال الأجهزة والأدوات اللازمة في القاعات الدراسية، وتوفير شبكة معلومات للعاملين تفيدهم في إنجاز الأعمال المشتركة بين الوحدات، وتدريب كافة العاملين على الاحتر افية في استخدام البرامج والمنصات الإلكترونية عن بُعد في العمل الأكاديمي والإداري، والعمل علي تحديث وصيانة الأجهزة اللازمة باستمرار لإنجاز العمل، ودعم العمليات الإدارية في مر اكز التأهيل التربوي إلكترونياً. 
د/ أحمد عبد الفتاح حمدي الهنداوي

- - إعادة النظر في عمليات تقويم الطلاب كأداة للتطوير والتحسين، و اعتمادها علي الفئي

نواتج التعلم، فضلاً عن توظيف نتائجه بشكل فعال في تصحيح مسار البرنامج

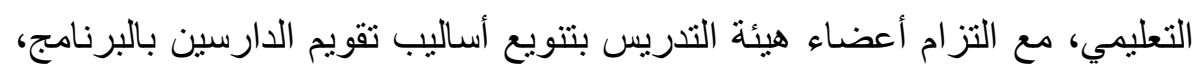
بحيث تتضمن: (مشاركة الدارسين أثناء المُحاضرات - تكليفهم بتقديم عروض صفية وتزويدهم بالتغذية الر اجعة ـ تقديم تكاليف أسبو عية - تقديم بُحوث جماعية ـ ملاحظة تفاعل الدارسين في المواقف المُختلفة - تكليفهم بإجراء البحوث بهنه باستخدام الوسائل التقنية الحديثة ـ تقديم بحوث فردية ـ تقديم أور اق عمل ـ طرح

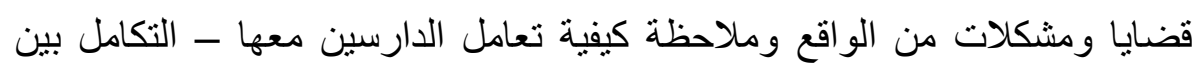
الاختبارات الثفوية والتحريرية ـ تقديم مشاريع بحثية ـ تكليف الدراسين بتقويم أداء زملائهم لبعض التكليفات).

تحديد إجراءات واضحة للمحاسبية وفقاً لنتائج وإنجازات البرنامج مقارنة بالبرامج المناظرة، من حيث وضرح القائم بالمحاسبية، و المعايير التي تتم المحاسبية في

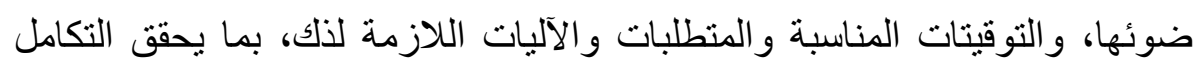
بين نواتج التعلم والمحاسبية لأعضاء هيئة التدريس، وإجر اء دراسات تطبيقية للتأكد من مدى تحقق نواتج التعلم المكتسبة لدى خريجي البرنامج وتطبيقها في المؤسسات التعليمية التي يعملون بها.

تفعيل الثراكة مع مؤسسات التعليم قبل الجامعي، من خلال علاقة نكاملية بين إمكانيات وقدرات (إدارات مراكز التأهيل التربوي بالمحافظات) و (المناطق الأزهرية والمعاهد في نطاق إثرافها)، بحيث يبرز التوافق والاتفاق حول تحسين

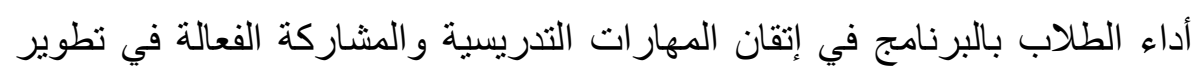
العملية التعليمية، مع تنويع الأساليب المستخدمة في ذلك من (زيارات ميدانية ـ ورش عمل - مشروعات نربوية - إنتاج وسائل تعليمية - و وغير ها)، مع احترام كل طرف لقرات وأداء الطرف الآخر، من خلال تعاون ناجح بستند إلي خطة

$$
\begin{aligned}
& \text { العدد الخامس والاربعون (الجزء الاول) ب. r. r. } \\
& \text { مجلة كلية التربية- جامعة عين شمس }
\end{aligned}
$$


إدارة أولويات برنامج الدبلوم العام في التربية بجامعة الأزهر في ضوء مدخل المقارنة المرجعية benchmarking

واضحة ومحددة تقوم علي تحمل المسئولية وتحديد الأدوار و المهام المنوطة بكل

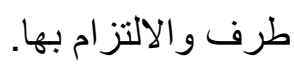

تنفيذ برامج إرشادية وتوعوية وتحفيزية للطلاب حول مقومات الريادة العلمية، بما يُسهم في تعزيز التقدير الذاتي والثقـة بـالنفس عن طريتق تعزيز وتغذية المواهب

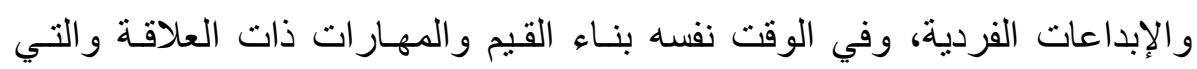

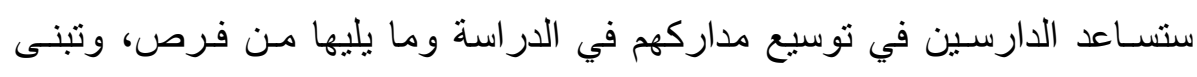

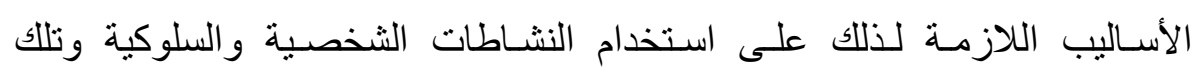
المتعلقة بالتخطيط لمسار المهنة.

إعداد قيادات الصف الثاني وجاهزيتهم للمشاركة في تنفيذ برامج الإصلاح ذات الأولوية، في إطار نمط قيادي يشجع أعضاء هيئة التدريس ورؤساء الأقسام العلمية

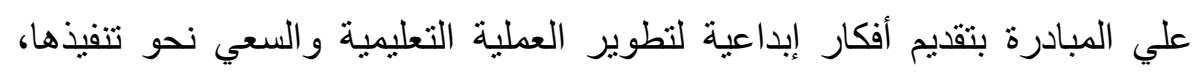
ومناقثة القرارات الإدارية بشكل جماعي مع المشاركين بالبرنامج، ومنح الأفراد

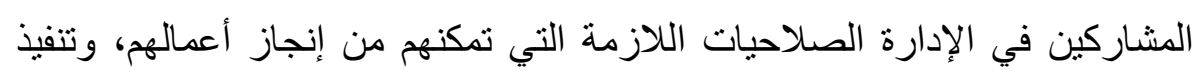

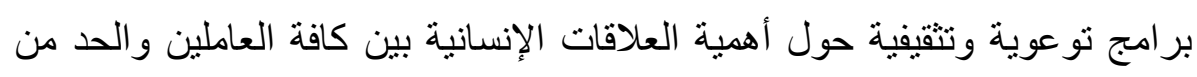

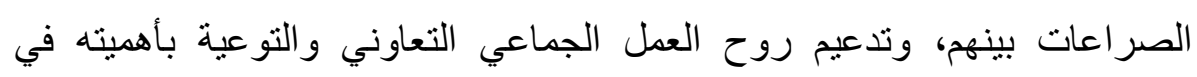
الارتقاء بالبرنامج وتميزه، وتوضيح قيم العدالة والموضوعية والجدية في تطبيق لهيق الجزاءات على المخالف لقواعد الانضباط، وتعزيز أصحاب السلوكيات الإيجابية و تشجيعهم وتكريمهم بشفافية ووضوح.

إعداد البرنامج للاعتماد من قبل الهيئة القومية لضمان جودة واعتماد المؤسسات التعليمية، من خلال رصد وتحديد مشكلات إعداد الدراسة الذاتية والتي ثُشكل عائق أمام تقدمها للاعنماد ووضع آليات للتغلب عليها، وتحديد إجراءات للمساءلة في

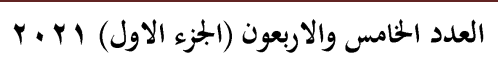

(98)
مجلة كلية التربية- جامعة عين شمس 
د/ أحمد عبد الفتاح حمدي الهنداوي

ضوء معايير ضمان الجودة والاعتماد ووضوحها لكافة المعنيين، وتوضيح الرؤية المستقبلية لكلية التربية بنين بالقاهرة ورسالتها و القيم الحاكمة لدى كافة المشاركين في تنفيذ البرنامج، وتفعيل المشاركة المجتمعية في ضوء معايير ضمان الجودة والاعتماد، وتفعيل دور الإدارة في مواجهة المشكلات السلوكية والاجتماعية و التعليمية في ضوء معايير جودة أداء الطالب، وتنفيذ المناهج والمقررات الدراسية وأنشطتها الصفية واللاصفية في ضوء معايير جودة أداء المنهج، ومتابعة تنفيذ

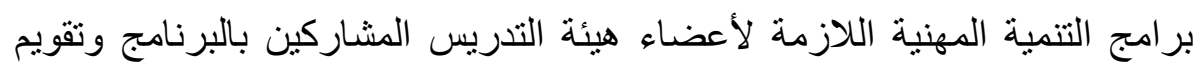
أدائهم في ضو هع معايير جودة أدائهم.

اتباع سياسة تسويقية توضح من خلالها إمكانات ونتائج البرنامج مقارنة بالبرامج المناظرة. من حيث تحديد وتحليل خصائص البيئة التي تعمل فيها مراكز التأهيل التربوي، ووضع خطة يمكن من خلالها توصيل الخدمات التي يمكن أن يقدمها

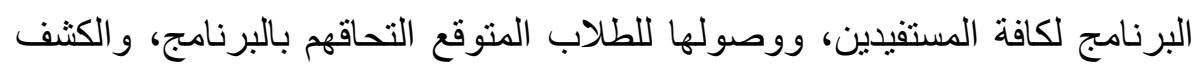
عن فرص البداية المتاحة أمامها، والقيود و التهديدات التي تؤثر على عملها، وتحديد أنشطة وإجر اءات التسويق ومتابعة تتفيذها وتقويمها.

الإعداد والتجهيز للمشاركة في جوائز التميز المؤسسي، من خلال العمل علي تذليل العقبات التي تواجه الموارد البشرية أثناء مراجعة تنفيذ معايير الجائزة، وإعلان أي إنجازات متحققة مقرونة بأسماء الأعضاء في الاجتماعات الدورية

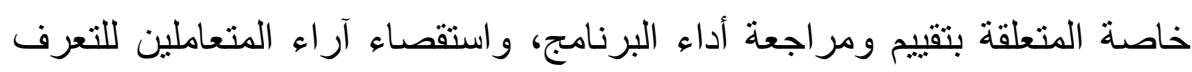
علي احتياجاتهم وتوقعاتهم من الخدمات التي يُقدمها البرنامج، واستطلاع التحسينات المطلوبة في الخدمات وفقاً لاحتياجات المستفيدين المستقبلية، ومقارنة رضا لهات المستفيدين من فترة زمنية لأخرى من خلال مقاييس شاملة تُغطى كافة جوانب

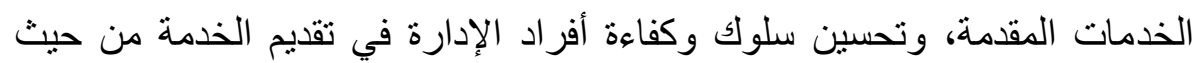


إدارة أولويات برنامج الابلوم العام في التربية بجامعة الأزهر في ضوء ملخل المقارنة المرجعية benchmarking

معالجة شكاوي المُتعاملين وزمن الاستجابة، وزيادة عدد المبادرات المجتمعية

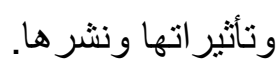

مراجعة التصنيفات الدولية لجودة التعليم والاستعداد للمشاركة فيها، من خلال المساعدة علي إكساب الطلاب الاتجاهات الإيجابية المرتبطة بالتعلم الذاتي، وتحفيز

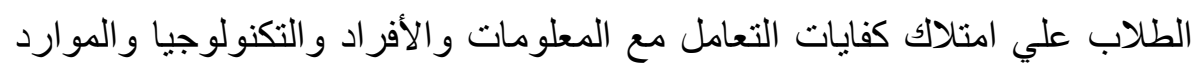
والنظم، والتقويم المستمر للمناهج والمقررات الدراسية وتوجيه أساليب توجيه المعارف والمهارات والاتجاهات في ضوء المستجدات والمتغيرات المحلية و العالمية، وتثجيع أساليب التدريس القائمة علي التفكير الإبداعي، وتعزيز الاستفادة من أساليب التقويم والاختبارات الدولية المُعاصرة، وتنمية قدرة أعضاء هيئة التدريس علي إدارة الوقت وحُسن استخدام الموارد التعليمية، وتنفيذ برامج إرشادية وتوعوية وتحفيزية للطلاب حول مقومات الريادة العلمية، والالتزام بقيم ومبادئ الديمقراطية والتشاور لدعم إمكانيات المشاركة في الاختبار ات الدولية وتبادل الآراء والأفكار للتوصل إلي حلول أفضل، وتكامل تطبيق مبادئ المحاسبية والتنافسية و الثفافية في العمل الإداري، وتحفيز وجود إرادة لدي كافة المشاركين في البرنامج لإحداث الإصلاحات التعليمية المنشودة.

البعد الثاني: متطلبات إدارة أولويات برنامج الدبلوم العام في التربية بجامعة الأزهر. هناك مجموعة من المتطلبات اللازمة لإدارة أولويات برنامج الدبلوم العام في

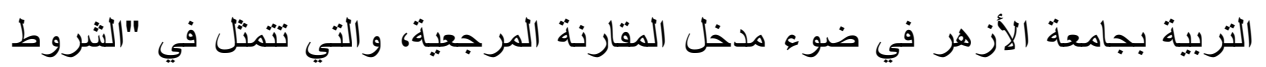
و الإجر اءات والتغييرات التي تُساعد علي تحديد أولويات البرنامج وترتيبها وتنفيذها وفقاً لأهميتها في تحقيق ميزته التنافية"، ويمكن توضيح هذه المتطلبات علي النحو التالي:

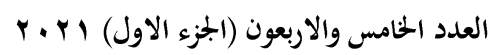

(100)

مجلة كلية التربية- جامعة عين شمس 
د/ أحمد عبد القتاح حمدي الهنداوي

ا . تحديد أهداف إدارة أولويات برنامج الابلوم العام في التربية بجامعة الأزهر في

ضوء مدخل المقارنة المرجعية

إن التطبيق الذي لا يعتمد علي فكر يوجهه و أهداف يسعي لتحقيقها هو عمل عشوائي لا جدوى من ورائه، وبالتالي لا بد من وجود أهداف توضح سبل الاستفادة من إدارة أولويات برنامج الدبلوم العام في التربية بجامعة الأزهر في ضوء مدخل المقارنة المرجعية عند تنفيذها علي أرض الواقع. وبناء عليه؛ تتمثل أهداف إدارة أولويات برنامج الدبلوم العام في التربية بجامعة الأزهر فيما يلي: (تحديد درجة الأسبقية أو الأفضلية لجهود تطوير البرنامج بناء علي أهميتها في تحقيق ميزته التنافسية ـ الحد من الوقت الضائع في الأنثطة غير المههة والمهرة للوقت خلال تنفيذ البرنامج - التعامل بواقعية مع جهود تطوير برنامج الدبلوم العام في التربية وتنفيذها وفقاً لأولوياتها في إطار تعاوني - مواكبة التطورات المستمرة في البرامج المناظرة بالجامعات الأُخرى - تحقيق التوازن والتنسيق بين الحاجات و المشكلات الأكاديمية وبين الإمكانيات و الموارد البشرية و التنظيمية ـ توجيه أداء المشاركين ببرنامج الدبلوم العام في التربية نحو استثمار الوقت من أجل التميز المؤسسي).

ץ. تحديا أهم الفئات المُشاركة في إدارة أولويات البرنامج وفقاً لمدخل المقارنة المرجعية

من الضروري أن تجمع هذه الفئات بين (الخبرة العلمية والبحثية في مجال إعداد المعلم) و(الخبرة الميدانية في مؤسسات التعليم قبل الجامعي)، من خلال تشكيل فريق القياس المرجعي المُقارن تحت إثر اف إدارة الكلية مباشرة لقيادة عمليات انتقاء وتوظيف الممارسات المتميزة، بحيث بتضمن أعضاء هيئة التدريس المشاركين في تنفيذ البرنامج، وعينة قصدية من خريجي البرنامج المتميزين، وموجهين فنيين بالتعليم قبل الجامعي (الأز هري/ العام)، ومعلمين بمُختلف فئاتهم في التعليم قبل الجامعي (الأزري/

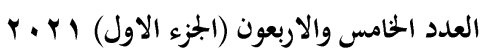

(101)

مجلة كلية التربية- جامعة عين شمس 
إدارة أولويات برنامج الابلوم العام في التربية بجامعة الأزهر في ضوء ملخل المقارنة المرجعية benchmarking

العام)، ومناصب قيادية بالتعليم قبل الجامعي (الأزهري/ العام)، ويقوم الفريق بإجراء مسوح ميدانية لتحديد احتياجات مؤسسات التعليم قبل الجامعي من المعلمين، وتحليل مضمون شكاوي وطلبات العاملين بمؤسسات التعليم قبل الجامعي والمستقيدين منها، وتنظيم جلسات استماع لأعضاء هيئة التدريس و الطلاب وكافة المستقيدين من البرنامج، ومراجعة التقارير الدولية والدراسات والبحوث المتخصصة حول تقويم/ تطوير برنامج الدبلوم العام في التربية بجامعة الأزهر، ومر اجعة توصيات المؤتمرات و الندوات العلمية

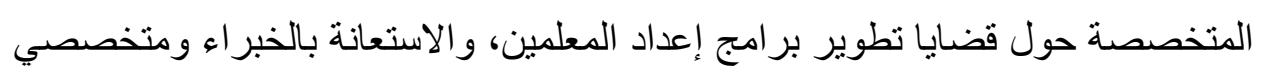
الإدارة والتخطيط التربوي في بناء تصورات ورؤى مستقبلية، وتثقيف كافة العاملين بآليات المقارنة المرجعية وتشجيعهم علي المنشاركة الفعالة في أنشطتها بشكل جماعي وني تعاوني.

r. تحديد أفضل الممارسات موضع المقارنة المرجعية

يتم تحديد أفضل الممارسات موضع المقارنة المرجعية من خلال جمع البيانات والمعلومات عن أفضل الممارسات في مجال إعداد المعلم وفقاً للنماذج التي ثبت نجاحها، ثم تقييم الممارسات المتميزة في ضوء التوجه الاستراتيجي للكلية ومن وجهة نظر

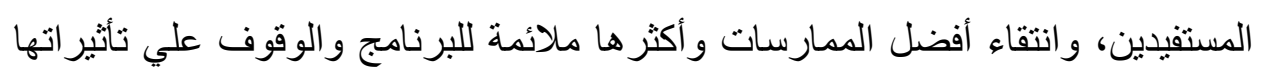

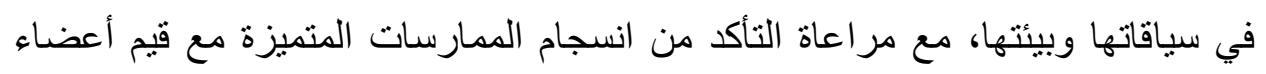
هيئة التدريس ومعتقداتهم والتوفيق بينها، ثم تبني وتكييف الممارسات المتميزة التي تم

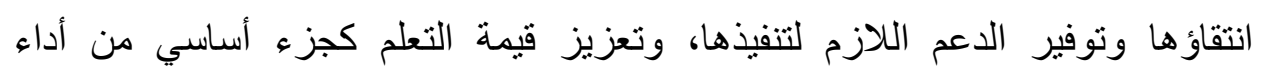

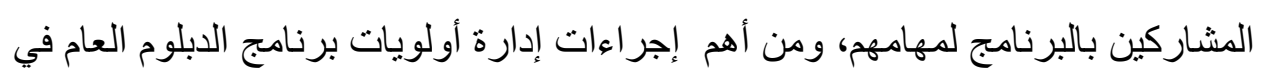
التربية بجامعة الأز هر في ضوء مدخل المقارنة المرجعية ما يلي:

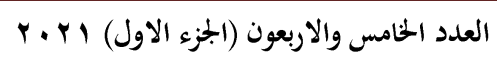

(102)

مجلة كلية التربية- جامعة عين شمس 


\section{د/ أحمد عبد الفتاح حمدي الهنداوي}

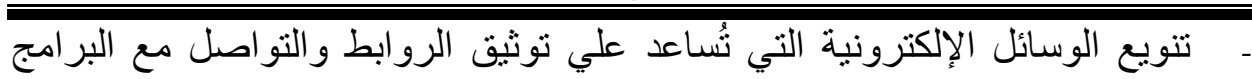

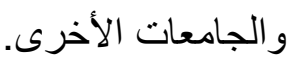

مر اجعة أهداف البرنامج بناء علي إنجازات البر امج المناظرة في الكليات المعتمدة. عرض وتحليل مضامين الموضوعات المقررة في البرامج المناظرة وتحديد مدى الإفادة من منهجية التكامل بينها. مقارنة نتائج جهود الأداء الوظيفي للمشاركين في البرنامج بنتائج جهود أقرانهم

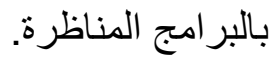
رصد الأفكار الإبداعية من البرامج المناظرة في الجامعات الأخرى. الاطلاع علي أساليب تسويق وترويج البرامج المناظرة في الكليات الأخرى لجذب

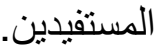
رصد جهود الثراكة بين كليات التربية ومؤسسات التعليم قبل الجامعي في دعم التطبيقات العملية للبرنامج. الاستفادة من أنشطة التربية العملية بالبرامج المناظرة في تحقيق التكامل بين النظرية

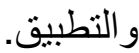

توظيف استر اتيجيات التقويم الحديثة المستخدمة في البر امج المتميزة. الاطلاع علي تطورات البر امج المناظرة في الجامعات الر ائدة (محلياً وعالمياً). - التو اصل مع الزملاء في التخصص بالجامعات المتميزة و الاستفادة من خبراتهح. - المبادرة في عمل النشاطات الموجهة (اللاصفية) بناء علي تجارب البرامج الأخرى في النشاطات الجامعية. - تنويع استر اتيجيات التدريس بناء علي المستخدمة في البرامج الأكثر تميزاً. - متابعة تكريم البرامج المتميزة وحيثياتها والاهتمام بالتصنيف العالمي للجامعات وموقع بر امج جامعة الأز هر منه. 
إدارة أولويات برنامج الدبلوم العام في التربية بجامعة الأزهر في ضوء مدخل المقارنة المرجعية benchmarking

\section{- التوازن بين (الرؤي والاستراتيجيات - العطيات و الإجراءات - النتائج و الإنجاز ات) للبر امج المناظرة.}

\section{؛. تكامل الجانبين (الاستراتيجي و التشغيلي) في إدارة أولويات البرنامج}

يعتبر التخطيط التشغيلي الأداة التنفيذية للتخطيط الاستر اتيجي؛ من خلال ربط الأهداف الاستراتيجية بالأهداف التكتيكية وتحويلها إلى برامج ومشاريع سنوية، فهو

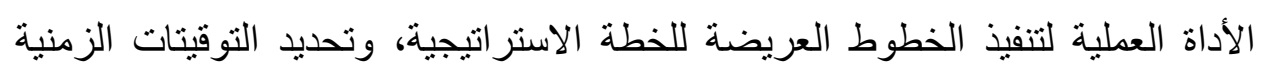
لانطلاق الششاريع ونهايتها, وتحديد المسئوليات التنفيذية ووضع الجدول الزمني لسير العمليات المتعلقة بأنشطة المشروع، ويركز الأداء التشغيلي على التفاصيل الإجرائية للطرق أو الاستر اتيجيات التي تستخدم لتحقيق أهداف وغايات ورسالة الكلية، ويجب أن أن النئن تحتوي الخطط التشغيلية على جانب تفصيلي كبير بالقدر الذي يغطي أهمية كل مجال من

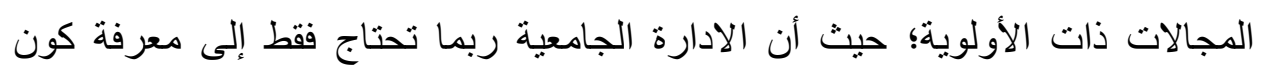
الهدف يخضع إلى التنفيذ حسب الجدول المتفق عليه , ولا تحتاج إلى معرفة التفاصيل

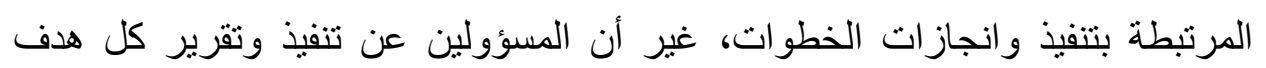
سوف يحتاجون إلى أكبر قدر ممكن من التفاصيل، الأمر الذي يتطلب ما يلي: - المراجعة المستمرة للخطة الاستر اتيجية للكلية في ضوء الممارسات المتميزة التي يتم التوصل إليها. - الاتفاق علي إطار زمني واضح لتنفيذ أولويات البرنامج وفقاً لنتائج المقارنة

$$
\text { المرجعية }
$$

- إعداد خطة تشغيلية توضح أدوار كافة المشاركين بالبرنامج ومستويات الأداء

$$
\text { المنشودة }
$$

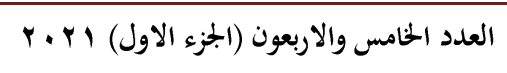

مجلة كلية التربية- جامعة عين شمس 
د/ أحمد عبد الفتاح حمدي الهنداوي

- تحديد العلاقات المتداخلة بين (إدارة الدراسات العليا ـ الأقسام العلمية ـ مر اكز

التأهيل التربوي)

- التتسيق و التعاون المشترك بين الأقسام العلمية في تنفيذ بر امج وخطط العمل - - الانتمام بدر اسة صعوبات تتفيذ أولويات البرنامج

ويعد التكامل بين (الخطة الاستراتيجية للكلية) و (الخطة التشغيلية لبرنامج

الدبلوم العام في التربية) أمراً جوهرياً لتحقيق الرؤية المستقبلية للكلية، وتعزيز أوجه الهنه التعاون والتنسيق في مجالات الإعداد والتنفيذ والمتابعة ومواجهة ما ينشأ من مشكلات خلالها، حيث إن هدف كل منهما واحد، حيث تأتي الخطط التشغيلية تجزئة و اقعية للخطة الاستر اتيجية، ولكن ما يظهر من اختلاف بينهما إنما هو اختلاف وظيفي يتعلق بطبيعة أدوار القائمين علي كل منهما، فالخطة الاستراتيجية والخطط التشغيلية المُنبثقة عنها وجهان مُختلفان لعُعلة واحدة، أي أن العلاقة بينهما يجب أن تكون علاقة تكامُلية سعياً لتحقيق الكفاءة والفعالية اللتين لا تتحققان إلا بتكامل الجانبين (الاستر اتيجي و التشغيلي). هـ المحاسبية علي نتائج و إنجازات البرنامج

يمكن من خلال المحاسبية Accountability التعرف على مدى تحقيق معايير جودة الأداء الثامل للبرنامج، فعن طريق المحاسبية يتم تقديم أساليب الثواب التي تعزز ملثري

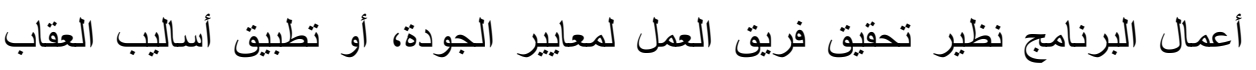
ومطالبتهم بمزيد من بذل الجهود اللازمة لتطوير الأداء في حال عدم تحقيقها معايير

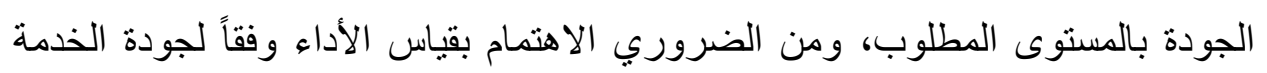
المقدمة، من حيث الالتزام بتنفيذ الأعمال والمهام في الوقت المحدد، وسرعة الاستجابة لاحتياجات المستفيدين و الرد علي استفسار اتهم، وتوفير سجلات دقيقة يمكن الرجوع إليها بشكل سريع، وابتكار أساليب جديدة نتناسب مع التغيرات في البيئة المحيطة. الأمر الذي لئي يتطلب إجر اء مر اجعة دورية لتنفيذ مهام ومسئوليات المشاركين في البرنامج، والتقرير

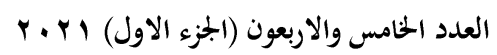

(105)
مجلة كلية التربية- جامعة عين شمس 
إدارة أولويات برنامج الدبلوم العام في التربية بجامعة الأزهر في ضوء مدخل المقارنة المرجعية benchmarking

عن ما تم إنجازه و إتاحته لكافة المستفيدين بصورة منتظمة، وربط حو افز الأفراد (مادية - معنوية) بما يُضاف للبرنامج من قيمة، ومتابعة ما بعد كل نشاط لتحديد العمليات الفعالة وغير الفعالة، وتشجيع الرقابة الذاتية لادى كافة المشاركين في تتفيذ البرنامج. د- الصعوبات التي يمكن أن تُشكل عائقاً أمام إدارة أولويات البرنامج هناك العديد من الصعوبات التي يمكن أن تواجه إدارة أولويات البرنامج وفقاً

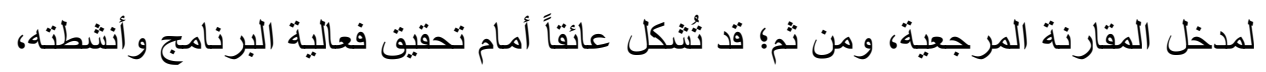

$$
\text { ومن أهم هذه الصعوبات ما يلي: }
$$

- الافتقار الي ثقافة تنظيمية تشجع على تنفيذ الخطة الاستر اتيجية، بالإضافة إلي قلة

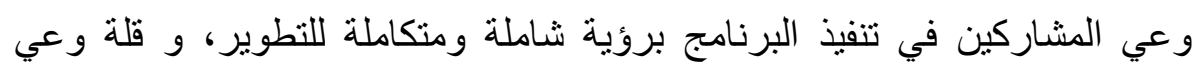

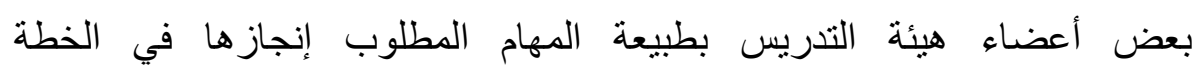
الاستر اتيجية، ويمكن التغلب على ذلك من خلال تغيير الثقافة السائدة لدى المشاركين

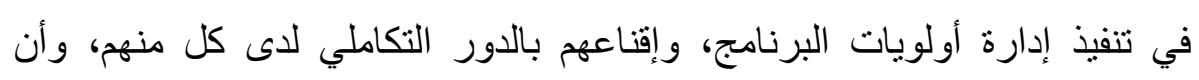

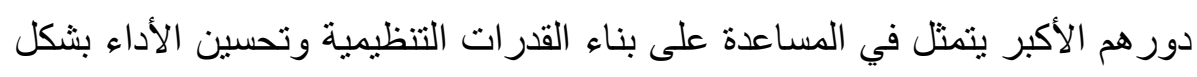
مستمر، وتوفير دليل (إلكتروني - ورقي) شامل، يوضح أبعاد التطوير في إطار رؤية الكلية ورسالتها. - قلة حوافز أعضاء هيئة التدريس مقارنة بما هو مطلوب منهم، وقلة نوافر مصادر

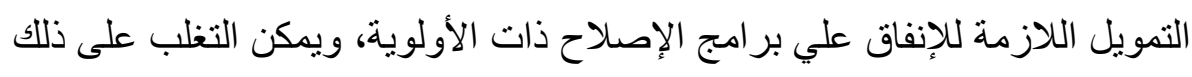

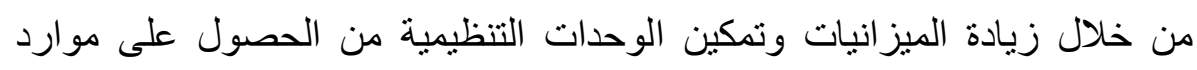
إضافية/ تمويل ذاتي، وتتجيع بعض مؤسسات المجتمع المحلي على المشاركة في

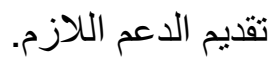

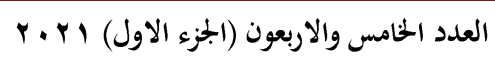

مجلة كلية التربية- جامعة عين شمس 
د/ أحمد عبد الفتاح حمدي الهنداوي

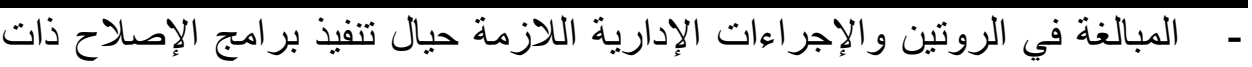
الأولوية، و كثرة الأعباء الفنية والإدارية الملقاة على عاتق أعضاء هيئة التدريس الإداه بالكلية، ويمكن التغلب على ذلك من خلال اتخاذ مجموعة من الإجر اءات التي تساعد على تحقيق التوافق بين القيم التنظيمية بالكلية وقيم العاملين بها، والتي من بينها: اتفاق إدارة الكلية مع العاملين على مجموعة من الموجهات و الممارسات التي تدعم

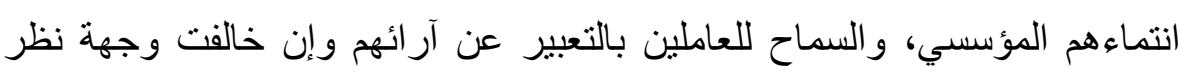

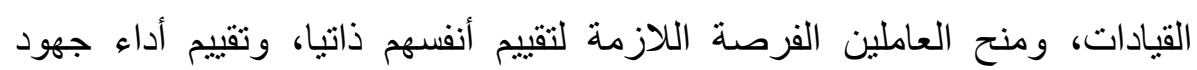
البرنامج في إطار تعاوني.

- ق قلة الاهتمام بتدريب العاملين علي تنفيذ الخطة الاستراتيجية، ويمكن التغلب على ذللك من خلال تفعيل دور وحدة ضمان الجودة بالكلية في التحديد الدقيق للاحتياجات

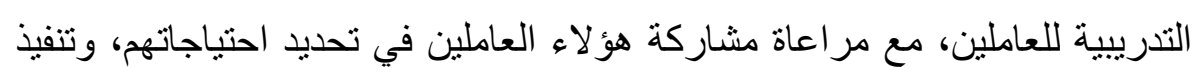
برامج التنمية المهنية التي تجعل العاملين قادرين على الوفاء بالمتطلبات اللازمة

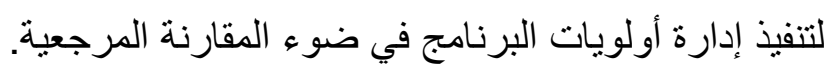
- عدم وجود معايير محددة لقياس رضا المستفيدين عن الخدمات المقدمة لهم، ويمكن التغلب على ذلك من خلال تفعيل دور وحدة ضمان الجودة بالكلية في توفير الوثائق الصادرة عن الهيئة القومية لضمان جودة التعليم والاعتماد، والخاصة بالاعتماد البرامجي لقطاع التربية، والاستعانة بها في قياس رضا المستفيدين عن الخدمات المقدمة لهم، وتقديم الدعم اللازم لتنفيذها.

- ضعف نظم المعلومات التي يمكن الاعتماد عليها في تنفيذ الخطة الاستراتيجية للكلية، ويمكن التغلب على ذلك من خلال تفعيل دور وحدة التعليم الإلكتروني والتعليم عن بُعد بالتعاون مع وحدة ضمان الجودة بالكلية في إنشاء قاعدة بيانات

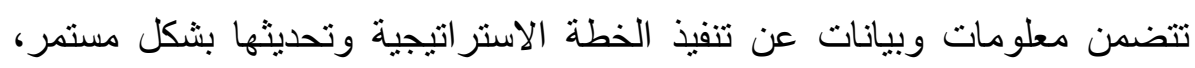


إدارة أولويات برنامج الدبلوم العام في التربية بجامعة الأزهر في ضوء مدخل المقارنة المرجعية benchmarking

واستثمار التكنولوجيا الحديثة في تحقيق التواصل بين كافة المستفيدين وبعضهم البعض.

- يادة حدة الصراعات بين المشاركين في البرنامج، ويمكن التغلب على ذلك من خلال مر اعاة العدالة في توزيع المهام المطلوبة على كل عضو داخل فريق العمل، والاعتناء بالمبدعين وتثجيعهم على الابتكار، وتفعيل دور إدارة البرنامج في توري توظيف استراتيجيات إدارة الصراع، والبحث عن بدائل مناسبة كتحقيق التكامل بين الحو افز (المادية والمعنوية) لمن يتعاون ويُشتارك بفعالية في إدارة أولويات البرنامج

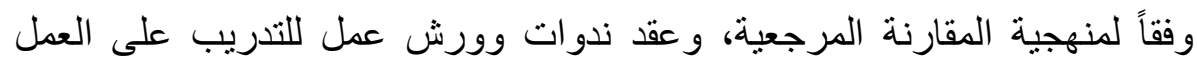
الجماعي و التعاوني.

- جمود بعض التشريعات وإعاقتها لتنفيذ برامج الإصلاح ذات الأولوية، ويمكن التغلب على ذلك من خلال إجراء بعض التعديلات التشريعية التي تمنح لإدارة

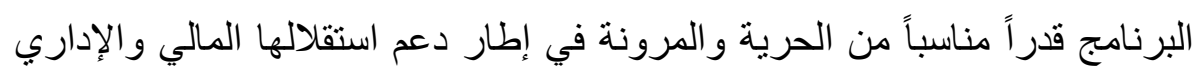

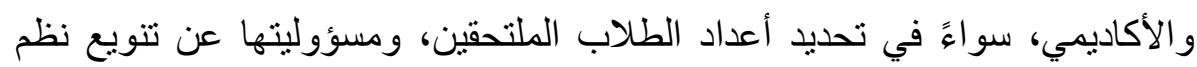
التقويم والامتحانات، ولوائح الكلية، بما يقلل من أعباء الإدارة الجامعية في الكثير من المهام التفصيلية الخاصة بالبرنامج. - زيادة حجم المستفيدين من خدمات برامج الإصلاح ذات الأولوية حيال تتفيذها، مع

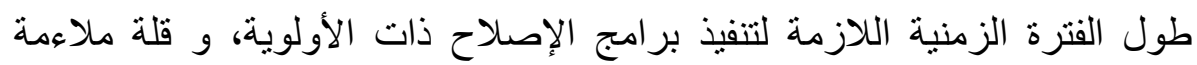
بر امج الإصلاح ذات الأولوية لرغبات كافة المستفيدين، ويمكن التغلب على ذلك من الإنس خلال العمل على تنفيذ إدارة أولويات البرنامج بشكل تدريجي، حتى يمكن التأكد من لن تغيير المعتقدات والمفاهيم المتعلقة بإدارة الأولويات في ضوء المقارنة المرجعية، 
د/ أحمد عبد الفتاح حمدي الهنداوي

وتهيئة أعضاء هيئة التدريس بإكسابهم المعارف والاتجاهات و القيم والمهار ات التي

تُساعدهم علي قبول هذا التصور وفقاً للغرض منه.

سادساً: توصيات الاراسة

في إطار الهدف من الدراسة والنتائج التي توصلت إليها؛ يمكن تقديم عدداً من التوصيات التي يمكن أن تُسهم في إدارة أولويات برنامج الدبلوم العام في التربية بجامعة الأز هر في ضوء مدخل المقارنة المرجعية، وذلك علي النحو الآتي:

- أن تتبني إدارة كلية التربية بنين بالقاهرة - جامعة الأزهر؛ خطة وسياسة واضحة المعالم لتحديد أولويات برنامج الدبلوم العام في التربية وترتيبها ومتابعة تتفيذها وفقاً لمنهجية المقارنة المرجعية، متضمنة الأولويات بين الأهداف، والأولويات بين المشروعات، والأولويات بين الأنشطة والممارسات، مع مراعاة شمولها لكافة مكونات البرنامج، بما يُسهم في تحقيق رؤية الكلية ورسالتها في إطار عالمي دينامي متغير.

ضمان التكامل بين (الثفافية في إدارة أولويات برنامج الدبلوم العام في التربية بجامعة الأز هر) و (المساءلة وفقاً لنتائج و إنجاز ات التطوير)، بما بعكس مدى التزام كافة المشاركين في البرنامج بإنجاز المهام؛ وفقاً لأهميتها في مواكبة التطورات المتجددة في مجال إعداد المعلمين، وفي التوقيت المناسب لها.

توفير قاعدة بيانات تتضمن نتائج (بحوث - در اسات ـ مؤتمرات - تقارير دولية) حول تطوير بر امج إعداد المعلم، وتحديثها بشكل مستمر. تتفيذ ورش عمل ودورات تدريبية لتمية قدرات أعضاء هيئة التدريس بالكلية في مجال استثمار الوقت و إدارة الأولويات، وتوظيف الخبرات الناجحة حول مجال إعداد المعلم في تنفيذ فعاليات البرنامج. 
إدارة أولويات برنامج الدبلوم العام في التربية بجامعة الأزهر في ضوء مدخل المقارنة المرجعية benchmarking

- تقديم بر امج تحفيزية للمشاركين في تنفيذ برنامج الدبلوم العام في الثربية بجامعة

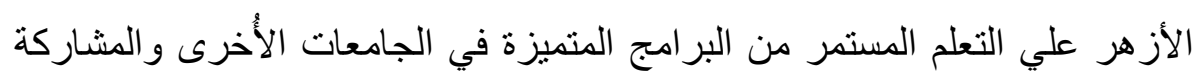
بفعالية في توظيف الخبرات الناجحة.

- - تعزيز العلاقات التعاونية والتشاركية الإيجابية بين إدارة برنامج الدبلوم العام في

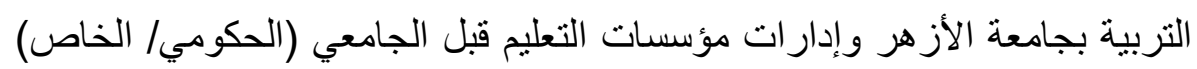
(العام/ الأزهري)، من أجل بناء جسور من التقة والتعاون بينهم في تنفيذ الجوانب التطبيقية للبرنامج، وتنويع البدائل.

توجيه اهتمام الباحثين بالكلية نحو إجراء بحوث علمية حول الاتجاهات العالمية الحديثة في برامج إعداد المعلم وإمكانية الإفادة منها في برنامج الدبلوم العام في لهي التربية بجامعة الأزهر .

تفعيل الدور الإعلامي بكلية التربية بنين بالقاهرة في نشر الوعي بين كافة المستفيدين بأهمية تحديد أولويات البرنامج وترتيبها وفقاً لفاعليتها في تحقيق الميزة التنافسية للبرنامج.

تعديل التشريعات التي من شأنها منح إدارة البرنامج قدر مناسب من الاستقلالية

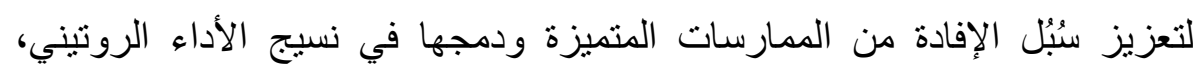
وتوفير الموارد و الإمكانات اللازمة لتعزيز سُبُل الاستفادة من الممارسات المتميزة. - إجراء مسابقات سنوية تساعد علي تصنيف وترتيب مراكز التأهيل التربوي علي

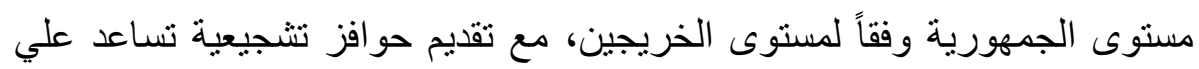
رفع مستوى الأداء. 


\section{قائمة المراجع}

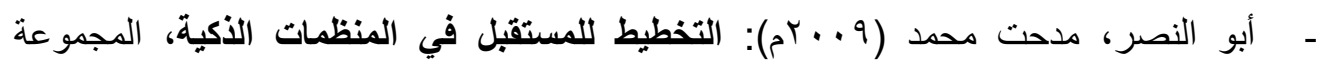
العربية للندريب والنشر، القاهرة.

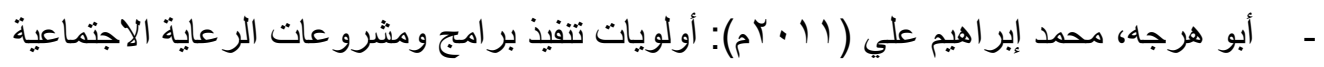

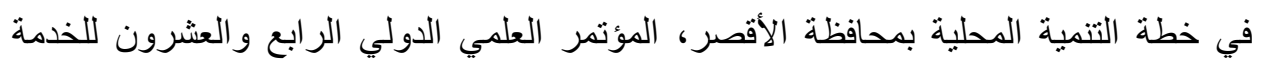

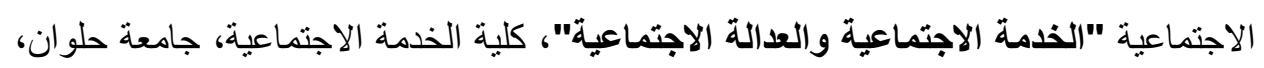

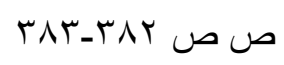

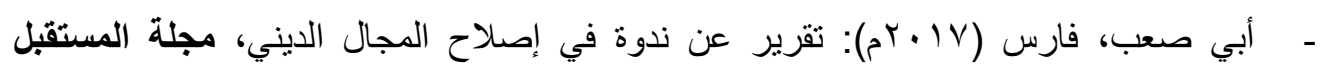

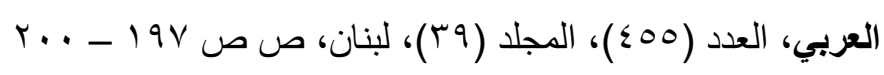

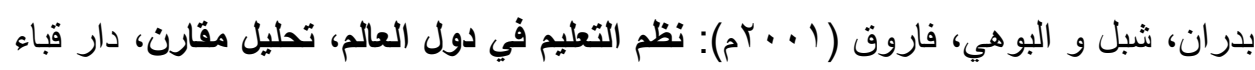

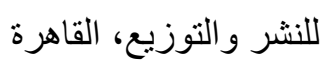
بوهالى، رتيبة و بلالطة، مبارك (1/ • rم): نموذج مقترح للمقارنة المرجعية في الجودة للجامعات العربية- دراسة مقارنة بين جامعة جيجل الجزائرية والجامعة الأردنية، المجلة

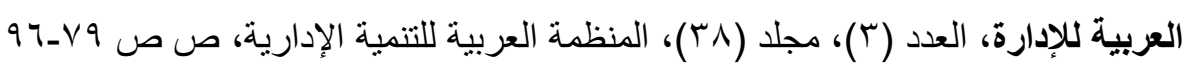
جابر، جابر عبد الحميد (·. . . مدرس القرن الحادي والعشرين الفعال ـ المهارات والتنمية المهنية، دار الفكر العربي، القاهرة.

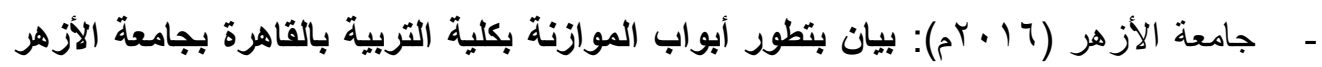

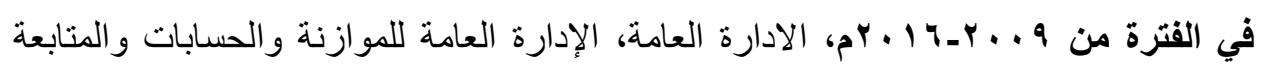
المالية، وحدة حسابات الزر اعة.

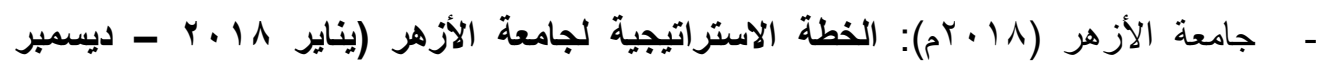
(br. rr 
إدارة أولويات برنامج الدبلوم العام في التربية بجامعة الأزهر في ضوء ملخل المقارنة المرجعية benchmarking

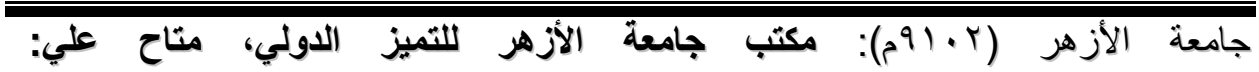

http://www.azhar.edu.eg

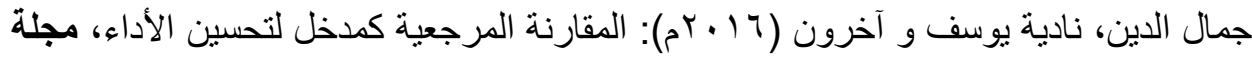

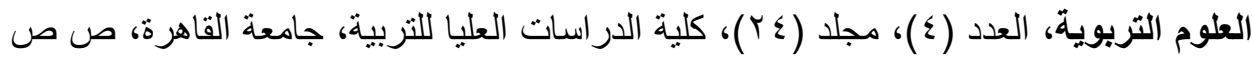
$10 \mu_{-} \mid \mu_{1}$

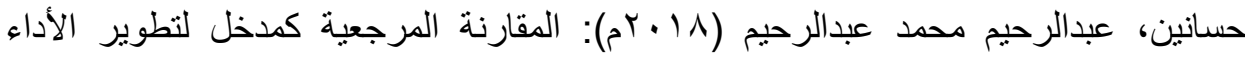
المؤسسي في المنظمات العامة- رؤية مقترحة، مجلة العلوم الاقتصادية والإدارية والقانونية،

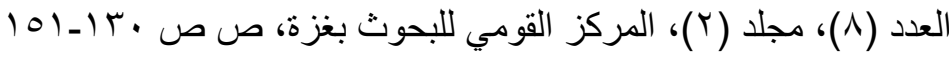

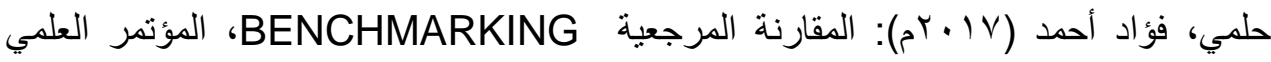
السنوي الرابع والعشرين "قيادة التعليم وإدارته في الوطن العربي ـ الواقع والرؤى المستقبلية"، المعيه

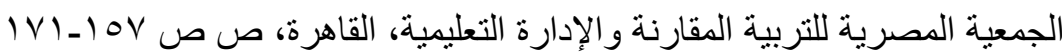
- الرشايدة، نائل سالم (9 . . rم): درجة معرفة أعضاء هيئة التدريس العاملين في جامعة مؤتة

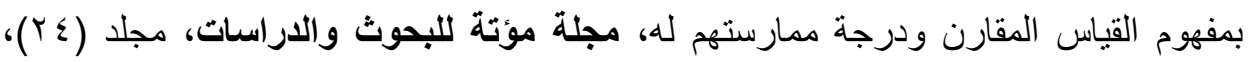

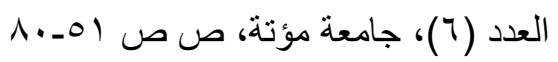

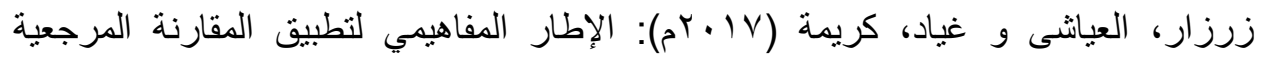

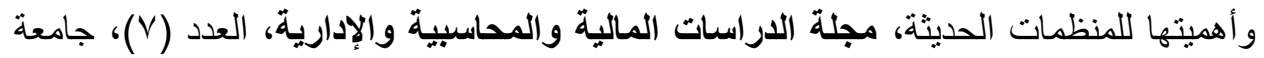

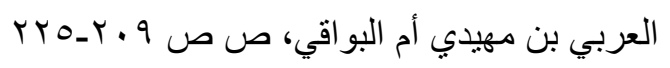
الساعدي، رحيم محمد (1 ( • rم): إصلاح التعليم في العراق وتطبيق تقنية دلفاي في الدراسات

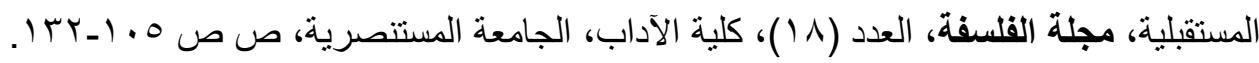

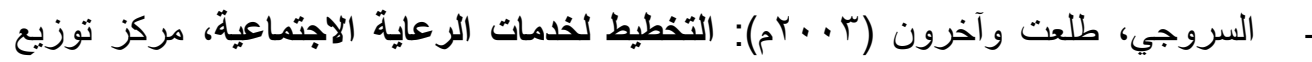
ونشر الكتاب الجامعي، جامعة حلوان. 


\section{د/ أحمد عبد الفتاح حمدي الهنداوي}

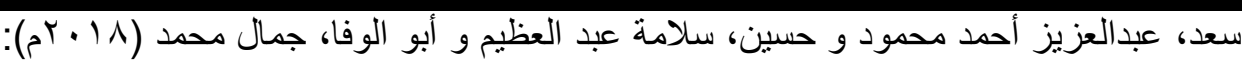
فاعلية القياس المقارن في تطوير الأداء الجامعي، مجلة كلية التربية، العدد (17) (1)، مجلد

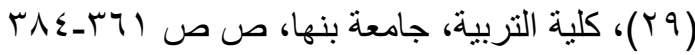
السلمي، عبداله عبد العالي نعيمان (•r.r.r): تفعيل إدارة الوقت لتجويد منظومة العمل في الإدارة الدرسية بالمملكة العربية السعودية - رؤية مستقبلية، المجلة التربوية، الجزء (• V)،

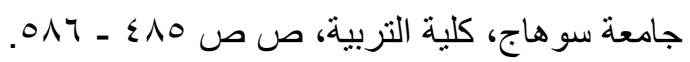

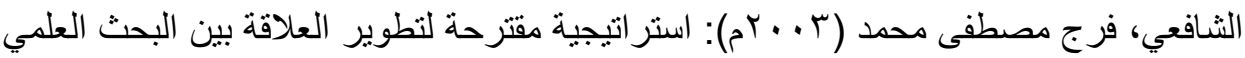
بالجامعات وبعض مؤسسات الإنتاج بصر ، رسالة دكتور اه غير منشورة، كلية التربية، جامعة الأز هر.

الثافعي، محمد محمد (· (. rم): إدارة الأولويات كأحد سبل الوقاية من الأزمات، بحث مقدم للمؤتمر السنوي الخامس لـ "إدارة الأزمات والكوارث"، كلية التجارة، جامعة عين شمس، صلإل ص

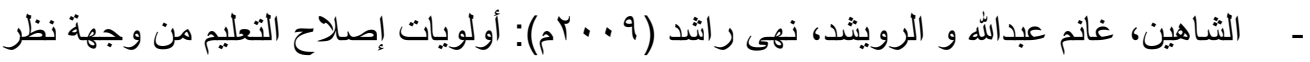
أعضاء هيئة التدريس في مؤسسات إعداد المعلم بدولة الكويت، المجلة التريوية، العدد (19)، (9)،

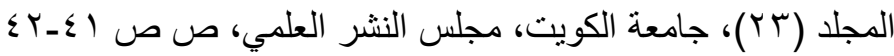
ستنفن ر. كوفي و أ. روجر ميريل، و ربييكا ر. ميريل (V . . rم): إدارة الأولويات ـ الأهم أولاً، ط

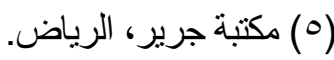
شنودة، إميل فهمي حنا (r . . rم): أسلوب القياس المقارن بالأفضل لتحقيق الجودة الثناملة في الإدارة العليا للتعليم المصري قبل الجامعي دراسة عينية، المؤتمر السنوي الحادي عشر "الجودة

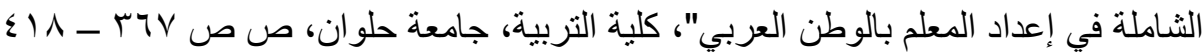
الصاوي، محمد وجيه (^ . . rم): رؤية مستقبلية لتطوير التعليم الجامعي الأزهري، بحث مقدم

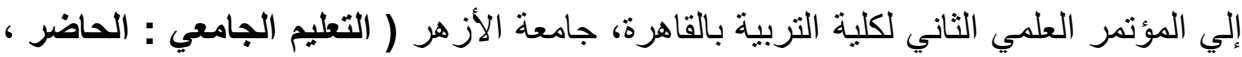

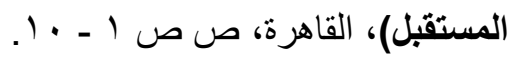

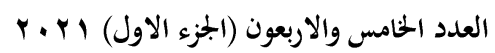

مجلة كلية التربية- جامعة عين شمس 
إدارة أولويات برنامج الدبلوم العام في التربية بجامعة الأزهر في ضوء ملخل المقارنة المرجعية benchmarking

طويجيني، زين العابدين و بوفالطة، محمد سيف الدين (·r.r.r): المقارنة المرجعية كمنهجية في تبني نظام "ل. م. د". بالجامعات الجزائرية- دراسة تحليلية، مجلة العلوم الإنسانية

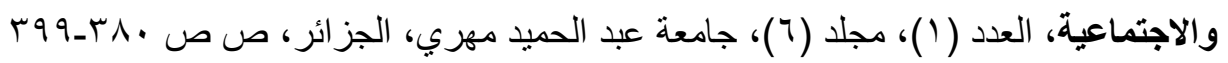

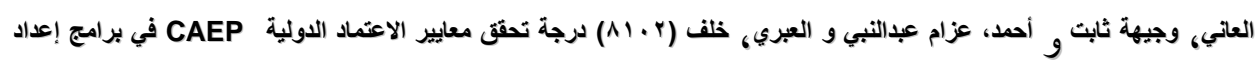

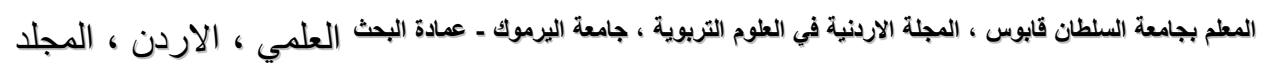

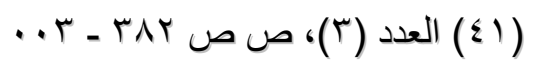

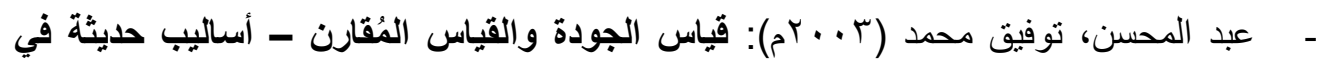
المُعايرة والقياس، دار الفكر العربي، القاهرة.

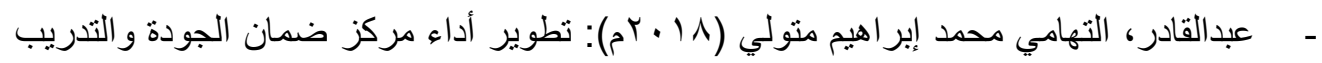

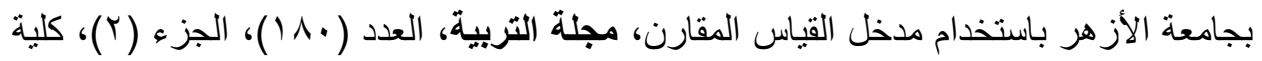

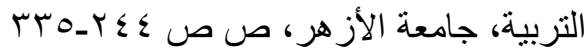

علي راشد ( (. r r): اختيار المعلم وإعداده مع دليل للتربية العملية، دار الفكرة العربي،

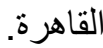

عواجي، أماني ناصر على (9 (19 م)): واقع تطبيق المقارنة المرجعية في المدارس الثانوية

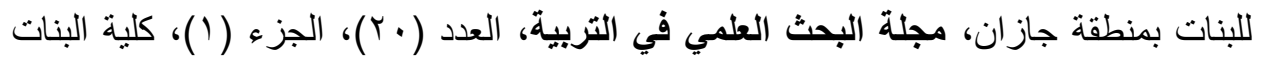

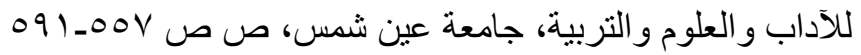

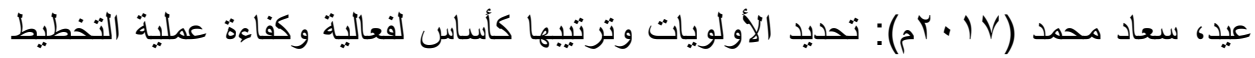

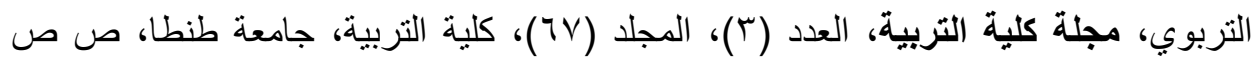
rTO - IVV

غانم، إكر ام عبد الستار محمد دياب (1) • ب): تطوير السياسة التعليمية لمعلم القرن الحادي

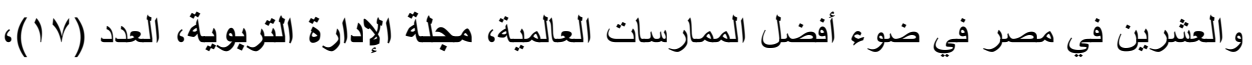

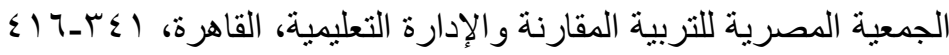




\section{د/ أحمد عبد الفتاح حمدي الهنداوي}

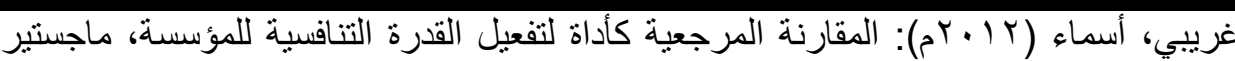
غير منشورة، كلية العلوم الاقتصادية والعلوم التجارية وعلوم التسيير، جامعة العربي بن

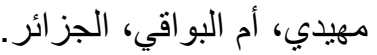

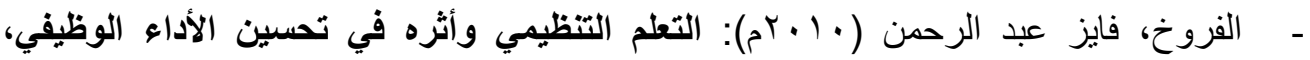
المكتبة الوطنية، المملكة الأردنبة الهاثمية

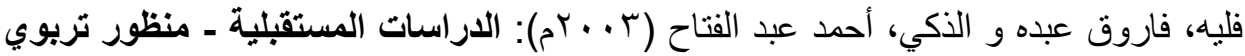

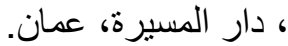

فهمي، محمد سيف الدين (ع + †) : التخطيط التعليمي - أسسه وأساليبه ومشكلاته، الطبعة الثنامنة، مكتبة الأنجلو المصرية، القاهرة.

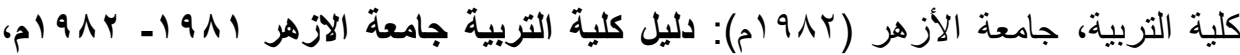

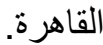
كلية التربية، جامعة الأزهر (V. . rم): اللائحة الاخلية للاراسات العليا لكليات التربية،

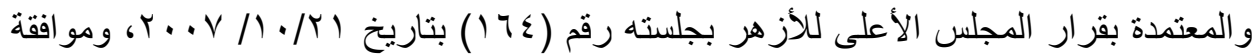

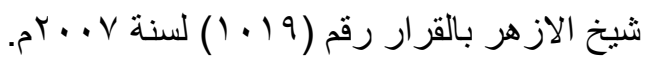

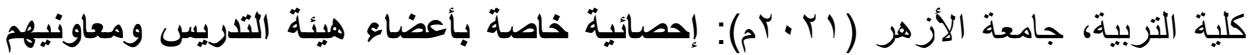

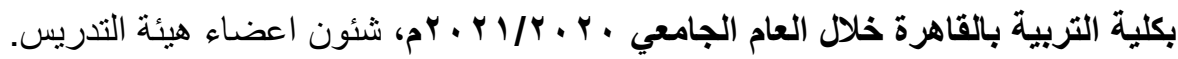
كلية التربية، جامعة الأزهر (•r.rم/ ا): الخطة الاستراتيجية لكلية التربية بنين بالقاهرة -

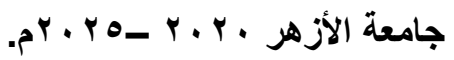

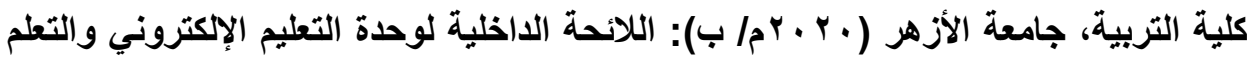
عن بعد، وحدة التعليم الإلكتروني و التعلم عن بعد. كلية التربية، جامعة الأزهر (•r.r م/ ج): إحصائية بعدد الدراسين المقيدين بمراكز التأهيل

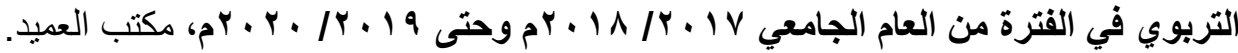


إدارة أولويات برنامج الابلوم العام في التربية بجامعة الأزهر في ضوء ملخل المقارنة المرجعية benchmarking

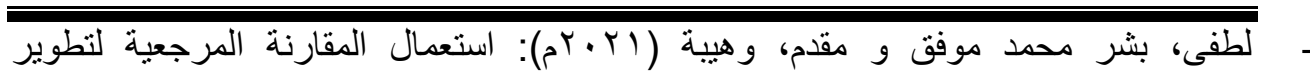
المقررات الجامعية- حالة جامعة العلوم التطبيقية مملكة البحرين، مجلة الاستراتيجية والتنمية، ولئه

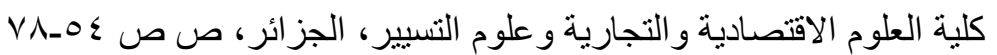
محمد، طارق إسماعيل (1 (1 • rم): نحو نموذج تخطيطي لتحديد أولويات البر امج في المؤسسات الإيوائية، المؤتمر العلمي الدولي الرابع والعشرون للخدمة الاجتماعية "الخدمة الاجتماعية

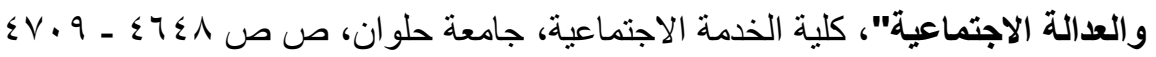

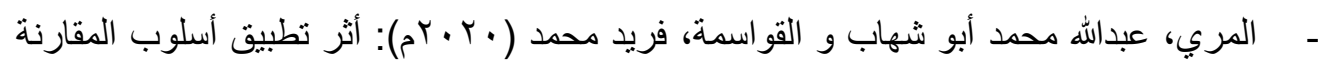

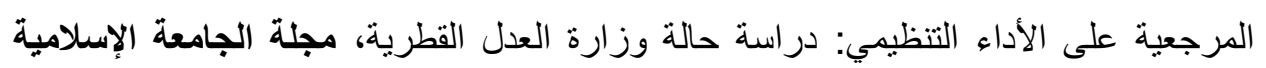

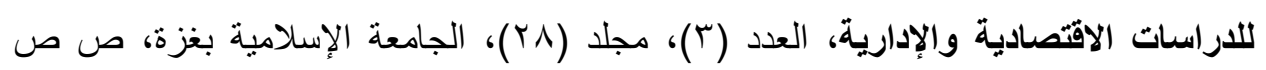
$r .0-1 V 4$

مصطفي، مجدي محمد (r.r.ra): تحديد أولويات خدمة المجتمع من منظور الخدمة الاجتماعية - دراسة تطبيقية علي مجالات التعليم والصحة والثئون الاجتماعية بمدينة العين،

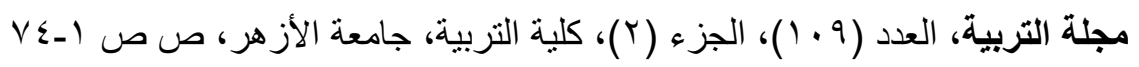

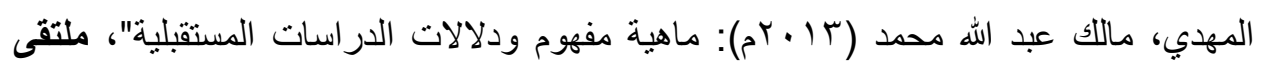

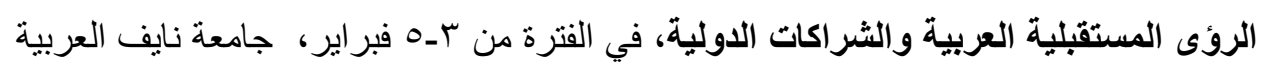

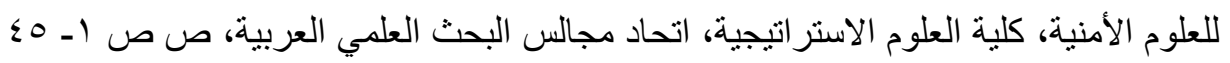

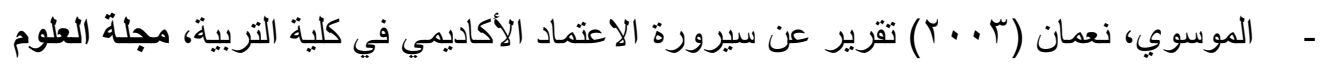

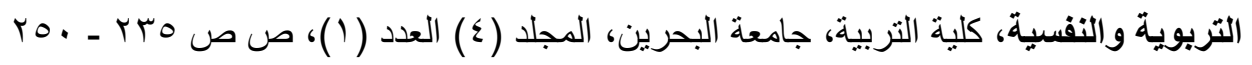

Adebanjo, Dotun\& Abbas, Ahmed and Mann, Robin (2010) , An investigation of the adoption and implementation of benchmarking, International journal of Operation and Production Management, Vol.30, No.11, PP.1140-1169 
د/ أحمد عبد الفتاح حمدي الهنداوي

- Al-Khalifa, L. (2015): Benchmarking as a means to gauge and improve academic standards in higher education within the Arab Region, The Business and Management Review, Vol. 6, No. 5, September, pp. 151-160

- CMEC (2012) Teacher Education and Development Ontario College of Teachers: Thinking About Teaching? Toronto.

- Ellinger, Anderea; Yang, Biayin; Ellinger, Alexander, 2000, Is The Learning Organization for Real Examining the Impacts of the Dimension of The Learning Organization on Organizational Performance, The Learning Organization, 8 (4), pp. 1-9.

- European Commission(2015): Education, Audiovisual and Culture Executive Agency (EACEA), Eurydice Developing key competences at school in Europe: Challenges and opportunities for policy Eurydice Report. Luxembourg: Publications Office of the European Union. Retrieved Sep. 28, 2015 from: http://eacea.ec.europa.eu/education/eurydice,documents/thematic _reports/145EN.pdf

- Garvin, David, (1993): Building a Learning Organization, Harvard Business Review 1 71, Issue (4), pp. 78- 92

- Interstate New Teacher Assessment and Support Consortium (2019) Retrieved June 20, 2019 from: http: / / www. ccsso. org.

- Jackson, N \& Lund, H (2000): benchmarking for Higher Education, Society for Research in Higher Education, Open University Press, London. 
إدارة أولويات برنامج الدبلوم العام في التربية بجامعة الأزهر في ضوء مدخل المقارنة المرجعية benchmarking

- Jussila, J., \& Saari, S (2000) Teacher education as a futuremolding factor: International evaluation of teacher education in Finnish universities. Helsinki: Higher Education Evaluation Council.

- KLEINER , OWEN OU AND BRIAN H.(2015), Excellence in benchmarking, Industrial Management Journal, NovemberDecember, 20-24

- McClure, Ann Elizabeth (2008) Teacher evaluation: Pre-service to in-service, A thesis Submitted in Conformity with the Requirements for Degree of Doctor of Philosophy, Department of Curriculum, teaching and Learning, University of Toronto: Ontario Institute for Studies in Education.

- Ministry of Education - Canada (2015): New Ontario Teacher Preparation Program, Canada.

- Ministry of Education - Canada (2017): Strategic Plan for Education entitled Achieving Excellence, A Renewed Vision for Education in Canada

- Ministry of Education - China (2015): Initiative of the Advisory Committee on Teacher Training and Competency in the State of Hong Kong, China.

- Ministry of Education - Singapore (2015): Strengthening Performance Management Program, Singapore. 
د/ أحمد عبد الفتاح حمدي الهنداوي

- Ministry of Education - Singapore (2017): National Institute of Education Singapore: 21st Century Teacher Education Program.

- Mullis, Ina VS, et al (2012) PIRLS 2011 International Results in Reading. International Association for the Evaluation of Educational Achievement, Amsterdam, The Netherlands.

- National Council for Accreditation of Teacher Education (2002) Professional Standards for the Accreditation of School, Washington: Colleges and Departments of Education., DC.

- NCATE (2008). Professional Standards for the Accreditation of Teacher Preparation Institutions. http://www.ncate.org/institutions/publicationsbooks.asp?ch=49\&bo ok=standards

- Nevis, Edwin C; Dibella, AnthonyJ; Gould, Janet M, 1995, Understanding Organizations as Learning Systems, Sloan Management Review,(winter), pp. 73-85.

- Odora, Ronald James (2014): The Effectiveness of Benchmarking as a Organizational Transformation Strategy in Higher Education institutions in South Africa, Mediterranean Journal of Social Sciences, Vol (5), No (1), MCSER Publishing, Rome-Italy, pp 521-529

- OECD (2013a): PISA, Publishing. Available at: http://dx.doi.org/10.1787/9789264201156-en.

- OECD (2013b) Teachers for the 21st century: Using evaluation to improve teaching. OECD Publishing, Paris. 
إدارة أولويات برنامج الدبلوم العام في التربية بجامعة الأزهر في ضوء مدخل المقارنة المرجعية benchmarking

OECD (2015): Teaching and Learning International survey, (TALIS).

- Sahlberg, P. (2010a) The Secret to Finland's Success: Educating Teachers. Stanford, CA: Stanford Center for Opportunity Policy in Education.

- Sahlberg, P. (2010b) Educational change in Finland. In A. Hargreaves, A Lieberman, M. Fullan \& D. Hopkins (Eds.), Second International Handbook of Educational Change (pp. 323- 328). New York, NY: Springer.

- Westbury, I., Hansen, S-E., Kansanen, P., \& Björkvist, O. (2005) Teacher education for research-based practice in expanded roles: Finland's experience. Scandinavian Journal of Educational Research, 49(5).

- Woodhouse, D \& Stella, A (2006): Human Resources benchmarking in AUQA, Audit Reports HR benchmarking Conference, Melbourne, 3 November, 2006 